\title{
Recent synthetic applications of the dealkoxycarbonylation reaction. Part 2. Dealkoxycarbonylations of $\beta$-keto esters, $\alpha$-cyanoesters and related analogues
}

\author{
A. Paul Krapcho \\ Department of Chemistry, University of Vermont, Burlington, VT 05405 USA \\ E-mail: A.Paul.Krapcho@,uvm.edu
}

\begin{abstract}
In Part 2, the synthetic applications of dealkoxycarbonylations of $\beta$-keto esters, $\alpha$ - cyano esters and related activated esters will be reviewed for the period 1981 to the middle of 2006. In Part 1, the dealkoxycarbonylations of malonate esters were reviewed for this same period.
\end{abstract}

Keywords: Dealkoxycarbonylations, decarbalkoxylations, Krapcho, $\beta$-keto esters, $\alpha$-cyano esters, activated esters

\section{Contents}

1. Introduction

2. Ketones

2.1. From monosubstituted $\beta$-keto esters

2.1.1. Water alone

2.1.2. Water-salts

2.1.2.1. From alkyl, aryl, heterocyclic and heteroaryl substituted open chain substrates

2.1.2.2. From fluoro substituted substrates

2.1.2.3. From carbocylic $\beta$-keto esters

2.1.2.4. From heterocyclic $\beta$-keto esters

2.1.2.5. From an $\alpha, \alpha$-dicarbethoxy ketone

2.2. Disubstituted $\beta$-keto esters

2.2.1. Water alone

2.2.2. Water-salts

2.2.2.1. Open chain substitutents

2.2.2.2. From carbocyclic $\beta$-keto esters

2.2.2.2.3. Water-salts

2.3. Heterocyclic substrates 
2.3.1. From $\beta$-carbethoxy substituted lactones

2.4. 1,3-Diones

2.4.1. From substituted 2-carbalkoxy-1,3-diones

2.5. 1,4-Diones

2.5.1. From $\alpha$-carbalkoxy-1,4-diones

2.6. 1,5-Dione

2.6.1. From $\alpha$-carbomethoxy substituted substrate

2.7. $\beta$-Keto ester and malonate ester polyfunctional substrates

2.8. Aldehyde

2.8.1. From $\alpha$-methoxycarbonyl aldehyde

2.9. Nitriles

2.9.1. From $\alpha$-cyano esters

2.9.2. From mono substituted substrates

2.9.3. From disubstituted substrates

2.10. Sulfones

2.10.1. From $\alpha$-sulfonyl esters

2.11. Sulfoximines

2.11.1. From $\alpha$-carbomethoxy sulphoximines

2.12. Chiral phosphine oxides

2.12.1. From P-chiral phosphinyl acetates

2.13. Ketophosphonates

2.13.1. From 2-acylphosphonoacetates

2.14. Nitro analogues

2.14.1. From $\alpha$-nitro esters

2.15. 2-Cyclohexenone derivatives

2.15.1. From 4-Carbalkoxy-2-cyclohexenones

2.16. Heterocyclic vinylogous deethoxycarbonylation

2.17. Tetra-demethoxycarbonylation

3. Conclusions

4. References

\section{Introduction}

In Part 1, the synthetic applications of the dealkoxycarbonylations of malonate esters were presented. In Part 2, the synthetic applications of the dealkoxycarbonylations of $\beta$-keto esters, $\alpha$ cyano esters and related activated ester derivatives will be illustrated with selected examples. The literature search covers the period 1981 throught mid 2006 and complements our prior review. ${ }^{1}$ 


\section{Ketones}

\subsection{From monosubstituted $\beta$-keto esters}

\subsubsection{Water alone}

As noted in our previous review, ${ }^{1}$ dealkoxycarbonylations of mono substituted $\beta$-keto esters (or the corresponding enols) can be effected on heating in DMSO and water without the addition of salts. Additional examples of this methodology have been reported.

Treatment of cis-1a $(\mathrm{n}=1)$ with DMSO and water $\left(150^{\circ} \mathrm{C}, 15 \mathrm{~h}\right)$ led to cis-2a $(68 \%, \mathrm{n}=$ $1)$, the product from the decarbomethoxylation of the $\beta$-keto ester moiety. Analogue cis-1b $(\mathrm{n}=$ $2)$ in DMSO and water $\left(140^{\circ} \mathrm{C}, 2 \mathrm{~h}\right)$ afforded cis- $\mathbf{2 b}(80 \%){ }^{2}$
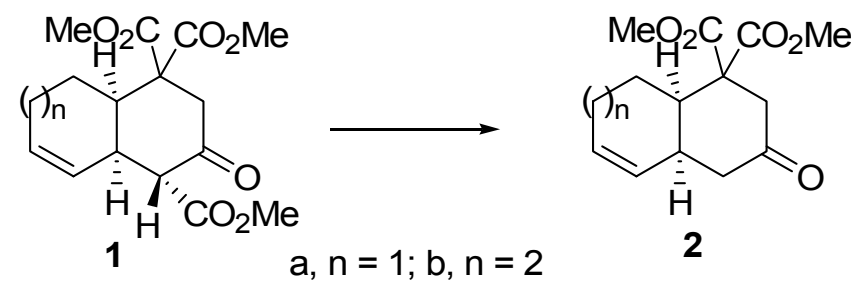

In routes to several sex pheromones of the peach fruit moth and the Douglas fir tussock moth, decarbomethoxylations of several long chain $\beta$-keto esters were investigated. Treatment of $\mathbf{3 a}, \mathbf{b}, \mathbf{c}$ with DMSO and water $\left(150^{\circ} \mathrm{C}, 3.5 \mathrm{~h}\right)$ led to the products $\mathbf{4 a , b , c}$ in yields of $80 \%{ }^{3}$

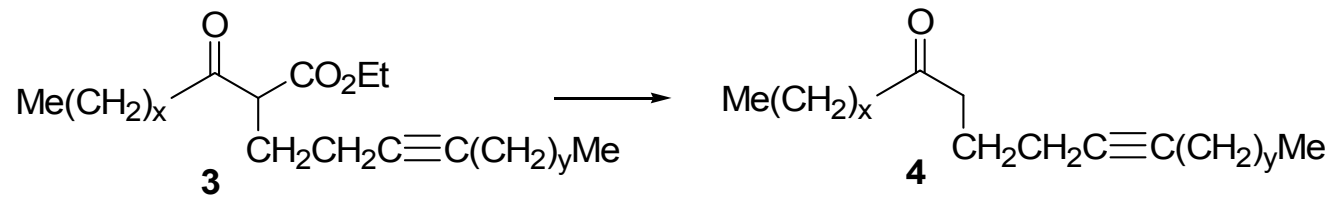

$$
a, x=7, y=5 ; b, x=8, y=5 ; c, x=9, y=4
$$

Brief microwave irradiation of mono-alkylated $\beta$-ketoesters at $160-200{ }^{\circ} \mathrm{C}$ in wet $\mathrm{DMF}$ induced smooth and selective decarboalkoxylations. For example, treatment of $\mathbf{5}$ with DMSO and water $\left(160^{\circ} \mathrm{C}, 3 \mathrm{~min}\right)$ under microwave irradiation led to $6(89 \%){ }^{4}$

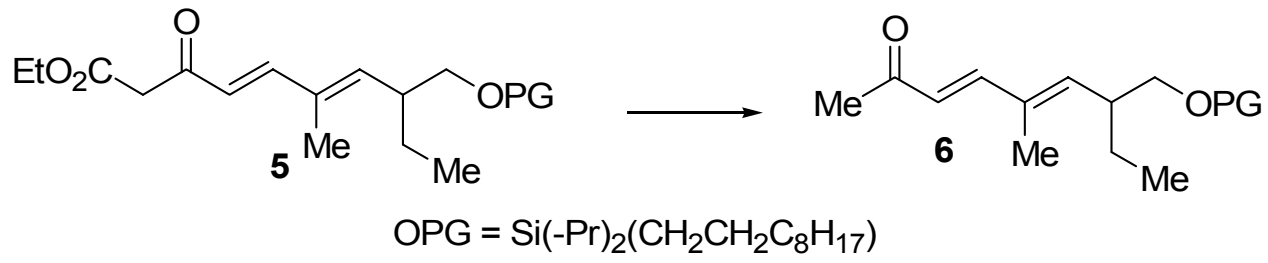

The deethoxycarbonylation of 7a,b in wet DMSO (reflux, 4 h) afforded $\mathbf{8 a}(44 \%)$ or $\mathbf{8 b}$ $(66 \%)$, respectively. ${ }^{5}$ 
<smiles>[R]C(O)=C(C(=O)OCC)C(F)(F)F</smiles><smiles></smiles>

a, $\mathrm{R}=\mathrm{CH}_{3}(44 \%) \quad 8$

b, $\mathrm{R}=\mathrm{C}_{6} \mathrm{H}_{5}(66 \%)$

The demethoxycarbonylation of enantiomer 9 in DMSO and water $\left(155^{\circ} \mathrm{C}, 2.5 \mathrm{~h}\right)$ led to the enantiomeric tricycle $\mathbf{1 0}(92 \%){ }^{6}$<smiles>COC(=O)C1=C(O)C(C)(C)C2C=CC3C[C@@H](C#N)CC3(C=O)[C@]2(C)C1</smiles><smiles>CC1(C)C(=O)CC[C@@]2(C)[C@@H]1C=C[C@@H]1C[C@@H](C#N)C[C@]12C=O</smiles>

\subsubsection{Water-salts}

2.1.2.1. From alkyl, aryl, heterocyclic and heteroaryl substituted open chain substrates. A number of optically active acetoacetates were alkylated on a solid support $\left(\mathrm{Al}_{2} \mathrm{O}_{3}, t-\mathrm{BuOH}\right)$ with alkyl bromides and the products subjected to dealkoxycarbonylations using $\mathrm{LiCl}$ in DMSO. For example, derivative 11 led to 12 with an optical purity of $13 \%$ ( $S$-configuration). ${ }^{7}$<smiles>CCCCCC(C)C</smiles>

11<smiles>CCCCCC(C)CC(C)=O</smiles>

12

Keto ester 13 on treatment with DMSO, $\mathrm{NaCl}$ and water $\left(70^{\circ} \mathrm{C}, 12 \mathrm{~h}\right)$ led to $(+)-\mathbf{1 4}$ in good yield. This intermediate was easily converted into the alkaloid (+)-pinidine. ${ }^{8}$<smiles>CC(=O)CCCC=CC(C)C(C)C</smiles>

The $\beta$-keto ester 15 on heating in $\mathrm{DMF}, \mathrm{NaCl}$ and water (reflux, $72 \mathrm{~h}$ ) led to $\mathbf{1 6}(88 \%)$, which was converted into a octahydropyridopyrrolizine-2-(1H)-one. ${ }^{9}$ 
<smiles>CCOCCCCC(=O)CCCC(=O)CCCC(=O)OCC</smiles>

The decarbomethoxylation of 17 using DMSO, $\mathrm{LiCl}$ and water (reflux, $10 \mathrm{~min}$ ) led to the $\mathrm{C}-2$ symmetrical ketone 18 (94\%). This intermediate could be readily transformed into the corresponding enantiomeric spiroketal on treatment with aqueous acetic acid. ${ }^{10}$<smiles>CO[C@H](CCC1OCC(C)(C)O1)C(=O)CCC[C@H]1OCC(C)(C)O1</smiles>

17

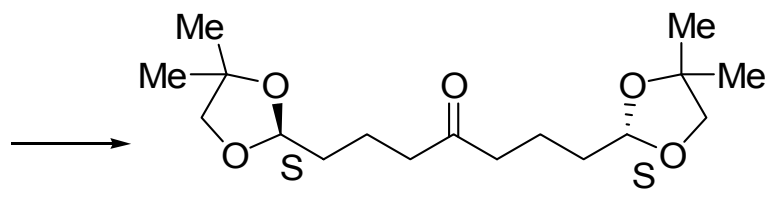

18

The decarbomethoxylation of 19 with $\mathrm{DMSO}, \mathrm{LiCl}$, and water $\left(190^{\circ} \mathrm{C}, 40 \mathrm{~min}\right)$ provided the $\mathrm{C}_{2}$-symmetric ketone $20(3 E, 5 S, 9 S, 10 E)(96 \%)$. This ketone on asymmetric syn- dihydroxylation and acid catalysis led to a mixture of dioxaspiro[5,5]undecane and dioaxospiro[4,5]decane. ${ }^{11}$<smiles>CCOC(=O)C(C(=O)C[C@@H](C)/C=C/CCOCc1ccccc1)[C@@H](C)/C=C/CCOCc1ccccc1</smiles>

A number of $\omega$-alkenyl ketones have been prepared by deethoxycarbonylation of the appropriate $\beta$-keto esters. For example, treatment of 21 with $\mathrm{DMF}$ and $\mathrm{LiBr}\left(195-200^{\circ} \mathrm{C}, 3 \mathrm{~d}\right)$ led to $22(67 \%){ }^{12}$<smiles>C=CCCC(=O)c1ccc(C)cc1</smiles>

Treatment of $\mathbf{2 3}$ (isomeric mixture ) with DMSO, $\mathrm{NaCN}\left(90^{\circ} \mathrm{C}, 22 \mathrm{~h}\right)$ led to $\mathbf{2 4}(70 \%)$ as an isomeric mixture. This intermediate was used in the synthesis of estrone derivatives. ${ }^{13}$ 


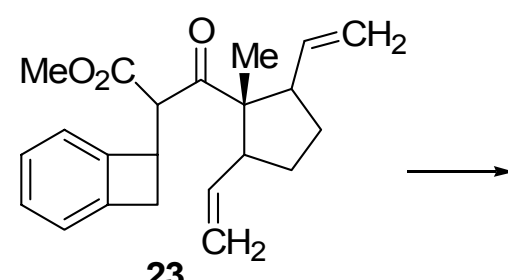

23

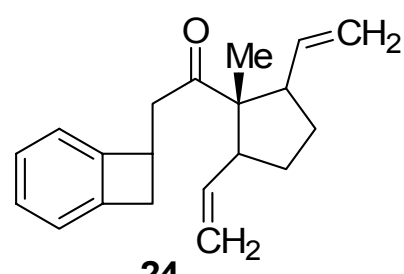

24

The deethoxycarbonylation of $\mathbf{2 5}$ was accomplished using DMSO, $\mathrm{LiCl}$ and water $\left(160^{\circ} \mathrm{C}\right.$, $24 \mathrm{~h})$ to yield $26(83 \%)$. This was converted into an acerogenin-type diaryl heptanoid holding an endocyclic biaryl ether bond. ${ }^{14}$<smiles>CCOC(=O)C(CCCc1ccc(F)c([N+](=O)[O-])c1)C(=O)CCc1ccc(OC)c(OC(C)C)c1</smiles>

The chemoselective demethoxycarbonylation of the $\beta$-keto ester $\mathbf{2 7}$ was accomplished by treatment with DMSO, $\mathrm{NaCl}$ and water $\left(125^{\circ} \mathrm{C}, 24 \mathrm{~h}\right)$ to afford optically active $28(78 \%)$, which in a subsequent series of steps could be converted into (-)-virantmycin. ${ }^{15}$

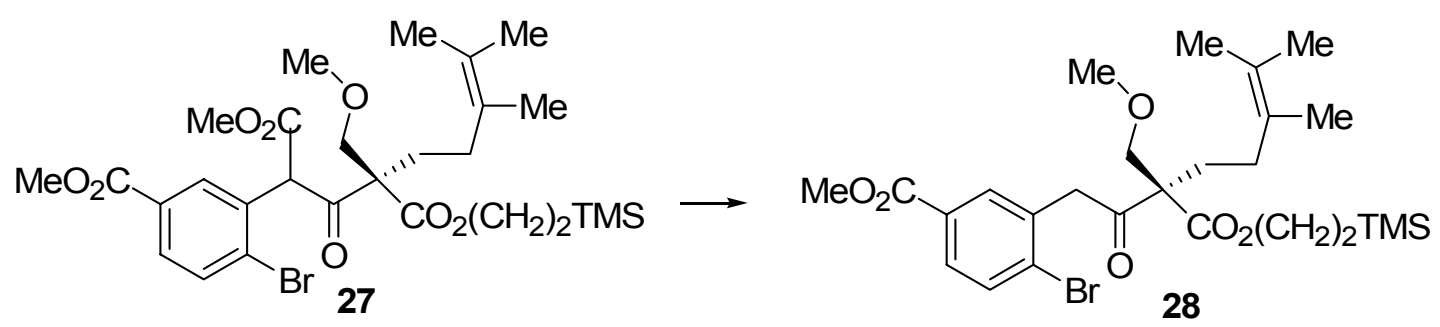

In a pathway to racemic chrysolic acid, the deethoxycarbonylation of 29 with DMSO, $\mathrm{NaCN}$ and water $\left(140-150^{\circ} \mathrm{C}, 10 \mathrm{~h}\right)$ led to intermediate $\mathbf{3 0}(60 \%) .{ }^{16}$<smiles>CCOC(C)C(Cc1cc2c(c(C)c1C)CCCC2(C)C)C(C)=O</smiles><smiles>CC(=O)CCc1cc2c(c(C)c1C)CCCC2(C)C</smiles>

Treatment of 31 with DMSO, $\mathrm{NaCl}$ and water $\left(135^{\circ} \mathrm{C}, 8 \mathrm{~h}\right)$ led to $32(82 \%)$, isolated as the $\mathrm{HCl}$ salt. ${ }^{17}$ 


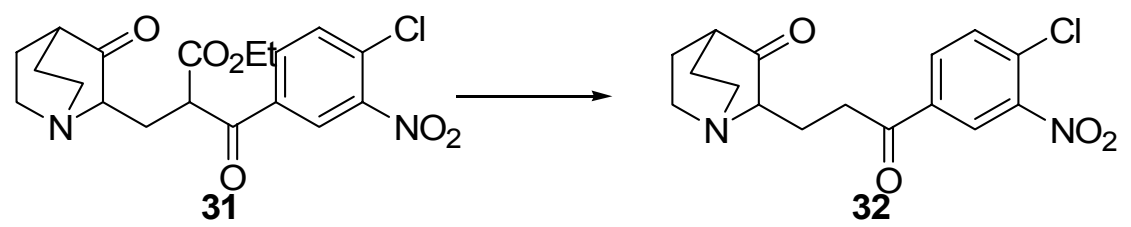

Treatment of keto ester 33 with $\mathrm{DMSO}, \mathrm{NaCl}$ and water $\left(150^{\circ} \mathrm{C}, 2 \mathrm{~h}\right)$ led to ketone 34(70\%). ${ }^{18}$<smiles>COC(=O)C(C(=O)c1cnccc1CCCOC(C)(C)C)c1ccccc1</smiles><smiles>CCCCOCCCc1ccncc1C(=O)Cc1ccccc1</smiles>

The enantiomeric $\beta$-keto ester 35 on treatment with $\mathrm{DMF}, \mathrm{NaCl}$ and water (reflux, $9 \mathrm{~h}$ ) led to the de-t-butoxycarbonylated pyrrolidine 36-(3R) (92\%). The stability of the BOC group under the reaction conditions is of particular note. ${ }^{19}$<smiles></smiles>

35

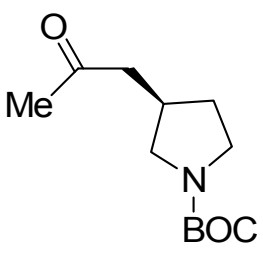

36

Treatment of $\beta$-keto ester 37 with DMSO, $\mathrm{NaCl}$ and water $\left(135^{\circ} \mathrm{C}, 2 \mathrm{~h}\right)$ led to $38(80 \%)$. This intermediate was converted into 1,6-dideoxynojirimycin ( a polyhydroxy piperidine) in a series of subsequent steps. ${ }^{20}$
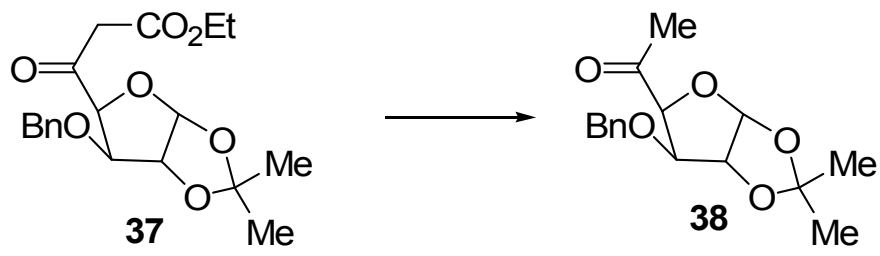

A mixture of enol 39 and the corresponding $\beta$-keto ester in DMSO, $\mathrm{NaCl}$ and water (150$160^{\circ} \mathrm{C}, 5 \mathrm{~h}$ ) afforded the flavanoid $40(89 \%){ }^{21}$<smiles>CC(=O)C1=C(O)c2ccccc2OC1c1ccccc1</smiles>

39<smiles>O=C1CC(c2ccccc2)Oc2ccccc21</smiles>

40 
The deethoxycarbonylation of $\mathbf{4 1}$ was accomplished by heating in $\mathrm{DMSO}, \mathrm{NaCl}$ and water $\left(150-160^{\circ} \mathrm{C}, 8 \mathrm{~h}\right)$ to afford $42(42 \%){ }^{22}$<smiles>CCOC(=O)C(C(=O)c1ccccc1)C1c2ccccc2COc2ccccc21</smiles>

41

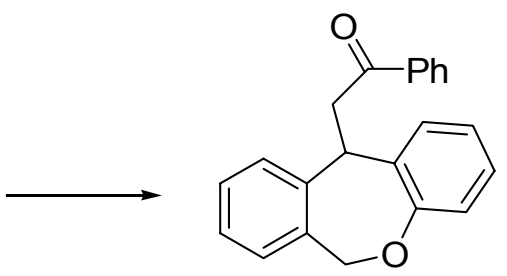

42

The synthesis of (-)-secodaphniphylline (44) (44\%, 99.6\% ee) has been accomplished by heating $\beta$-keto ester 43 with $\mathrm{NaCN}$ in DMSO containing a few drops of water $\left(150^{\circ} \mathrm{C}, 2 \mathrm{~h}\right) .^{23}$

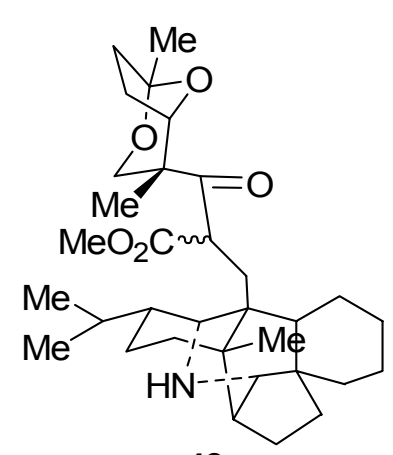

43

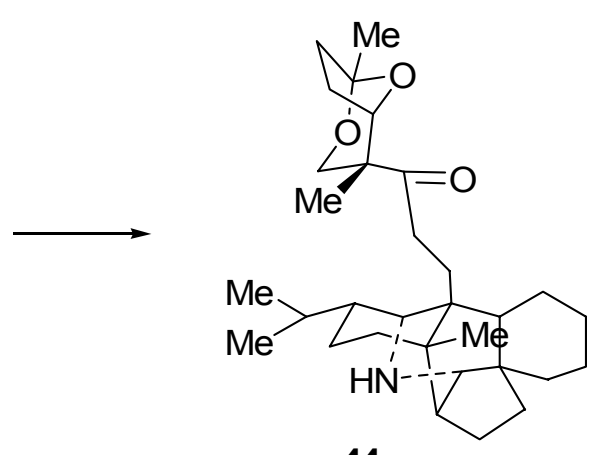

44

Treatment of 45 ( and the enol tautomer) with $\mathrm{DMSO}, \mathrm{NaCl}$ and water $\left(150^{\circ} \mathrm{C}, 5 \mathrm{~h}\right)$ led to the ethyl thiazole-5-carboxylate $46(47 \%) .^{24}$<smiles>CCOC(=O)c1sc(N)nc1SC(C(C)=O)C(=O)OCC</smiles><smiles>CCOC(=O)c1sc(N)nc1SCC(C)=O</smiles>

2.1.2.2. From fluoro substituted substrates. In a general method for the preparation of trifluoromethyl ketones, derivatives 47 on treatment with DMF, LiCl and water (reflux, $2 \mathrm{~h}$ ) led to the ketones 48 (38-90\%). ${ }^{25 a, b}$<smiles></smiles>

$$
\mathrm{R}=\text { n-octyl, benzyl, } \mathrm{CH}_{2} \mathrm{CH}_{2} \mathrm{Ph}, \mathrm{C}_{6} \mathrm{H}_{5} \mathrm{CH}=\mathrm{CHCH}_{2}
$$


Treatment of 49 with $\mathrm{DMSO}, \mathrm{NaCl}$ and water $\left(150-160^{\circ} \mathrm{C}, 15 \mathrm{~min}\right)$ led to the loss of a methoxycarbonyl group to afford the fluoro keto ester $\mathbf{5 0}(32 \%){ }^{26}$<smiles>COC(=O)C(F)C(=O)C(C)(C)C</smiles>

2.1.2.3. From carbocylic $\boldsymbol{\beta}$-keto esters. The $\beta$-keto ester $\mathbf{5 1}$ on treatment in DMF with LiI (reflux, 2 h) led to $\mathbf{5 2}(76 \%)$, an intermediate used in an attempted approach to the sesquiterpene quadrone. $^{27}$

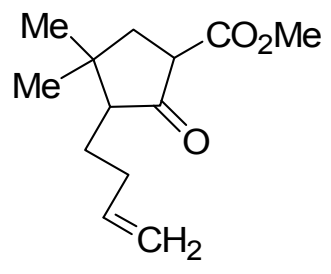

51

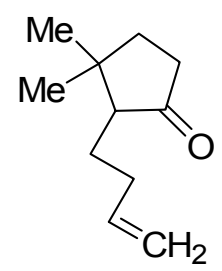

52

A mixture of 53a and 53b was treated with DMSO, $\mathrm{LiCl}$ and water $\left(120-130^{\circ} \mathrm{C}, 3 \mathrm{~h}\right)$ to afford a mixture of optically active $\mathbf{5 4 a}$ and $\mathbf{5 4 b}(64 \%$, ratio $2.45: 1){ }^{28}$

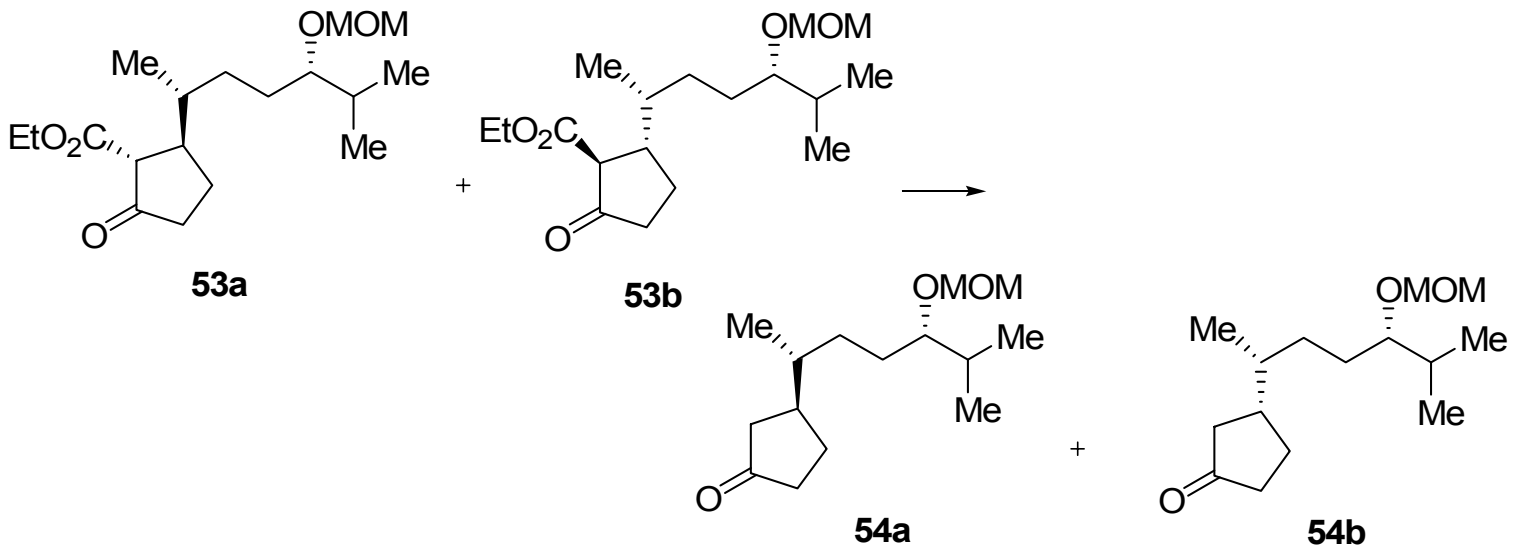

Treatment of chiral 55 with DMSO and NaI $\left(100^{\circ} \mathrm{C}, 3 \mathrm{~h}\right)$ led to the (-)-56 (3S, 4S) (89\%). This intermediate was subsequented converted into cuparene, laurene, $(-)-\alpha-$ and $(+)-\beta-$ cuparenones. $^{29}$ 

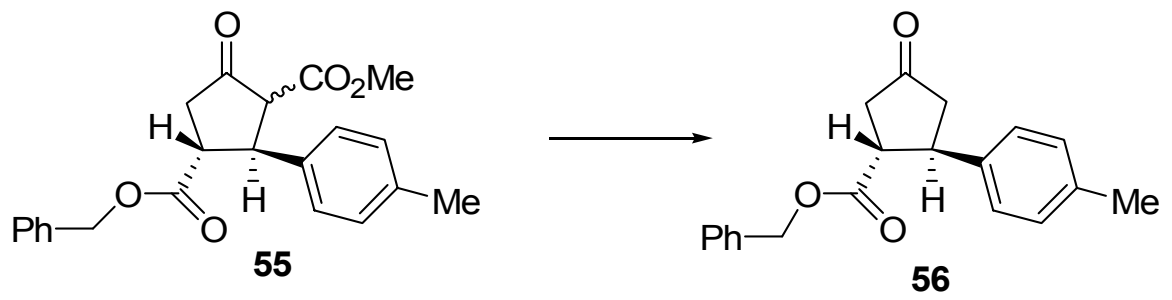

The synthesis of (+)-58 (69\%) was accomplished by heating 57 in DMSO, $\mathrm{NaCl}$ and water $\left(165^{\circ} \mathrm{C}, 45 \mathrm{~min}\right)$. This intermediate was converted into (+)-estrone methyl ether. ${ }^{30}$

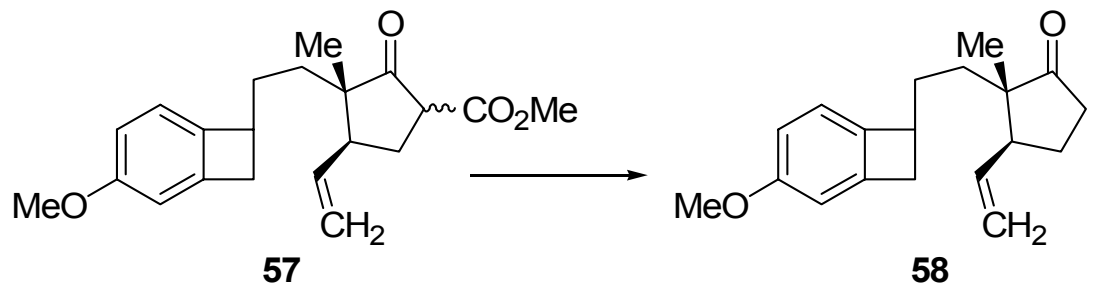

Upon heating $\beta$-keto ester 59 in DMSO, $\mathrm{LiCl}$ and water $\left(190^{\circ} \mathrm{C}, 2 \mathrm{~h}\right)$, the $\alpha, \beta$-unsaturated ketone $60(73 \%)$ was obtained. This intermediate was subsequently transformed into cisjasmone. $^{31}$<smiles>CCC#CCC1=CCCC1=O</smiles>

59

60

The bis-silylated keto ester $\mathbf{6 1}$ on treatment with $\mathrm{DMSO}, \mathrm{NaCl}$ and water $\left(130-150^{\circ}, 3 \mathrm{~h}\right)$ led to the decarbomethoxylated product $\mathbf{6 2}(86 \%) .{ }^{32}$

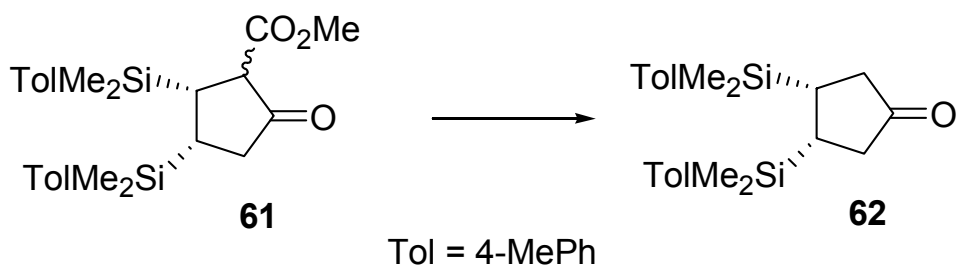

Treatment of rac-63 with DMSO, $\mathrm{LiCl}$ and water (reflux, $5 \mathrm{~h}$ ) led to rac-64 (40\%) which was used in a synthesis of (-)-norgestrel. ${ }^{33}$ 

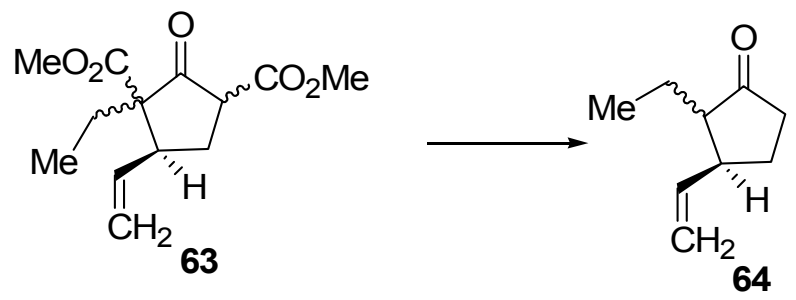

Treatment of 65 with DMSO, $\mathrm{NaCl}$ and water (reflux, $5 \mathrm{~h}$ ) led to a mixture of 66a:66b $(69 \%){ }^{34}$<smiles>COC(=O)[C@@H]1C(=O)C[C@@H]2CC(=O)C[C@@H]2[C@@H]1OC</smiles>

65<smiles>CC1C(=O)C[C@H]2CC(=O)C[C@H]1[C@H]2[NH3+]</smiles>

$66 a$<smiles>CC(C)(C)[C@H]1C(=O)C[C@@H]2CC(=O)C[C@H]21</smiles>

66b

Treatment of 67 with $\mathrm{DMSO}, \mathrm{LiCl}$ and water $\left(145^{\circ} \mathrm{C}\right.$, quickly to room temperature) led to racemic 68 (96\%) which was used in a synthesis of racemic silphinene. ${ }^{35}$

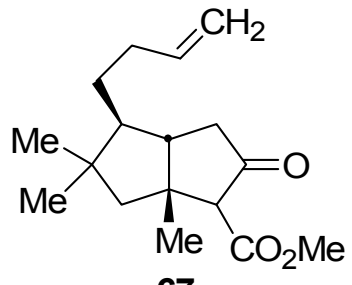

67

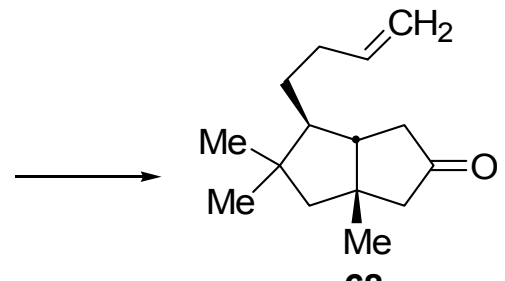

68

Treatment of 69 with DMSO, $\mathrm{NaCl}$ and water $\left(150^{\circ} \mathrm{C}, 6 \mathrm{~h}\right)$ afforded (-)-70 (86\%) which in a series of steps could be converted into $(+)$-capnellene. ${ }^{36}$

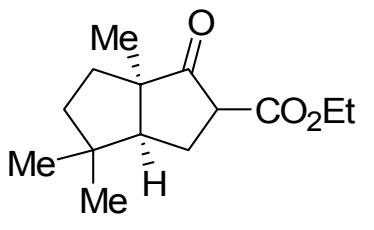

69

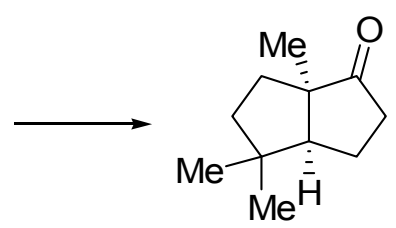

70

Treatment of enolic triester 71 with DMSO, $\mathrm{NaCl}$ and water $\left(140^{\circ} \mathrm{C}, 2 \mathrm{~h}\right)$ led to keto diester $72(92 \%)$. This was used as an intermediate in the synthesis of tricyclo octane structure. ${ }^{37}$<smiles></smiles>

71

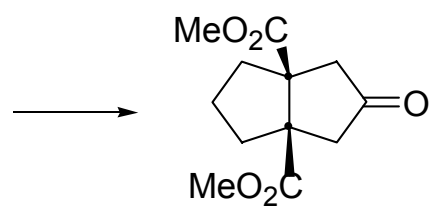

72 
The demethoxycarbonylation of $\mathbf{7 3}$ was accomplished by heating in $\mathrm{DMSO}, \mathrm{NaCl}$ and water $\left(85^{\circ} \mathrm{C}, 19 \mathrm{~h}\right)$ to afford racemic $74(62 \%)$. This was subsequently converted into the cedrenoid sesquiterpenes racemic $\alpha$-biotol and $\beta$-biotol. ${ }^{37 a}$ Other similar conversions have also been reported. $^{38 b, c}$

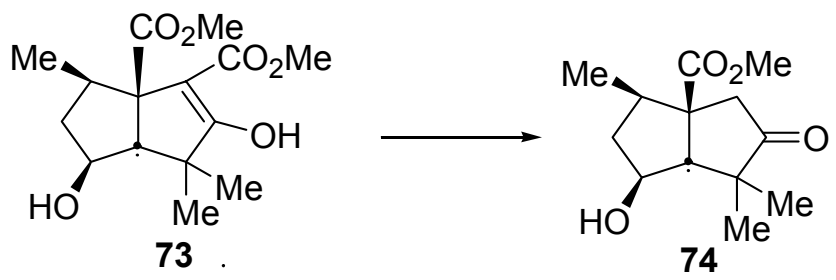

Enantiomerically pure 75 on treatment with DMSO and water $\left(155^{\circ} \mathrm{C}, 2.5 \mathrm{~h}\right)$ led to the deethoxycarbonylated ketone $76(1 R, 6 R)(92 \%)$. Attempts to convert this ketone into $(+)-$ papuamine, a pentacyclic alkaloid isolated from a sponge, were not successful. ${ }^{39}$<smiles>CCOC(=O)[C@H]1C(=O)C[C@@H]2CC=CC[C@H]21</smiles>

75<smiles>O=C1CC2CC=CC[C@H]2C1</smiles>

76

Treatment of 77 with DMSO, $\mathrm{LiCl}$ and water $\left(120-140^{\circ} \mathrm{C}, 2 \mathrm{~h}\right)$ led to $(3 \mathrm{aR}, 7 a R)-78(91 \%)$. This ketone was subsequently converted into $(+)$-grindelic acid in a 10 -step sequence. ${ }^{40}$
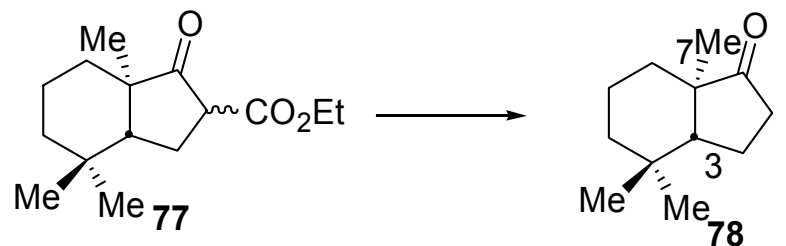

The dealkoxycarbonylation of 79 using DMSO, $\mathrm{LiCl}$ and water (reflux, $30 \mathrm{~min}$ ) led to the removal of the protective group with formation of the keto diol $\mathbf{8 0}(78 \%){ }^{41}$

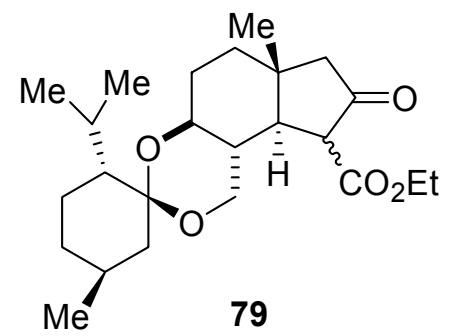<smiles>CC12CC[C@@H](O)[C@@H](CO)[C@@H]1CC(=O)C2</smiles> 
Treatment of 81 with $\mathrm{N}$-methylpyrrolidone, $\mathrm{LiCl}$ and water $\left(120-125^{\circ} \mathrm{C}, 6 \mathrm{~h}\right)$ led to $82(70 \%)$, used in a synthesis of racemic strigol, a seed germination stimulant. ${ }^{42}$
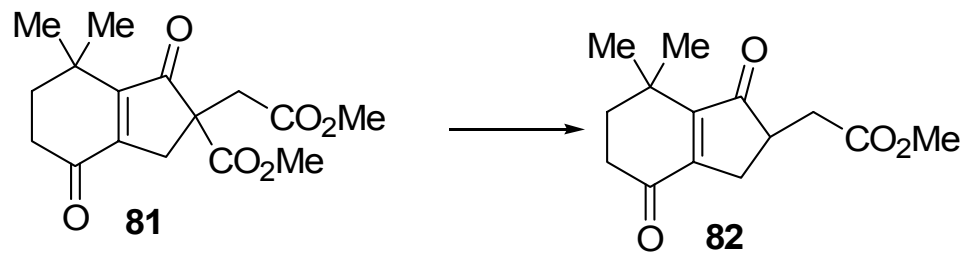

Treatment of $\mathbf{8 3}$ (THF $=$ 2-tetrahydrofuranyl) with DMSO-LiCl, sodium bicarbonate and water $\left(150^{\circ} \mathrm{C}, 3 \mathrm{~h}\right)$ led to racemic product $84(92 \%)$, which was converted into a intermediate for the synthesis of racemic perhydrohistrionicotoxin. ${ }^{43}$

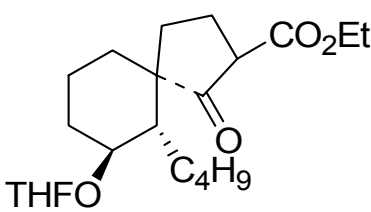

83

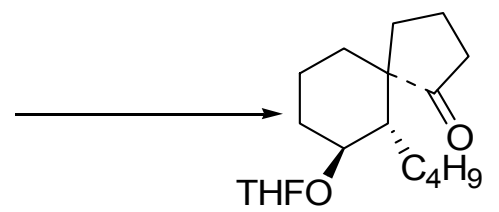

84

The demethoxycarbonylation of $\mathbf{8 5}$ (and the enol tautomer) with DMSO, LiCl and water $\left(165-170^{\circ} \mathrm{C}, 8 \mathrm{~h}\right)$ led to $86(67 \%)$ in which the tertiary ester was also hydrolyzed to the carboxylic acid. $^{44}$

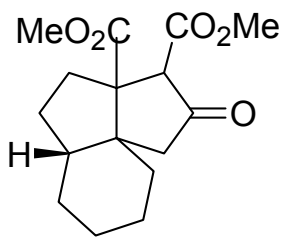

85

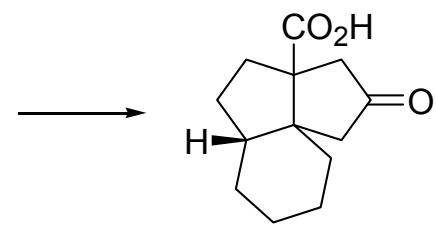

86

The demethoxycarbonylation of $\beta$-keto ester 87 with $\mathrm{DMSO}, \mathrm{NaCl}$ and water $\left(150^{\circ} \mathrm{C}, 8 \mathrm{~h}\right)$ led to 88 (88\%) which was used in a synthetic pathway to several natural tricyclic sequiterpenes. $^{45}$

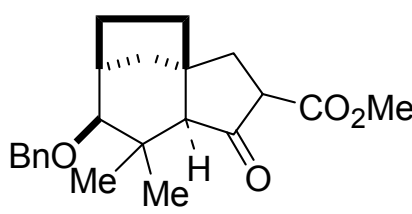

87

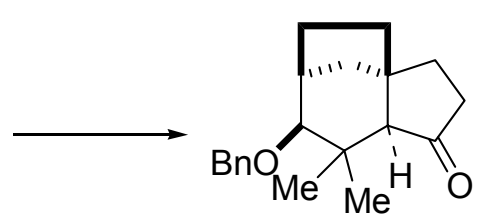

88

The $\beta$-keto ester 89 and $\mathrm{DMSO}, \mathrm{NaCl}$ and water $\left(110^{\circ} \mathrm{C}, 16 \mathrm{~h}\right)$ yielded 90 (72\%), which could be converted into other functionalized tricycloundecanes. ${ }^{46}$ 


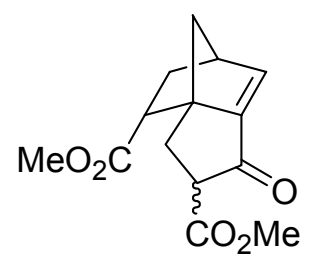

89

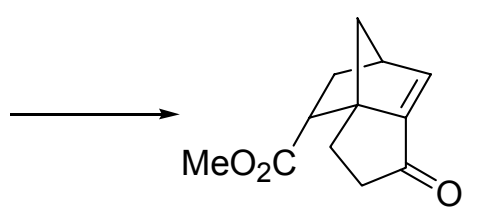

90

The deethoxycarbonylation of 91 with DMSO, $\mathrm{NaCl}\left(70^{\circ} \mathrm{C}, 3 \mathrm{~h}\right)$ led to (-)-92 (73\%, for 2 steps with prior $\mathrm{CrO}_{3}$ oxidation of alcohol to the ketone), a common intermediate utilized in the synthesis of the indole diterpenes $(+)$-paspalicine and (+)-paspalinine. ${ }^{47}$

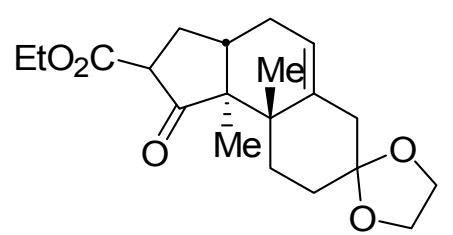

91

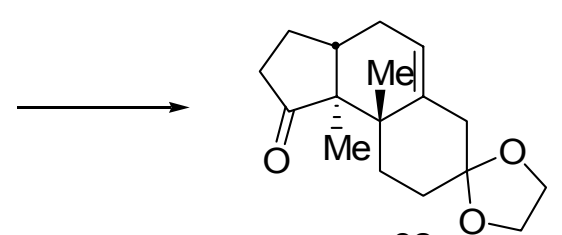

92

Treatment of racemic 93 with $\mathrm{DMSO}, \mathrm{LiCl}$ and water $\left(170^{\circ}, 1.25 \mathrm{~h}\right)$ led to racemic 94 $(92 \%)^{48}$

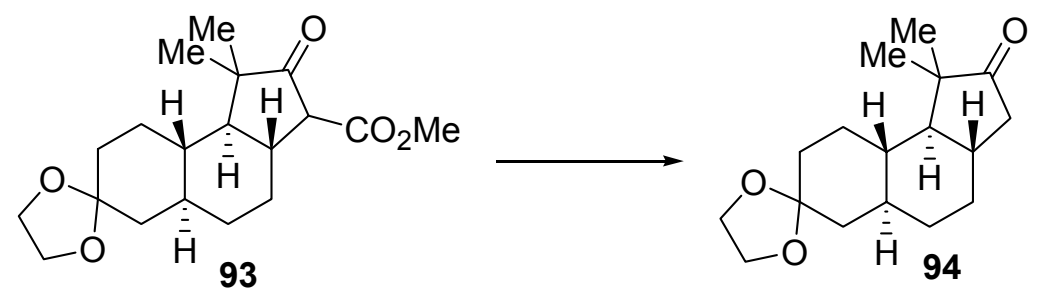

Treatment of 95 with DMSO, $\mathrm{NaCl}$ and water $\left(150^{\circ} \mathrm{C}\right)$ led to 96 , used in a synthesis of a racemic capnellene. ${ }^{49}$
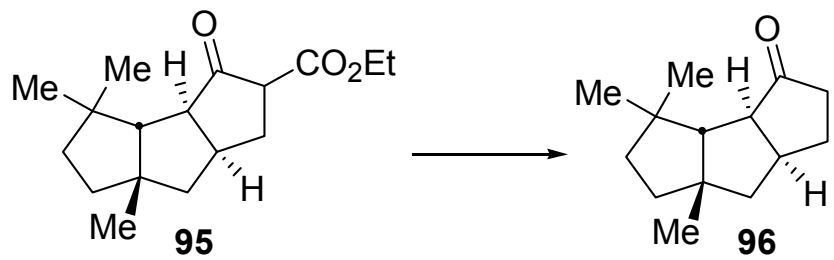

The deethoxycarbonylation of 97 with DMSO, $\mathrm{MgCl}_{2}$ hexahydrate $\left(140^{\circ} \mathrm{C}, 28 \mathrm{~h}\right)$ led to racemic 98 (74\%) with the $\alpha$-trisubstituted ester intact. Ester 98 was utilized in a synthesis of the sequiterpenes cedranediol and cedranoxide. ${ }^{50}$ 

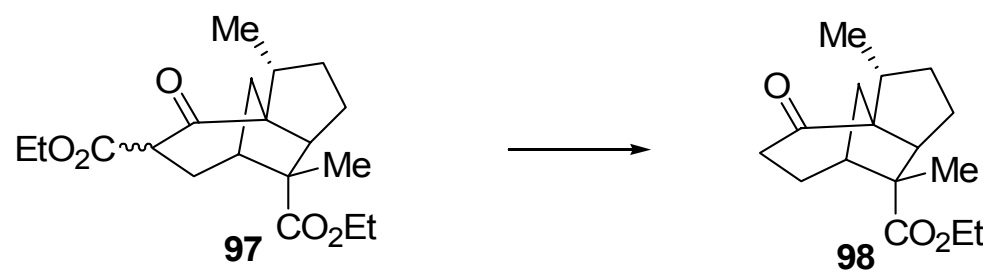

A 12:1 mixture of 99a and 99b on treatment with DMSO, $\mathrm{NaCl}$ and water (reflux, $24 \mathrm{~h}$ ) led to $\mathbf{1 0 0}(S)(83 \%$ ee $)(59 \%))^{51}$<smiles>[R]OC(=O)C1C(=O)CCCC1/C=C/[Na]</smiles>

99a<smiles>[R]OC(=O)C1C(=O)CCCC1/C=C/C</smiles>

99b<smiles>CC=CC1CCCC(=O)C1</smiles>

100

$\mathrm{R}=(-)$-phenylmenthyl

Treatment of 101 with DMSO and water $\left(130^{\circ} \mathrm{C}, 24 \mathrm{~h}\right)$ led to the demethoxycarbonylation product $102(2 S, 1 R)(99 \%)$ which in a number of steps could be converted into (-)-epibatidine, an alkaloid isolated from the skin of a Ecuadorian frog and exhibiting potent activity as a nonopiate analgesic. $^{52}$

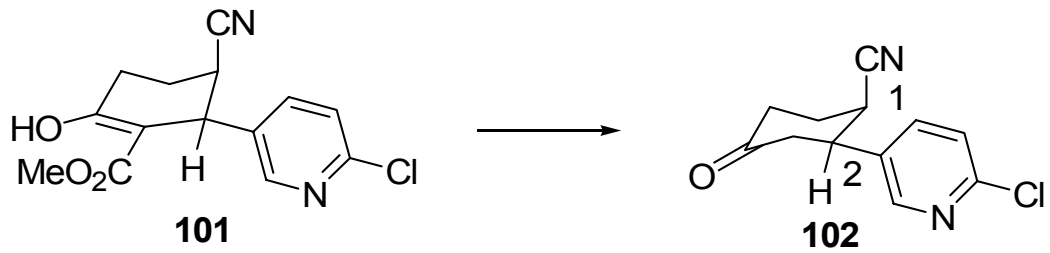

Treatment of optically active $\mathbf{1 0 3}$ with DMSO, $\mathrm{NaCl}$ and water $\left(180-185^{\circ} \mathrm{C}, 3.5 \mathrm{~h}\right)$ led to $(3 S)-104(79 \%) .^{53}$<smiles>CCOC(=O)[C@H]1CC[C@@H](OC(C)=O)C(C)(C)C1=O</smiles>

103<smiles></smiles>

104

The $\beta$-keto ester 105 underwent decarbomethoxylation when treated with DMSO, $\mathrm{NaCl}$ and water $\left(150^{\circ} \mathrm{C}, 4.5 \mathrm{~h}\right)$ to yield racemic $\beta$-vetivone 106 and racemic epi $\beta$-vetivone $(1.7: 1$ ratio) (77\%), which could be separated by column chromatography ${ }^{54}$. 

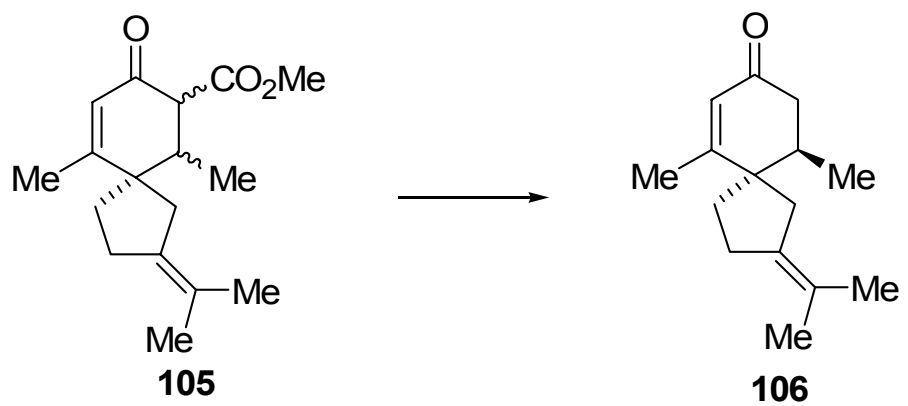

The spiro $\beta$-keto ester 107 on treatment with DMSO, $\mathrm{NaCl}$ and water $\left(130^{\circ} \mathrm{C}, 2 \mathrm{~h}\right)$ led to the $(1 R, 5 R)$ spiro[4,5]decan-7-one $(\mathbf{1 0 8}, 70 \%) .{ }^{55}$<smiles>C=C1CCC(C(C)C)C12CCCC(=O)C2=O</smiles><smiles>C=C1CCC(C(C)C)C12CCCCC2</smiles>

Treatment of 109 with DMSO and water $\left(115-120^{\circ} \mathrm{C}, 3 \mathrm{~h}\right)$ gave $110(73 \%) .^{56}$<smiles>COC(=O)C1CCCC2(CCCN2C)C1=O</smiles>

Treatment of 111 ( and the enolic tautomer) with DMSO, $\mathrm{NaCl}$ and water $\left(140^{\circ} \mathrm{C}, 4 \mathrm{~h}\right)$ led to homothujone 112 ( as a mixture of $\alpha$ - and $\beta$-diastereoisomers in a 10:1 ratio). ${ }^{57}$<smiles>CCOC(C)C1CCC(C(C)C)([C@]23CC2[C@@H](C)C3=O)C1</smiles>

111

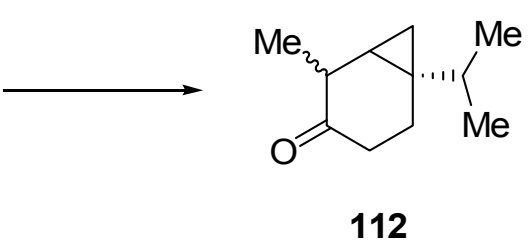

112

Treatment of enol 113 with DMSO, $\mathrm{LiCl}$ and water $\left(150^{\circ} \mathrm{C}, 4 \mathrm{~h}\right)$ led to 114 in a quantitative yield, which was utilized in a synthesis of a benzindene prostacyclin analogue. ${ }^{58}$<smiles>C=CCC1Cc2c(cccc2OC)CC1=O</smiles> 
Treatment of 115 with DMSO, $\mathrm{NaCl}$ and water (heat) led to $116(47 \%){ }^{59}$<smiles>CCOC(=O)C[C@H]1CC(=O)C2CCc3cc(OC)c(OC)cc3[C@H]2C1</smiles>

In a study dealing with thromboxane $\mathrm{A}_{2}$ analogues, it was reported that treatment of crude 117 (obtained as two regioisomers via a ring expansion of a prostaglandin intermediate with ethyl diazoacetate) with $\mathrm{DMSO}, \mathrm{NaCl}$ and water $\left(150^{\circ} \mathrm{C}, 2 \mathrm{~h}\right)$ led to optially active $\mathbf{1 1 8}(52 \%) .{ }^{60}$<smiles>CCOC(=O)C1CCC(/C=C/[C@H](CCCCC(=O)OC)OC(C)=O)[C@@H](C/C=C/CCCC(C)=O)C1=O</smiles>

117<smiles>CCCCCC[C@H](/C=C/[C@H]1CCCC(=O)[C@@H]1C/C=C/CCCC(C)=O)OC(C)=O</smiles>

118

In the total synthesis of tetracyclic Lycopodium alkaloids, the intermediate $\mathbf{1 2 0}$ was prepared by treatment of 119 with $\mathrm{NaCl}$ in DMF (no conditions or yield). ${ }^{61}$

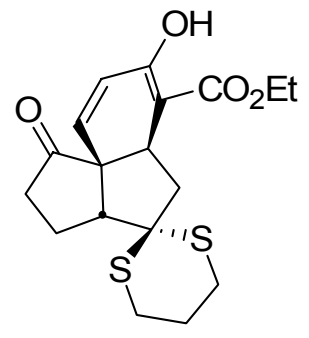

119

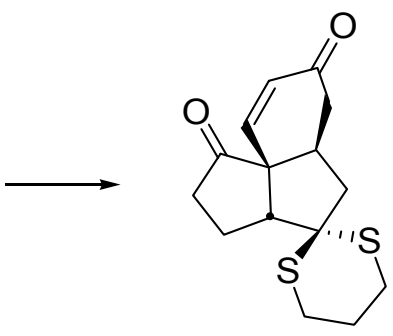

120

Treatment of $\beta$-keto ester 121 with DMSO, $\mathrm{NaCl}$ and water $\left(160^{\circ} \mathrm{C}, 6 \mathrm{~h}\right)$ led to $122(85 \%)$ which was used in a synthesis of racemic isoclovene, a tricyclic ketonic sesquiterpene. ${ }^{62}$<smiles>CCCOC(=O)CCC1(C)CCC(=O)CCC1(C)CCC(=O)OCC</smiles> 
Treatment of a number of bicyclic $\beta$-keto esters with $\mathrm{DMSO}, \mathrm{NaCl}$ and water led to the corresponding deethoxycarbonylated products. As an illustration, $\mathbf{1 2 3}$ on treatment with DMSO, $\mathrm{NaCl}$ and water (reflux, $2 \mathrm{~h}$ ) led to chiral $124(1 S, 6 S, 7 \mathrm{~S}, 9 R, 10 R)(86 \%)$, used in a route leading to an enantiospecific synthesis of clavukerin $\mathrm{A}$, a trinorguaiane sesquiterpene. ${ }^{63}$

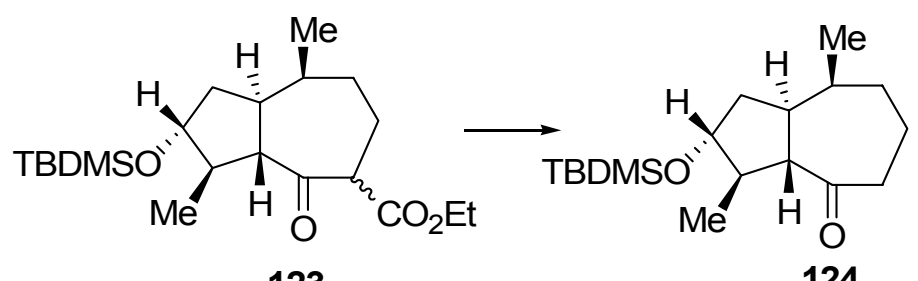

Treatment of 125 with DMSO, $\mathrm{NaCl}$ and water $\left(140^{\circ} \mathrm{C}, 0.5 \mathrm{~h}\right)$ led to $126(82 \%){ }^{64}$<smiles>CCOC(=O)C1=C(O)C(C)c2ccccc2C=C1</smiles>

Treatment of 127 with DMSO, $\mathrm{LiCl}$ and water $\left(175^{\circ} \mathrm{C}, 3 \mathrm{~h}\right)$ led to racemic $128(86 \%)$ which in a subsequent series of steps was converted into the furano sesquiterpene dihydropallescensin. ${ }^{65}$

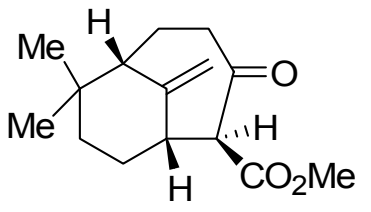

127

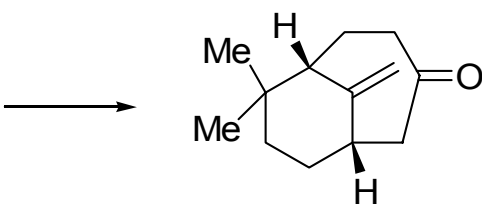

128

The deethoxycarbonylation of $\mathbf{1 2 9}$ with $\mathrm{DMSO}, \mathrm{NaCl}$ and water $\left(160^{\circ} \mathrm{C}, 3 \mathrm{~h}\right)$ led to $\mathbf{1 3 0}$ (quantitatively). This key intermediate, in a series of steps, was converted into the sesquiterpene, racemic isoclovene. ${ }^{66 a, b}$

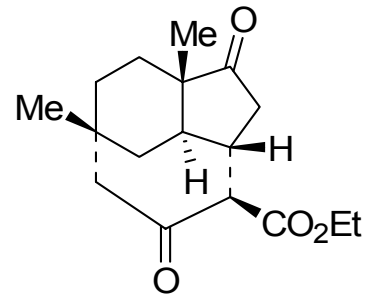

129

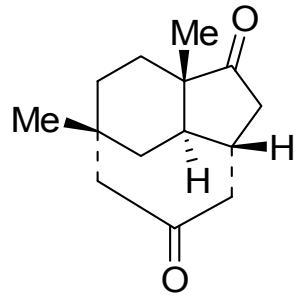

130 
The deethoxycarbonylation of 131 with $\mathrm{DMSO}, \mathrm{NaCl}$ and water $\left(150-160^{\circ} \mathrm{C}, 6 \mathrm{~h}\right)$ led to the hexacyclic dione $132(56 \%){ }^{67}$

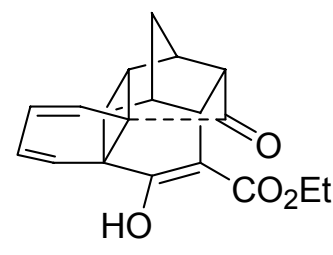

131

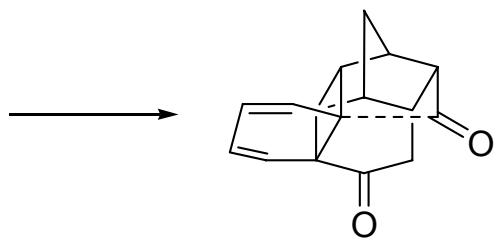

132

The deethoxycarbonylation of $\mathbf{1 3 3}$ with DMSO, $\mathrm{NaCl}$ and water $\left(150^{\circ} \mathrm{C}, 4 \mathrm{~h}\right)$ led to $\mathbf{1 3 4}$ $(91 \%){ }^{68}$

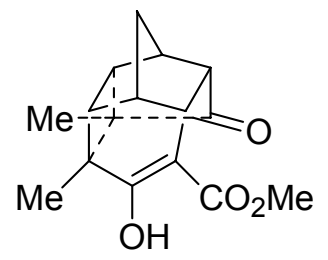

133

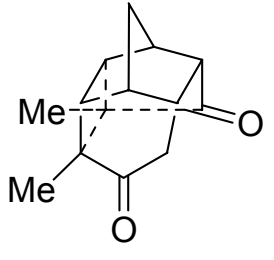

134

The deethoxycarbonylations of a mixture of chiral 135a and 135b with DMSO and water $\left(165^{\circ} \mathrm{C}, 4 \mathrm{~h}\right)$ led to $(R)-(-)$-muscone $(136,59 \%) .{ }^{69}$<smiles>CCOC(=O)C1C(=O)CCCC1C</smiles>

$135 a$<smiles>CCOC(C)(C)C1CCC(C)(C)CC1=O</smiles><smiles>[CH]C</smiles>

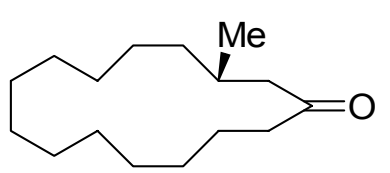

136

In synthetic routes to m-pyrrolophanes, the $\beta$-keto ester 137 on treatment with $\mathrm{DMSO}, \mathrm{NaCl}$ and water $\left(180-190^{\circ} \mathrm{C}, 1.5 \mathrm{~h}\right)$ led to ketopyrrole $138(91 \%){ }^{70}$

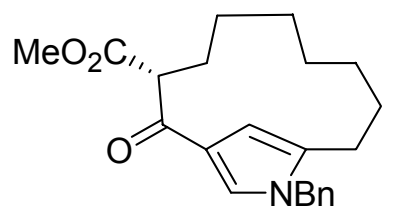

137

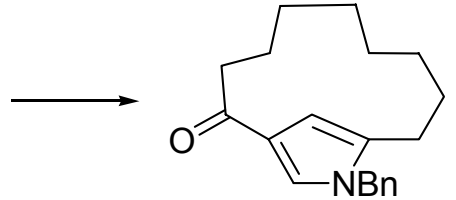

138

2.1.2.4. From heterocyclic $\beta$-keto esters. Treatment of macrocycle 139 with $\mathrm{DMSO}, \mathrm{LiCl}$ and water (reflux, $1 \mathrm{~h}$ ) led to 140 (78\%), which was used in a synthesis of glucosporone, an autoinhibitor of spore germination. $^{71}$ 


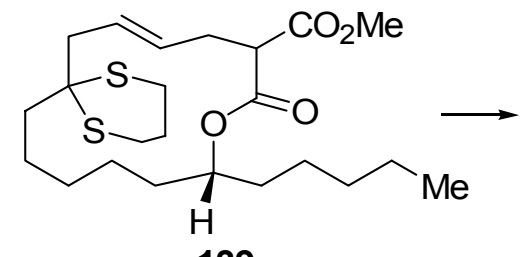

139

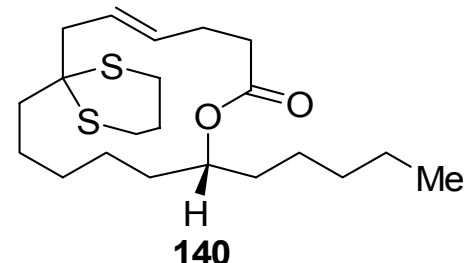

140

The lactone 141 on treatment in DMF with LiBr (reflux, 8 h) led to racemic $142(90 \%)$ used in a synthesis of the male sex pheromones of Carribean and Mexican fruit flies. ${ }^{72}$<smiles>C=C1CCC[C@@]2(C)OC(=O)[C@H](C(=O)OCC)C12</smiles><smiles>C=C1CCCC2(C)OC(=O)CC12</smiles>

Treatment of lactone 143 with DMSO, $\mathrm{NaCl}$ and water $\left(110^{\circ} \mathrm{C}\right)$ led to $144(83 \%)$, which in a subsequent series of steps could be converted into racemic Corey's lactone. ${ }^{73}$<smiles>COC[C@H]1C=CC2OC(=O)C(C(C)=O)C21</smiles><smiles>CO[C@H](C)[C@H]1C=C[C@H]2OC(=O)C[C@H]21</smiles>

Treatment of $(R)-\mathbf{1 4 5}$ with refluxing aqueous DMF for $12 \mathrm{~h}$ led to lactone $(R)-\mathbf{1 4 6}$ $\left(99 \%\right.$ ee) in good yield. ${ }^{74}$<smiles>COC(=O)[C@H]1C[C@](C)(c2ccccc2)OC1=O</smiles>

145

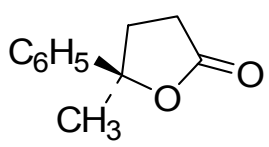

146

Treatment of 147 with DMSO, $\mathrm{LiCl}$ and water $\left(100^{\circ} \mathrm{C}, 24 \mathrm{~h}\right)$ led to racemic $148(85 \%)$ which was used in the synthesis of the partial ring skeleton of the ginkolides. ${ }^{75}$<smiles>[Z17]C[C@@H]1C(C(OC)OCc2ccccc2)C(=O)O[C@@H]1C1OCCO1</smiles><smiles>[13CH3]C[C@H]1CC(=O)O[C@@H]1C1OCCO1</smiles> 
Treatment of 149 with DMSO, $\mathrm{NaCl}$ and water $\left(180^{\circ} \mathrm{C}, 50 \mathrm{~min}\right)$ afforded 150 (95\%) which were used in a synthesis of guaianolides and related derivatives. ${ }^{76}$

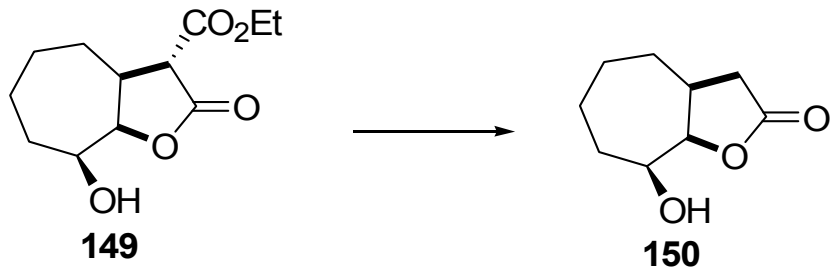

Lactam 151 on treatment with $\mathrm{DMF}, \mathrm{NaCl}$ and water (heat, $12 \mathrm{~h}$ ) led to $152(40 \%)$ and ring opened product $153(29 \%){ }^{77}$<smiles>CCOC(=O)C12C(=O)OC(C)(C)C1C(=O)N2c1ccc(OC)cc1</smiles><smiles>COc1ccc(N2C(=O)[C@@H]3[C@H](C)OC(=O)[C@H]32)cc1</smiles><smiles>COc1ccc(N2C(=O)[C@H](C(C)(C)O)[C@H](C(C)(C)O)[C@H]2C(C)(C)C)cc1</smiles>

The dealkoxycarbonylation of $\mathbf{1 5 4}$ (where $\mathrm{R}^{*}$ is a chiral appendage) with DMSO, $\mathrm{NaCl}$ and water at reflux led to $(S)-\mathbf{1 5 5}(84 \%){ }^{78}$

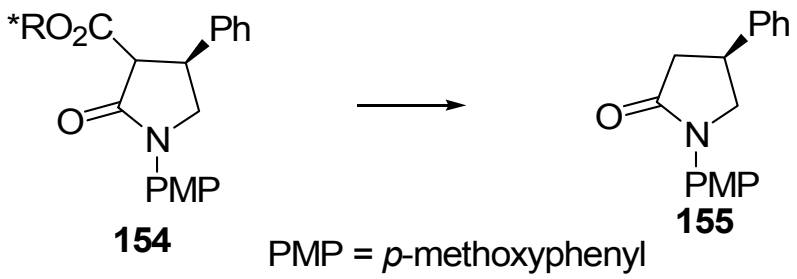

The deethoxycarbonylation of the $\beta$-keto ester 156 in $\mathrm{DMSO}, \mathrm{NaCl}$ and water $\left(130-135^{\circ} \mathrm{C}\right.$, $20 \mathrm{~h}$ ) led to a crude product which on chromatography gave enantiomer $157(36 \%){ }^{79}$
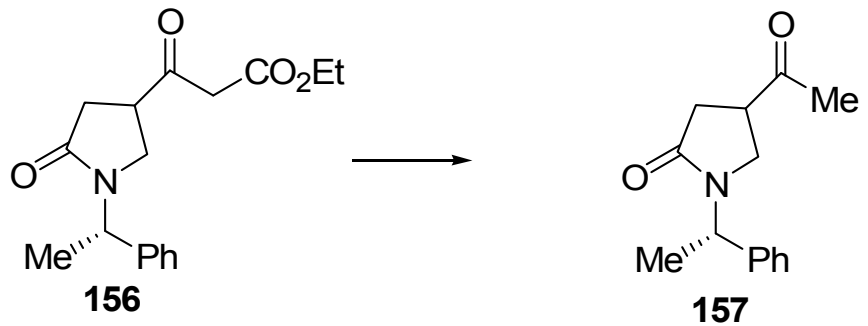

The optically active ester lactams $\mathbf{1 5 8 a}$ and $\mathbf{1 5 8 b}$ on treatment with $\mathrm{DMSO}, \mathrm{NaCl}$ and water $\left(150^{\circ} \mathrm{C}, 28 \mathrm{~h}\right)$ led to $\mathbf{1 5 9} \mathbf{a}$ and $\mathbf{1 5 9 b}$ in good yields. In $158 \mathrm{c}$, a similar procedure led to the desired product $159 \mathrm{c}$ along with some mono-desilylated product in a 1:4.3 ratio. ${ }^{80}$ 

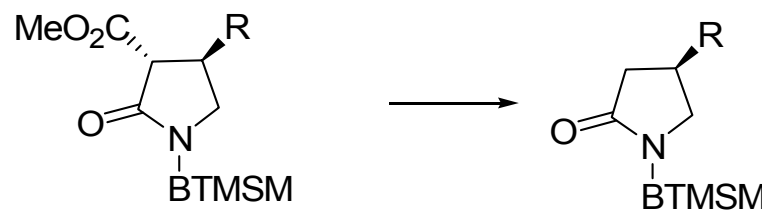

158

$\mathrm{BTMSM}=-\mathrm{CH}\left[\left(\mathrm{Si}\left(\mathrm{CH}_{3}\right)_{3}\right]_{2}\right.$

159

a, $\mathrm{R}=\mathrm{Ph} ; \mathrm{b}, \mathrm{R}=\mathrm{CH}_{2} \mathrm{Ph} ; \mathrm{c}, \mathrm{R}=4-\mathrm{MeOPh}$

Treatment of a number of 4-ethoxycarbonyl-N-substituted pyrrolidin-3-ones with DMSO, $\mathrm{NaCl}$ and water led to the corresponding decarbethoxylation products. For example treatment of 160a or 160b with $\mathrm{DMSO}, \mathrm{NaCl}$ and water $\left(130^{\circ} \mathrm{C}\right)$ led to $\mathbf{1 6 1 a}(81 \%)$ or $\mathbf{1 6 1 b}(83 \%)$, respectively. ${ }^{81}$<smiles>[R]C1([R])C(=O)[C@H](C(=O)OCC)CN1C(=O)OCC</smiles>

160

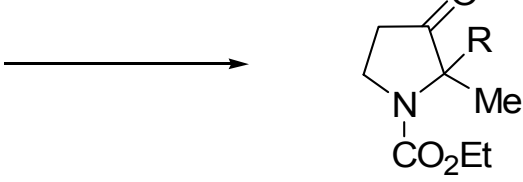

161

$\mathrm{a}, \mathrm{R}=\mathrm{H} ; \mathrm{b}, \mathrm{R}=n-\mathrm{C}_{5} \mathrm{H}_{11}$

A key 4-substituted 2-pyrrolidone intermediate 163 (97\%, which after crystallization led to an optically pure sample (71\%), was prepared by decarbomethoxylation of 162 (88\%ee) on treatment with $\mathrm{DMSO}, \mathrm{NaCl}$ and water $\left(160^{\circ} \mathrm{C}, 2 \mathrm{~h}\right)$. This intermediate was converted into a phoshodiesterase type IV inhibitor $(R)-(-)$-rolipram. ${ }^{82}$

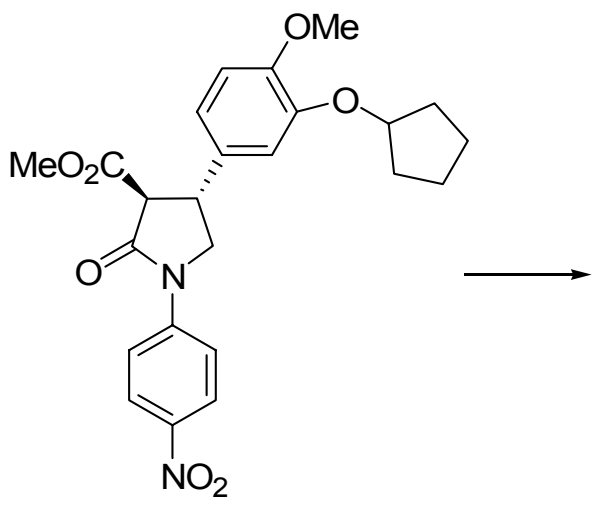

162

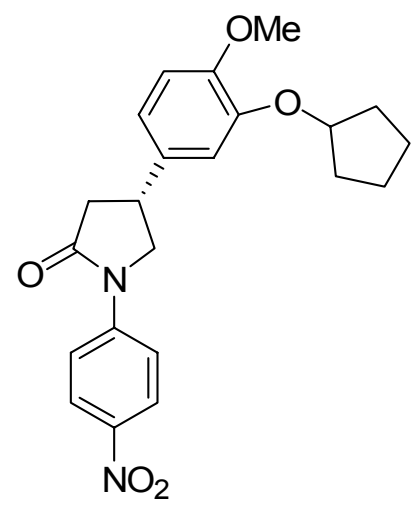

163

Treatment of the enol ester 164 with $\mathrm{DMSO}, \mathrm{NaCl}$ and water $\left(155-160^{\circ} \mathrm{C}, 3 \mathrm{~h}\right)$ led to the 3 oxo-2-piperidine-propionic acid 165 (78\%). The intramolecular acylation of this analogue into the corresponding enol lactone was accomplished. ${ }^{83}$ 


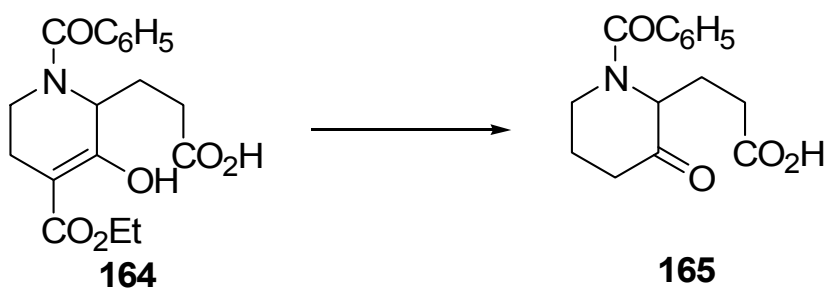

Enantiomer 166 with DMSO, $\mathrm{NaCl}$ and water $\left(160-170^{\circ} \mathrm{C}, 1 \mathrm{~h}\right)$ led to enantiomer $167(63 \%)$, an intermediate used in the study of the synthesis of $(+)$-sesbanimide. ${ }^{84}$ In this case, perhaps the addition of salt might not be necessary.<smiles>COC(=O)C1C(=O)NC(=O)C[C@@H]1[C@@H]1OCO[C@H](Br)[C@@H]1OC</smiles>

166<smiles>CO[C@@H]1[C@H](C2CC(=O)NC(=O)C2)OCO[C@H]1OCc1ccccc1</smiles>

167

The deallyloxycarbonylation of substrate 168 with DMF, $\mathrm{MgCl}_{2}$ hexahydrate and water (reflux, $20 \mathrm{~h}$ ) yielded $169(91 \%){ }^{85}$<smiles>C=CCOC(=O)C1C(=O)C=CSC1CCCC</smiles>

168<smiles>CCCCC1CC(=O)C=CS1</smiles>

169

The decarbomethoxylation of $\mathbf{1 7 0}$ in $\mathrm{DMSO}, \mathrm{NaCl}$ and water $\left(155^{\circ} \mathrm{C}, 10 \mathrm{~h}\right)$ led to $\mathbf{1 7 1}(99 \%)$ which was converted into racemic pyrrolizidine alkaloid isoretronecanol. ${ }^{86}$<smiles>COC(=O)[C@H]1C(=O)N(Cc2ccccc2)C2CCC=C[C@@H]21</smiles><smiles>O=C1C[C@@H]2C=CCC[C@H]2N1Cc1ccccc1</smiles>

The decarbomethoxylation of a mixture of the enol esters 172 and 173 in DMSO, $\mathrm{NaCl}$ and water $\left(130^{\circ} \mathrm{C}, 4 \mathrm{~min}\right)$ led to the indolizinone $174(92 \%)$. Intermediate 174 was subsequently transformed in a series of steps into natural $(+)$-lentiginosine. ${ }^{87}$ 
<smiles>COC(=O)C1=C(O)C[C@@H]2[C@@H](OCc3ccccc3)CN2C1</smiles>

172<smiles>COC(=O)C1=C(O)CCN2C[C@H](O[Sb](C)(=O)=O)[C@H](OCc3ccccc3)[C@H]12</smiles>

173<smiles>O=C1CCN2C[C@H](O[SbH3])[C@@H](O[SbH3])[C@H]2C1</smiles>

174

Treatment of 175 with DMSO, $\mathrm{NaCl}$ and water $\left(155-160^{\circ} \mathrm{C}, 3 \mathrm{~h}\right)$ gave $176(74 \%) .{ }^{88}$<smiles>COC(=O)C1=C(O)C2(C)CCC(C1)N2C(=O)c1ccccc1</smiles>

175<smiles>CC12CCC(CC1=O)N(C(=O)c1ccccc1)C2</smiles>

176

Treatment of $(R)-\mathbf{1 7 7}$ with DMSO, $\mathrm{NaCl}$ and water $\left(140^{\circ} \mathrm{C}, 3 \mathrm{~h}\right)$ led to $(R)-\mathbf{1 7 8}(60 \%)$. However, the ee of $(\mathrm{R}) \mathbf{- 1 7 8}$ was only $0.5 \%$ which appeared to indicate that racemization had occurred in the demethoxycarbonylation step. ${ }^{89}$

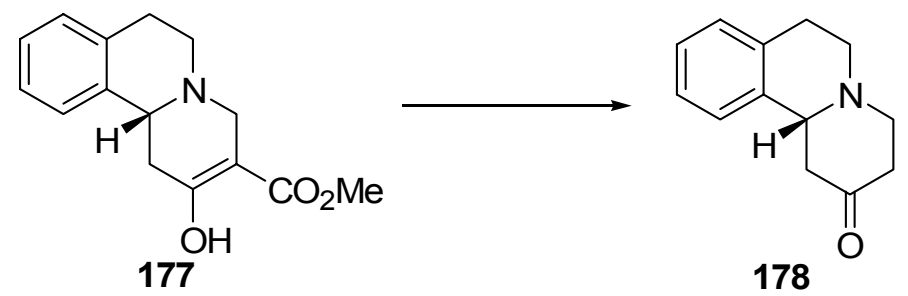

The decarbomethoxylation of (-)-179 (and the enol form) with $\mathrm{DMF}, \mathrm{NaCl}$ and water $\left(130^{\circ} \mathrm{C}\right.$, $6 \mathrm{~h})$ led to $(-)-\mathbf{1 8 0}(73 \%,>95 \% \mathrm{ee})$. A similar procedure on the enantiomer led to $(+)-\mathbf{1 8 0}$ These intermediates could then be converted into several indole alkaloids such as (-)-ajmaline. ${ }^{90}$

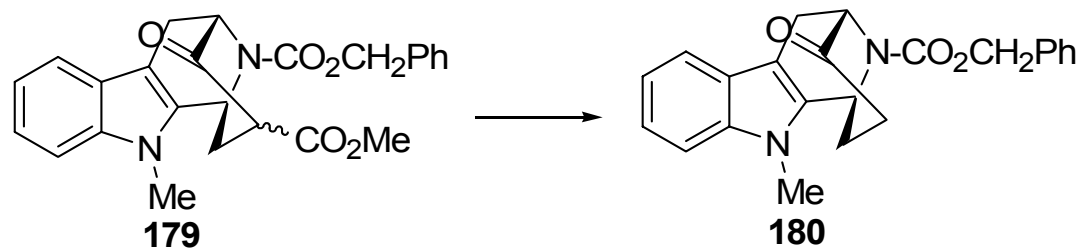

The demethoxycarbonylation of derivative 181 proved to be quite difficult. The best result was obtained by treatment of $\mathbf{1 8 1}$ with dry DMSO and LiI dihydrate $\left(132^{\circ} \mathrm{C}, 36 \mathrm{~h}\right)$ to afford 182 $(56 \%)$. The use of $\mathrm{DMSO}, \mathrm{NaCl}$ and water at $180^{\circ} \mathrm{C}$ did not lead to demethoxycarbonylation. ${ }^{91}$ 


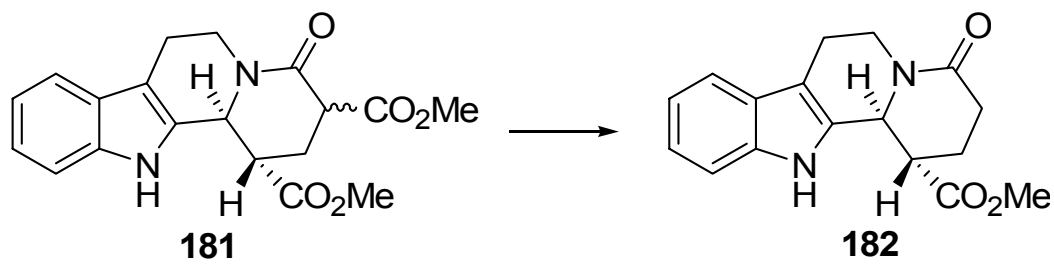

Treatment of ester 183 with DMSO, $\mathrm{LiCl}$ and water $\left(160^{\circ} \mathrm{C}, 3.5 \mathrm{~h}\right)$ led to $\mathbf{1 8 4}(99 \%$ ee). This intermediate was converted into $(+)$-geissoschizine. ${ }^{92}$<smiles>CCOC(=O)C1CCC2c3[nH]c4ccccc4c3CCN2C1=O</smiles>

183<smiles>COC(=O)c1cccc2[nH]c3c(c12)CCN1C(=O)CCC[C@H]31</smiles>

184

The decarbomethoxylation of of $\mathbf{1 8 5}$ with $\mathrm{DMSO}, \mathrm{LiCl}$ and water $\left(150^{\circ} \mathrm{C}, 25 \mathrm{~min}\right)$ led to $\mathbf{1 8 6}$ (98\% ee), a known degradation product of vindoline. ${ }^{93}$

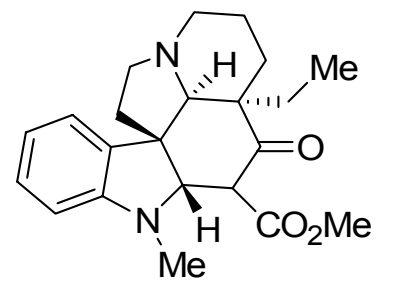

185

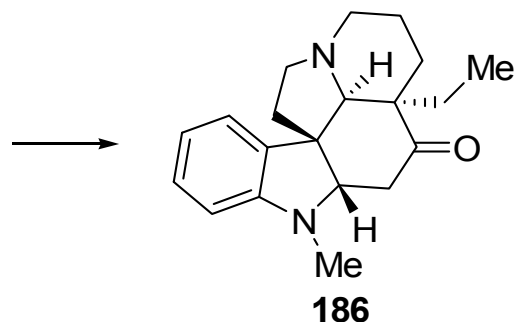

186

Keto ester 187 on treatment with DMSO, $\mathrm{LiCl}$ and water (reflux, $2.5 \mathrm{~h}$ ) led to $\mathbf{1 8 8}(78 \%)$. A subsequent series of steps led to the racemic sesquiterpene davanone. ${ }^{94}$
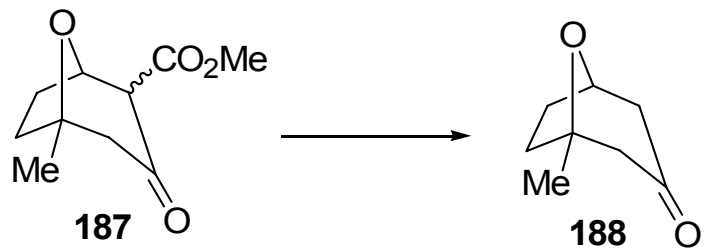

In approaches to the cladiellin skeleton, the intermediate 189 on treatment with $\mathrm{LiCl}$, DMSO $\left(130^{\circ} \mathrm{C}, 3 \mathrm{~h}\right)$ and water led to enantiomer $190(86 \%) .{ }^{95}$ 


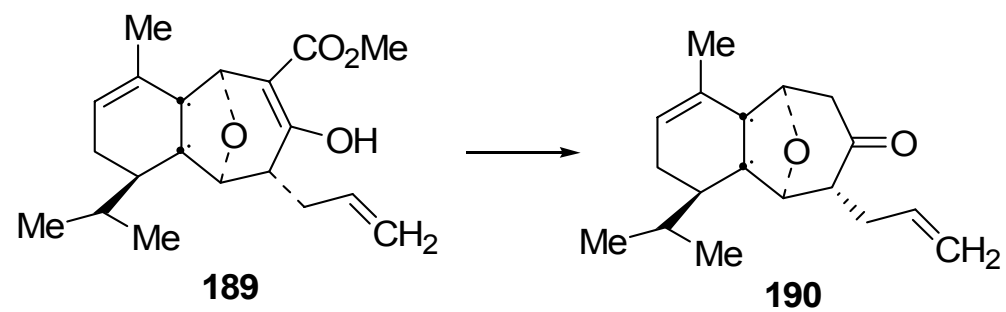

The preparation of enantiomer 192 (41\%) was perfomed by heating 191 in dry DMF and LiI dihydrate $\left(130^{\circ} \mathrm{C}, 2.5 \mathrm{~h}\right){ }^{96}$
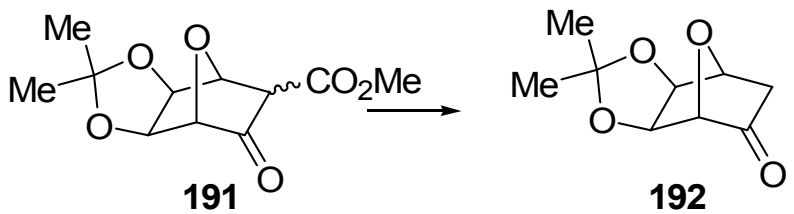

The demethoxycarbonylation of 193 (and the tautomeric enolic ester) was easily accomplished in DMSO and water $\left(150^{\circ} \mathrm{C}, 1 \mathrm{~h}\right)$ to yield the thienoazepine dione $194(82 \%) \cdot{ }^{97} \mathrm{~A}$ related pyrimidine analogue underwent deethoxycarbonylation in DMSO and anhydrous $\mathrm{NaCl}{ }^{98}$<smiles>COC(=O)C1CC(=O)Nc2ccsc2C1=O</smiles>

Additonal examples are tabulated in Table 1. 
Table 1. Dealkoxycarbonylations of monosubstituted $\beta$-keto esters

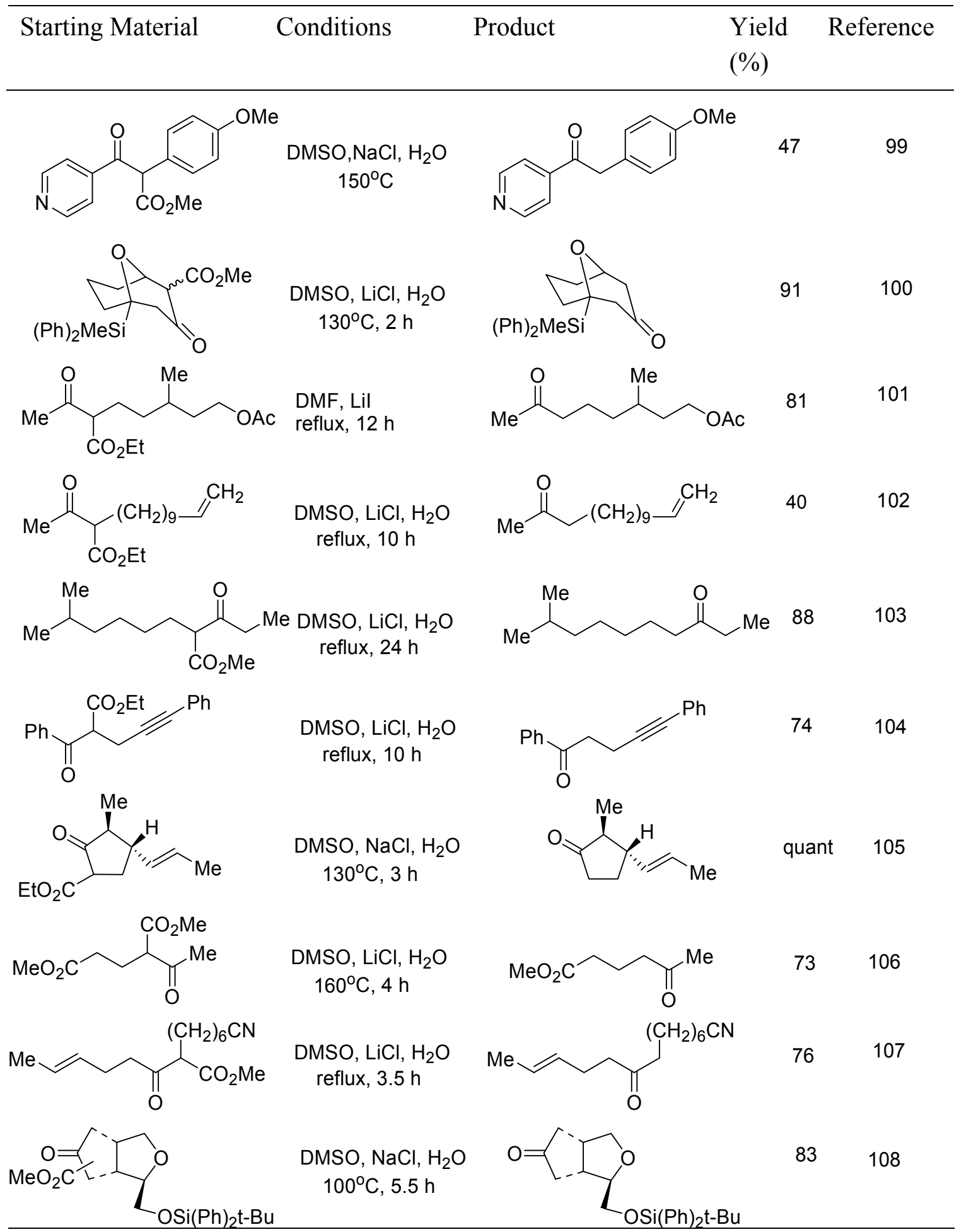


2.1.2.5. From an $\boldsymbol{\alpha}, \boldsymbol{\alpha}$-diethoxycarbonyl ketone. Treatment of 195 with $\mathrm{DMSO}, \mathrm{NaCl}$ and water $\left(160-170^{\circ} \mathrm{C}, 6 \mathrm{~h}\right)$ afforded $196(90 \%)$ the bis-deethoxycarbonylation product 196 $(90 \%){ }^{109}$

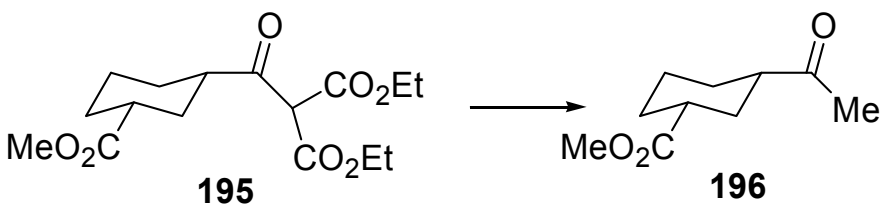

\subsection{Disubstituted $\beta$-keto esters}

\subsubsection{Water alone}

The de-t-butoxycarbonylation of the bis-(thiomethyl) substrate 197 with DMSO and water $\left(160^{\circ} \mathrm{C}, 4 \mathrm{~h}\right)$ led to 1,1-bis-(methylthio)-2-propanone $198(85 \%) .{ }^{110}$

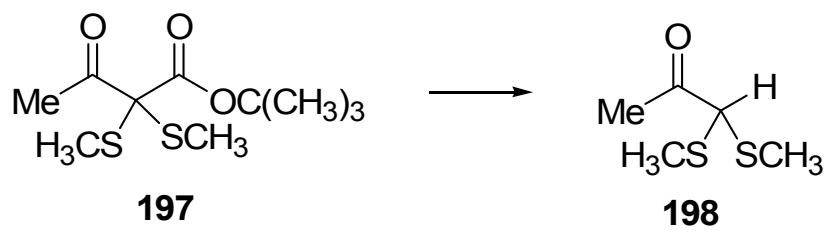

\subsubsection{Water-salts}

2.2.2.1. Open chain substitutents. The racemic $\beta$-keto ester 199 on heating in DMSO with $\mathrm{LiCl}$ and water $\left(170^{\circ} \mathrm{C}, 1.5 \mathrm{~h}\right)$ led to a key intermediate $200(89 \%)$, which was converted in 2 steps to racemic stigmalone. ${ }^{111}$<smiles>C=C(C)CCC(C)(CCC)C(=O)CC(C)C</smiles>

199<smiles>C=C(C)CCC(C)C(=O)CC(C)C</smiles>

200

A number of 3-acyloxymethyl ketones were synthesized by the chemoselective dealkoxycarbonylation of the tert-butoxycarbonyl group using $\mathrm{DMSO}, \mathrm{LiCl}$ and water $\left(160^{\circ} \mathrm{C}, 5\right.$ h). A typical illustrative example is the conversion of 201 to $202(64 \%) .{ }^{112}$ In this case the presence of the salt might not be necessary.<smiles>CCOC(=O)C(CC=C(C)C)(OC(C)=O)C(=O)OCc1ccccc1</smiles>

201<smiles>CC(=O)OC(CC=C(C)C)C(C)=O</smiles>

202 
The preparation of a number of 1-alkyl-1,3-dimethoxyacetones has been accomplished by treatment of the appropriate $\beta$-keto ester with $\mathrm{DMSO}, \mathrm{LiCl}$ and water $\left(120-140^{\circ} \mathrm{C}, 10 \mathrm{~h}\right)$. For example, under these reaction conditions the demethoxycarbonylation of $\mathbf{2 0 3}$ led to 204 $(72 \%)^{113}$<smiles>COCC(=O)C(OC)C(C)OC</smiles>

\subsubsection{From carbocyclic $\beta$-keto esters}

2.2.2.3. Water-salts. Treatment of 205 with $\mathrm{DMSO}, \mathrm{NaCN}$ and water $\left(140^{\circ} \mathrm{C}, 1 \mathrm{~h}\right)$ led to 206 $(53 \%){ }^{114}$

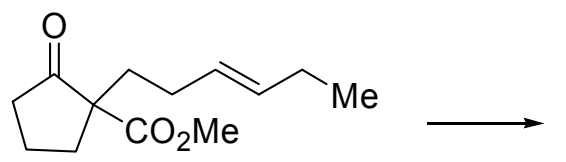

205

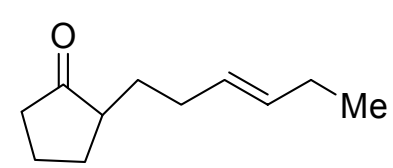

206

Upon treatment of 207 with DMSO and $\mathrm{NaCN}\left(135-140^{\circ} \mathrm{C}, 2 \mathrm{~h}\right)$ the de-ethoxycarbonylation and displacement of the bromide occurred to afforded nitrile $208(75 \%) .{ }^{115}$

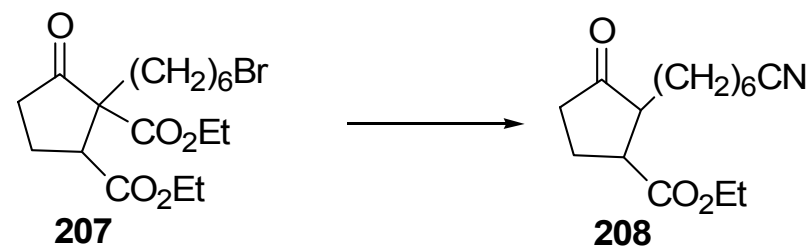

Treatment of enantiomer 209 with DMF and LiI (reflux, 2 h) led to enantiomer 210 (76\%), which was used in a synthesis of a triquinane portion of retigeranic acid. ${ }^{116}$

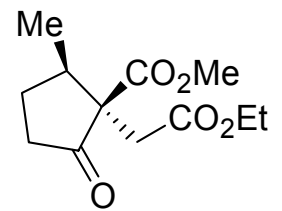

209
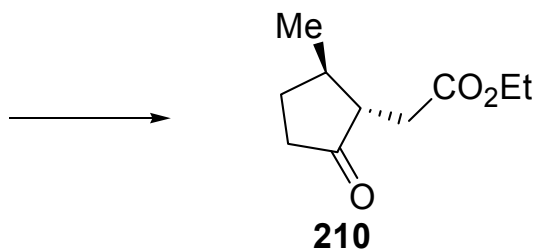

Treatment of 211 with DMSO, $\mathrm{NaCl}$, water $\left(155-160^{\circ} \mathrm{C}, 5 \mathrm{~h}\right)$ led to 212 (53\%), along with some ring-opened product. This intermediate was to be used in a synthetic approach to 11deoxyprostaglandins. ${ }^{117}$ 

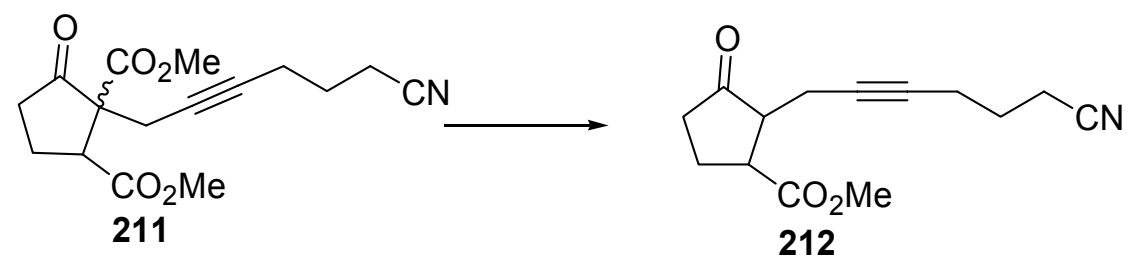

In studies dealing with the synthesis of protaglandins, the treatment of 213 with HMPA and $\mathrm{NaCN}\left(75-80^{\circ} \mathrm{C}, 1.5 \mathrm{~h}\right)$ led to racemic $214 .{ }^{118}$

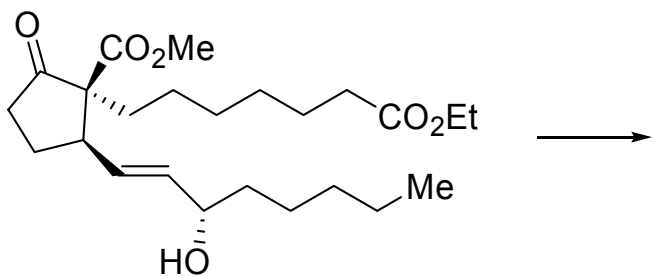

213

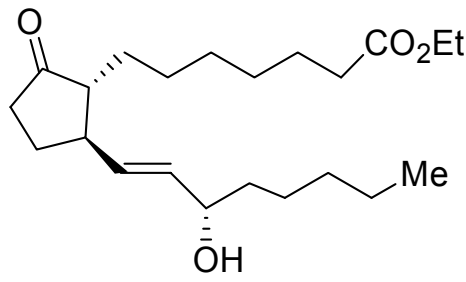

214

The $\beta$-keto ester 215 on treatment with DMF and LiI (reflux, 8 h) led to $216(85 \%)$, a prostaglandin synthon. ${ }^{19}$<smiles>C=C(C)CCC/C=C(\C)CC1CCCC1C(=O)CCCC(=C)O</smiles>

The synthesis of racemic jasmonate 218 (78\%) was accomplished by heating $\beta$-keto ester 217 in DMSO, $\mathrm{NaCl}$ and water $\left(180^{\circ} \mathrm{C}, 4 \mathrm{~h}\right.$, sealed tube) ${ }^{120}$

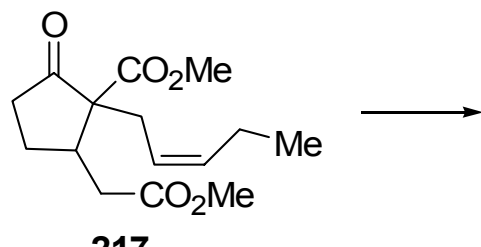

217<smiles>CC/C=C\CC1C(=O)CCC1CC(C)=O</smiles>

218

Racemic 219 on treatment with $\mathrm{DMSO}, \mathrm{NaCl}$ and water $\left(170^{\circ} \mathrm{C}, 18 \mathrm{~h}\right)$ led to methyl dihydrojasmonate $220(83 \%)$. Under these conditions the demethoxycarbonylation of only the $\beta$ keto ester moiety occurred. ${ }^{121}$

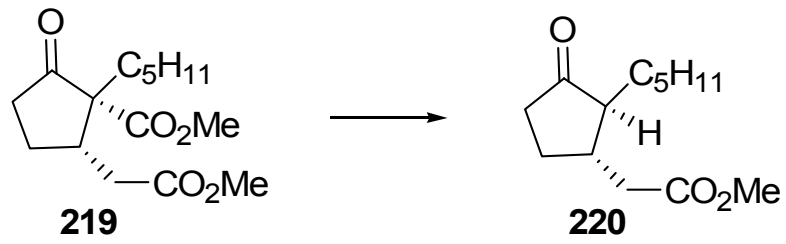


Treatment of 221 with $\mathrm{HMPA}$ and $\mathrm{NaCN}\left(75^{\circ} \mathrm{C}, 5 \mathrm{~h}\right)$ led to chiral $(2 R, 3 R, 1 R)-\mathbf{2 2 2}(72 \%) .{ }^{122}$

Treatment of (+)-223 with DMSO, $\mathrm{NaCN}$ and water $\left(140^{\circ} \mathrm{C}, 36 \mathrm{~h}\right)$ led to ketone $(S)-\mathbf{2 2 4}$ $(89 \%)$ with a trans:cis ratio of $9: 1$. The mixture of ketones was converted into the sesquiterpenic alcohol (+)-conocephalenol in several subsequent steps. ${ }^{123}$<smiles>C=C(C)CC1(C(=O)OC)C(=O)CCC1C</smiles>

223

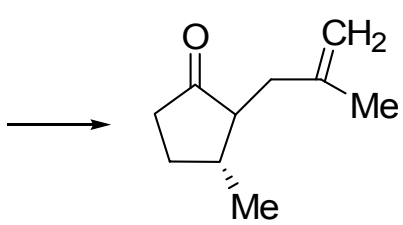

224

The decarbomethoxylation of 225 in DMSO and $\mathrm{NaCN}\left(160^{\circ} \mathrm{C}, 2 \mathrm{~h}\right)$ yielded $226(92 \%)$ used in a synthesis of chiral phenylalanine analogues isolated from Praxelis clematidea. ${ }^{124}$<smiles>CC(=O)OCC#CCC1(C(C)=O)CCCC1=O</smiles>

225

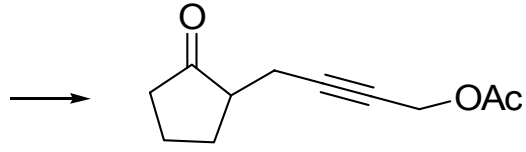

226

On treatment of (-)-227 (a vinylogous $\beta$-keto ester) with DMF and LiI trihydrate (reflux, $1 \mathrm{~h}$ ) the demethoxylated products (+)-228a and (-)-228b (90\%, 5:4 ratio) were isolated and could be separated by chromatography. Compound 228a was subsequently converted into the chiral sequiterpene alcohol (-)-silphiperfol-5-en-3-ol. ${ }^{125}$<smiles>CCCCCC1(C(=O)OC)CC(=O)C(C)=C1C</smiles>

227

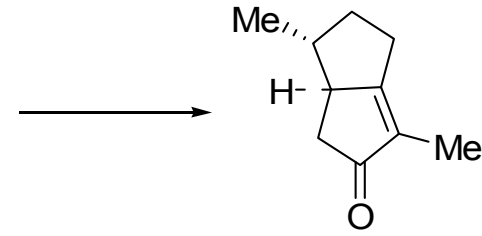

228a

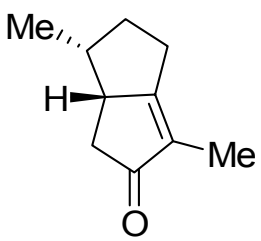

228b

In the preparation of 16 -(bromoalkyl)-estradiols, the intermediate $230(71 \%$, as a $16 \alpha, 16 \beta$ mixture 15:85) was obtained by treatment of 229 with $\mathrm{DMF}, \mathrm{LiCl}$ and water (reflux). Other side chains at C-16 were also prepared by this route. ${ }^{126}$<smiles>C=CCCCC1(C)CC2C3CCc4cc(OC)ccc4C3CCC2(C)C1=O</smiles>

229<smiles>C=CCCCCCCCCCCCCCCCCCC</smiles> 
Treatment of $231 \mathrm{a}$ or $\mathbf{2 3 1 b}$ with DMSO, $\mathrm{LiCl}$ and water $\left(180^{\circ} \mathrm{C}, 1.5 \mathrm{~h}\right)$ led to $232 \mathrm{a}(64 \%)$ or $232(78 \%)$, respectively. ${ }^{127}$<smiles>[R]C1(C(C)=O)CCCCC1=O</smiles>

231

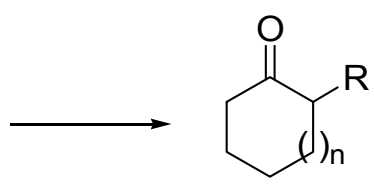

232

a, $\mathrm{R}=\mathrm{C}_{5} \mathrm{H}_{11}, \mathrm{n}=1 ; \mathrm{R}=\mathrm{C}_{5} \mathrm{H}_{11}, \mathrm{n}=2$

The decarbomethoxylation of 233 with $\mathrm{DMSO}, \mathrm{NaCl}$ and water $\left(160^{\circ} \mathrm{C}\right)$ led to a mixture of cis- and trans isomers 234 which could be separated by chromatography. These isomers were used in the synthesis of the sesquiterpene racemic vetiselinene. ${ }^{128}$<smiles>COCC1(OC)CC=CCC12C(=O)CCC[C@@H]2OC</smiles><smiles>CO[C@H]1C=CC[C@]2(C)C(=O)CCC[C@H]12</smiles>

The Krapcho dealkoxycarbonylations of substituted cyclic $\beta$-keto esters using $\mathrm{LiBr}, \mathrm{Bu}_{4} \mathrm{NBr}$ and water under microwave irradiation have been reported. For example, under these conditions the conversion of $\mathbf{2 3 5}$ to $\mathbf{2 3 6}$ (87\%) was accomplished in $20 \mathrm{~min}$ at $186^{\circ} \mathrm{C}$. ${ }^{129, \mathrm{~b}, \mathrm{c}}$<smiles>CCOC(=O)CC1(C)CCCCC1=O</smiles>

235

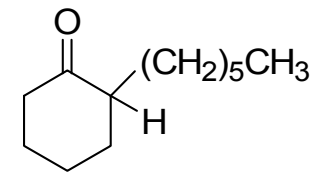

236

The $\beta$-keto ester 237 on treatment with DMPU (dimethylpyrimidinone) and $\mathrm{LiCl}\left(130^{\circ} \mathrm{C}, 48\right.$ h) gave cyclohexenone 238 (45\%). ${ }^{130}$

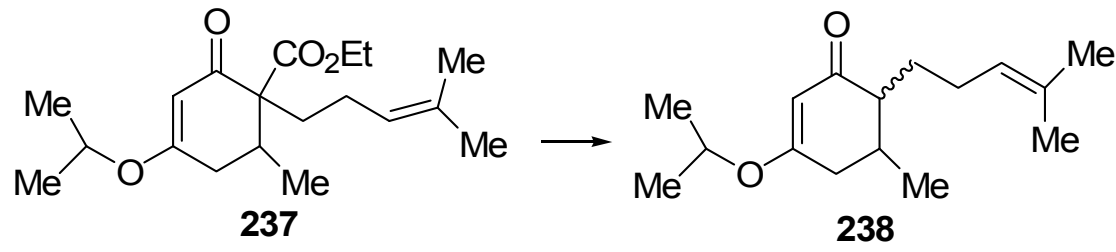

Treatment of 239 with HMPA and $\mathrm{LiCl}\left(130^{\circ} \mathrm{C}\right)$ led to the demethoxycarbonylated product $240(72 \%)$ which was converted into $(+)$-dysideapalaunic acid, a sesquiterpene aldose reductase inhibitor. $^{131}$ 

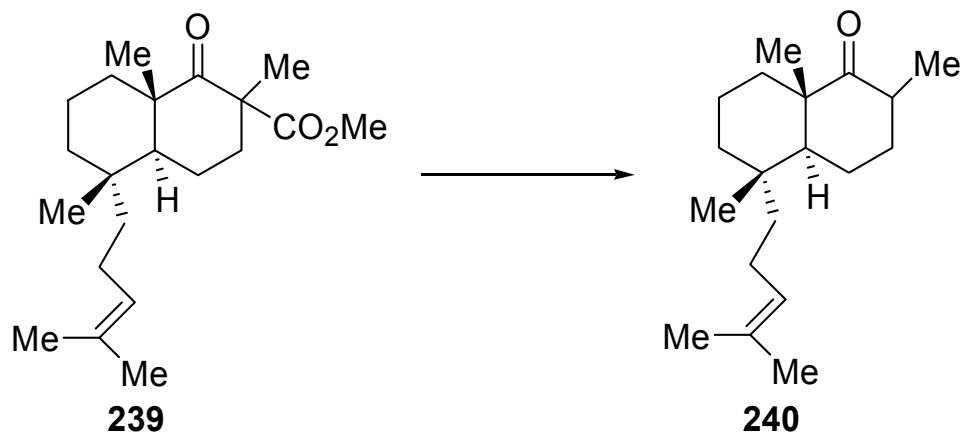

Treatment of 241 with $\mathrm{LiCl}$ in HMPA $\left(130^{\circ} \mathrm{C}\right)$ afforded $242(92 \%)$ which was used in at synthesis of $(+)$-perrottetianal $\mathrm{A}$, sacculatane diterpene. ${ }^{132}$
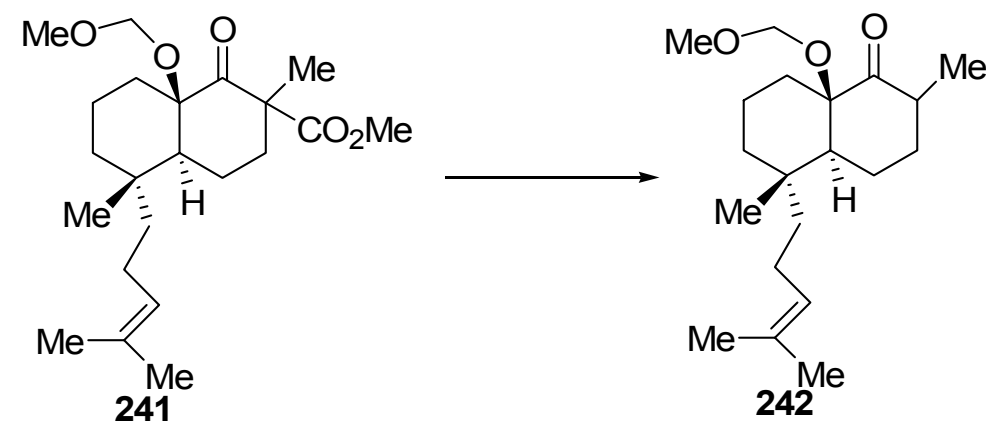

The crystalline and oily stereoisomers 243 were treated with HMPA and $\mathrm{LiCl}\left(120-140^{\circ} \mathrm{C}, 8\right.$ h) to afford the dione 244 (84\%), which was subsequently converted into (+)-pisiferol, an abietane-type diterpene alcohol. ${ }^{133}$<smiles>COC[C@]12CCCC(C)(C)[C@@H]1CCC(CCC(C)=O)(CC(C)=O)C2=O</smiles>

243

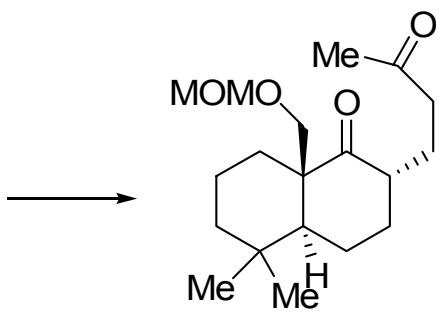

244

The demethoxycarbonylation of $\mathbf{2 4 5}$ with $\mathrm{HMPA}$ and $\mathrm{LiCl}$ (anhydrous conditions, $100^{\circ} \mathrm{C}, 20$ h) led to a epimeric mixture of tricyclic ketones 246 (82\%) which were subsequently converted into racemic sterpurene, a sesquiterpene hydrocarbon metabolite of Chondrostereum purpureum. $^{134}$ 

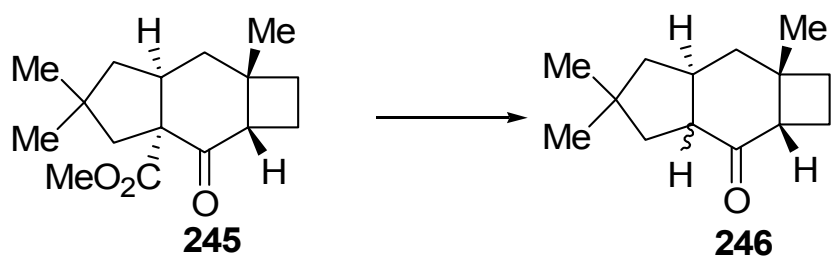

Treatment of $247 \mathbf{a}(1-\beta-\mathrm{H})$ or $\mathbf{2 4 7} \mathbf{b}(1-\alpha-\mathrm{H})$ with $\mathrm{DMSO}, \mathrm{NaCl}$ and water at reflux led to 248a or $248 \mathbf{b}(90 \%)$, which were used in the synthesis of a defense substance of a termite soldier. $^{135}$
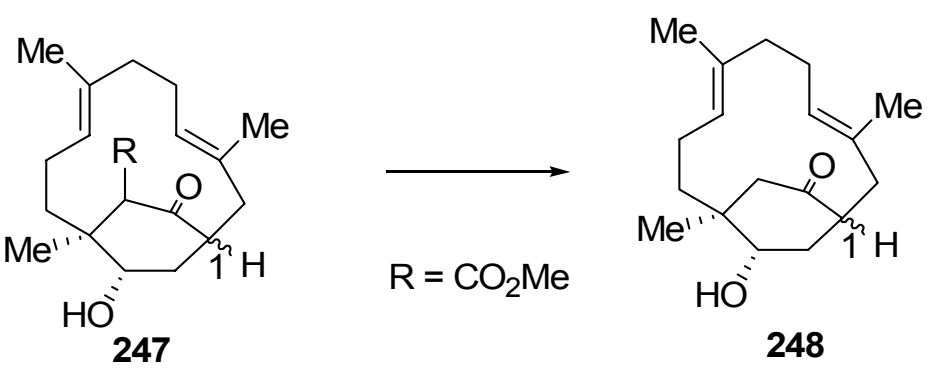

Treatment of 249 with DMSO, $\mathrm{NaCl}$ and water $\left(150^{\circ} \mathrm{C}, 6 \mathrm{~h}\right)$ led to the decarbomethoxylation to afford racemic 250 (36\%), an intermediate in approaches to a group of sesquiterpenes called tremulanes. ${ }^{136}$

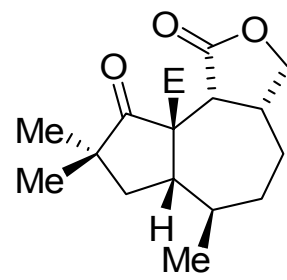

249

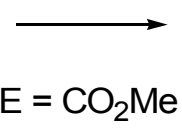

$\mathrm{E}=\mathrm{CO}_{2} \mathrm{Me}$

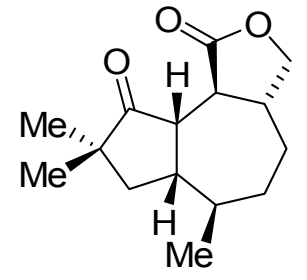

250

The decarbomethoxylation of $\mathbf{2 5 1}$ in aqueous DMSO (no conditions) led to ketone $\mathbf{2 5 2}$ $(99 \%) .{ }^{137}$

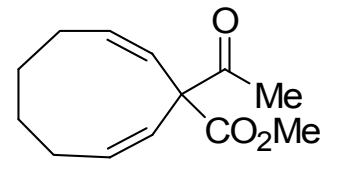

251

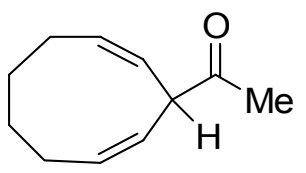

252 


\subsection{Heterocyclic substrates}

\subsubsection{From $\beta$-carbethoxy substituted lactones}

The demethoxycarbonylation of the methoxycarbonyl substituted furanone $\mathbf{2 5 3}$ to $\gamma$-lactone 254 $(72 \%)$ was accomplished on treatment with DMSO, $\mathrm{NaCl}$ and water $\left(160^{\circ} \mathrm{C}, 12 \mathrm{~h}\right) .{ }^{138}$

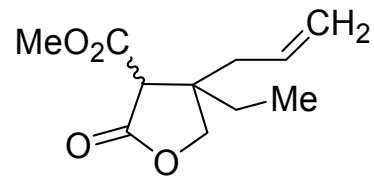

253

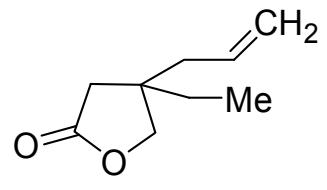

254

Decarbomethoxylation of $\gamma$-lactone 255 with DMSO, $\mathrm{NaCl}$ and water $\left(110^{\circ} \mathrm{C}, 12 \mathrm{~h}\right)$ yielded chiral (4S) 2-butyrolactone 256 (84\%) which in a series of subsequent transformations was transformed into the pentacyclic alkaloids (-)-eburnamonine and (+)-epi-eburnamonine. ${ }^{139 a, b}$

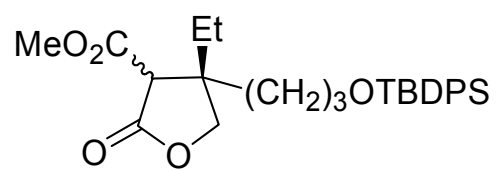

255

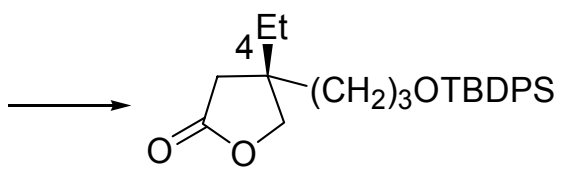

256

The demethoxycarbonylation of 257 in DMSO (or DMF), $\mathrm{NaCl}$ and water $\left(150^{\circ} \mathrm{C}, 3-5 \mathrm{~h}\right.$ ) yielded the lactone $258(75 \%){ }^{140}$
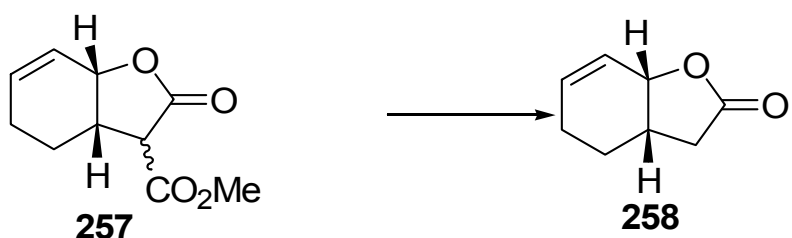

The silylated butenyl lactone 260 (77\%) was obtained by treatment of 259 with DMSO and $\mathrm{LiCl}$ (reflux, $3 \mathrm{~h}$ ). Further elaborations of the lactone and terminal silyl group were performed. ${ }^{141}$<smiles>CCOC(=O)C1(CC/C=C/[SiH2]C)CCOC1=O</smiles>

259<smiles>CC[SiH2]C=CCCC1CCOC1=O</smiles>

260

The deethoxycarbonylation of the fluorinated lactone $\mathbf{2 6 2}$ with $\mathrm{DMSO}, \mathrm{NaCl}$ and water (reflux, $2.5 \mathrm{~h}$ ) led to a diastereoisomeric mixture of lactones 263 (73\%) which in a few steps could be converted in 5-amino-2-fluorolevulinic acid. ${ }^{142}$ 


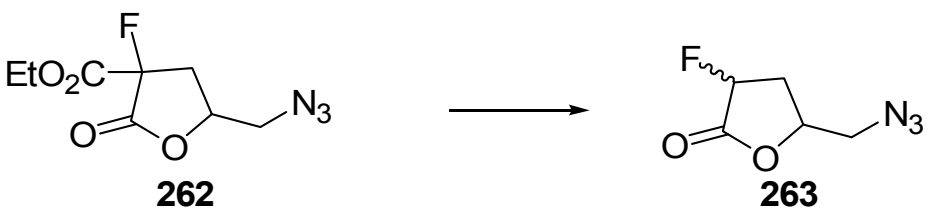

Of particular interest is the conversion of $\mathbf{2 6 4}$ to the naturally occurring racemic spirolactone andirolactone (265). Treatment of $\mathbf{2 6 4}$ with $\mathrm{DMSO}, \mathrm{NaCl}$ and water $\left(160^{\circ}, 2 \mathrm{~h}\right)$ afforded 265 $(90 \%)^{143}$<smiles>CC(=O)C1=C(C)C2(CC=C(C)CC2)OC1=O</smiles>

The lactone 266 on heating in $\mathrm{DMSO}, \mathrm{LiCl}$ and water $\left(125^{\circ} \mathrm{C}, 12 \mathrm{~h}\right)$ led to $(S)$-sotolon $(\mathbf{2 6 7})$ $\left(80 \%, 92 \%\right.$ ee), a volatile compound isolated from raw cane sugar. ${ }^{144}$

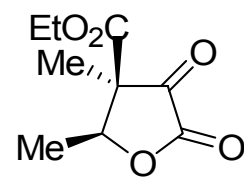

266

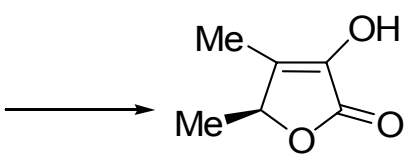

267

Treatment of lactone 268 with DMSO and water $\left(110-120^{\circ} \mathrm{C}, 1 \mathrm{~h}\right)$ led to $269(99 \%)$, which was used in the synthesis of potential phenolic antioxidants. ${ }^{145}$<smiles>CCOC(=O)C1C(=O)Oc2c(C)c(C)c(O)c(C)c21</smiles>

268<smiles>Cc1c(C)c2c(c(C)c1O)OC(=O)C2</smiles>

269

The synthesis of $(3 S, 4 S) 271(60 \%, 99.9 \%$ ee) was accomplished by treatment of 270 with DMSO, $\mathrm{LiCl}$ and water (reflux, $3.5 \mathrm{~h}$ ). This intermediate was used in a synthesis of the sex pheromones of pine sawflies. ${ }^{146}$<smiles>COC(=O)[C@H]1C(=O)OC(C)C1C</smiles>

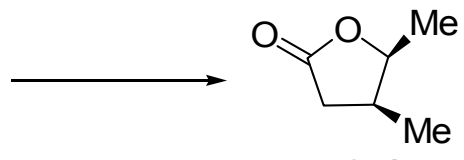

271 
The bicyclic lactone 272 on treatment with $\mathrm{DMSO}, \mathrm{LiCl}$ and water $\left(195^{\circ} \mathrm{C}, 3 \mathrm{~h}\right)$ led to the bicyclic lactone $273(64 \%){ }^{147}$

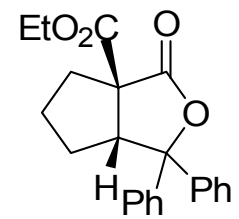

272

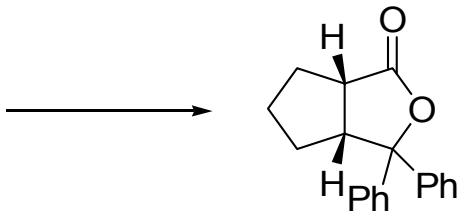

273

The $\alpha$-carbomethoxy- $\alpha$-hydroxy- $\gamma$-lactone 274 on treatment with $\mathrm{DMF}, \mathrm{NaCl}$ and water $\left(150^{\circ} \mathrm{C}, 3 \mathrm{~h}\right)$ led to $\mathbf{2 7 5 a}$ and $\mathbf{2 7 5 b}(84 \%, 68: 32$ ratio) which could be separated by chromatography. ${ }^{148}$

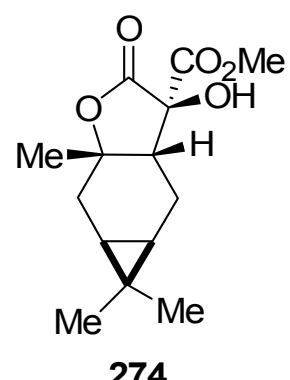

274
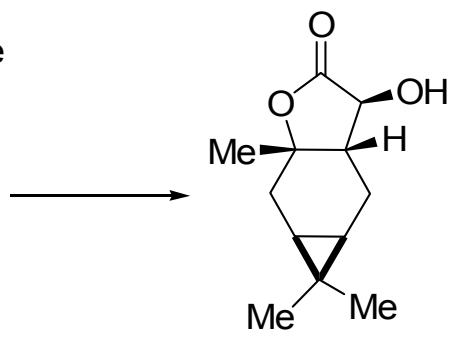

275a

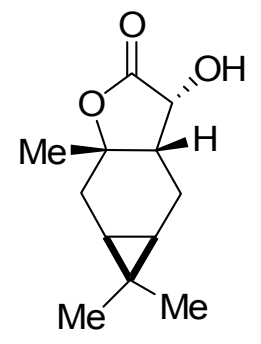

275b

The demethoxycarbonylation of 276 (a 3:1 mixture of diastereoisomers) with DMF and LiI (reflux) led to 277 (86\%) which in a subsequent series of reactions was used in an enantioselective total synthesis of $(+)$-methyl pederate. ${ }^{149}$<smiles>C=CC1C(C(C)=O)C(=O)OC(C)C1C</smiles>

276<smiles>C=CC1CC(=O)O[C@@H](C)[C@H]1CC</smiles>

277

The lactone 278 with $\mathrm{DMSO}, \mathrm{NaCl}$ and water $\left(150-160^{\circ} \mathrm{C}, 2 \mathrm{~h}\right)$ led to $279(75 \%)$. In a similar manner the $\beta$-methyl analogue was converted into the corresponding deethoxycarbonylated product. Other substituted analogues were also deethoxy-carbonylated. These derivatives were used in a synthesis of perhydrofuro[2,3-b]furan ring systems. ${ }^{150}$<smiles>C=C[C@H]1C[C@H](C)OC(=O)[C@H]1OCC</smiles>

278<smiles>C=C[C@H]1CC(=O)O[C@H](C)C1</smiles>

279 
Treatment of lactone $\mathbf{2 8 0}$ with $\mathrm{HMPA}, \mathrm{NaCl}$ and water $\left(190^{\circ} \mathrm{C}, 2.5 \mathrm{~h}\right)$ gave $281(65 \%) .{ }^{151}$

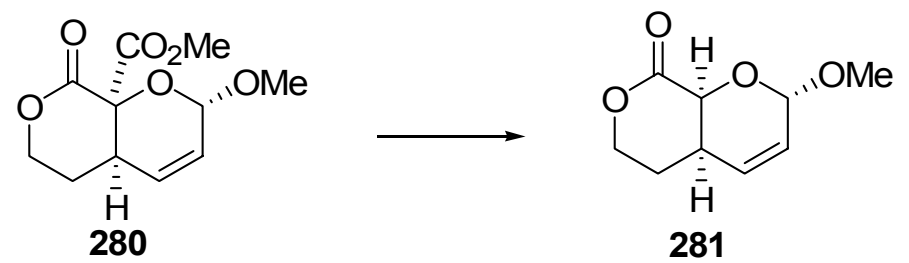

Treatment of 11-carbomethoxy-18-norestrane 282 with DMSO and $\mathrm{NaCN}\left(100^{\circ} \mathrm{C}, 19 \mathrm{~h}\right)$ led to racemic 283 (no yield given). ${ }^{152}$

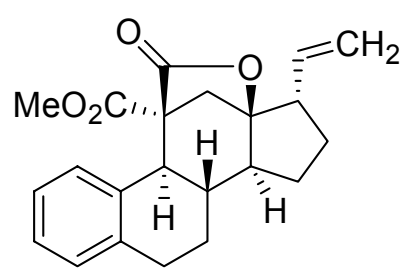

282<smiles>C=C[C@H]1CC[C@H]2[C@H]3CCc4ccccc4[C@H]3C(=O)O[C@@]21C</smiles>

283

The decarbomethoxylation of $\mathbf{2 8 4}$ on treatment with DMSO, and $\mathrm{NaCN}\left(90^{\circ} \mathrm{C}, 24 \mathrm{~h}\right)$ led to isomeric mixtures of $\mathbf{2 8 5 a}$ and $\mathbf{2 8 5 b}$ (78\%), which were used in a steroid analogue synthesis. ${ }^{153}$ A similar strategy was used for the incorporation of fluoro substitutent ${ }^{153}$ and a 3-hydroxy steroidal group. ${ }^{154}$

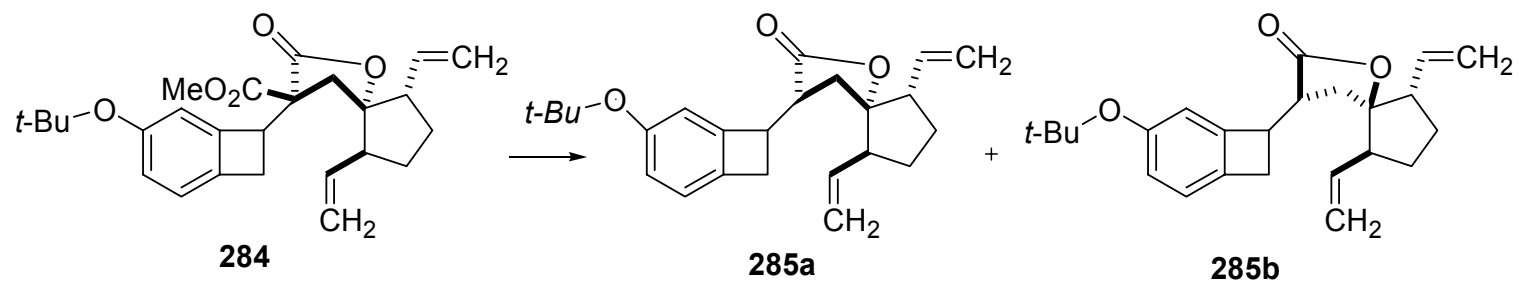

Treatment of 286a and 286b (diastereoisomeric mixture) with DMSO and $\mathrm{NaCN}\left(90^{\circ} \mathrm{C}, 24\right.$ h) led to an inseparable mixture of 4-azabenzocyclobutane diastereoisomers $287 \mathbf{a}$ and $287 \mathbf{b}$ $(91 \%)$ which were subsequentely converted into the aza steroidal analogues. ${ }^{155}$ 


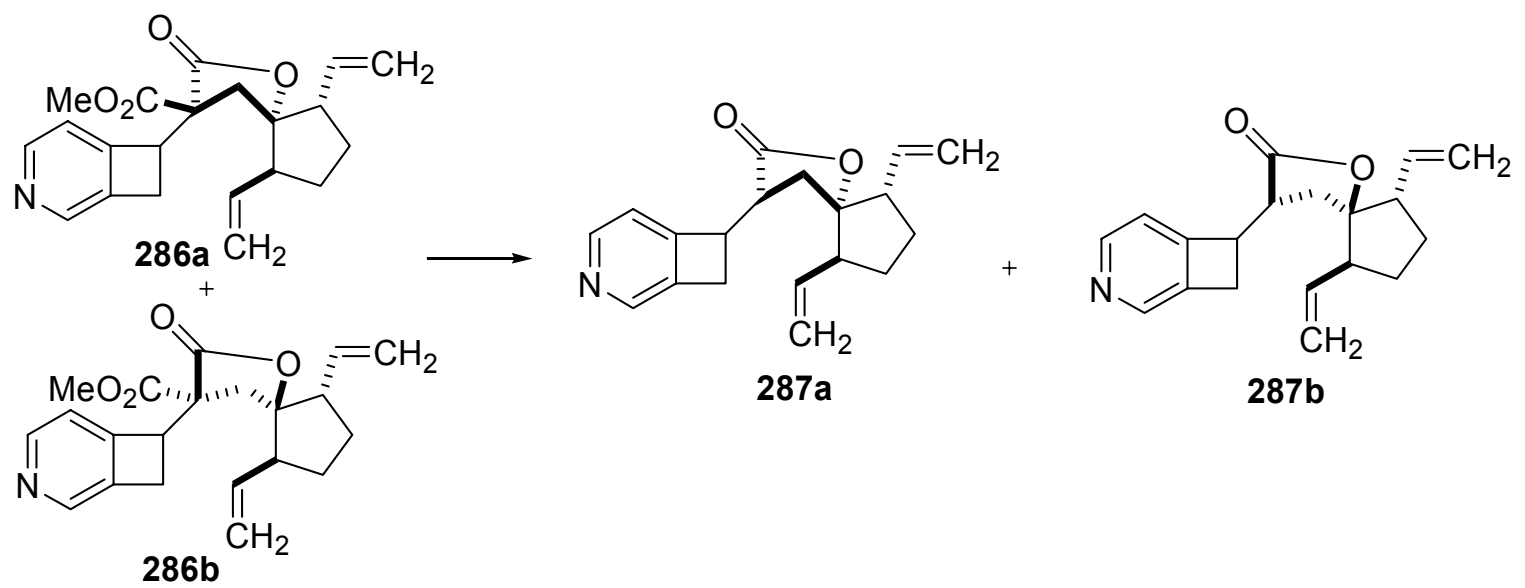

In the preparation of dihydroisoquinolines, the intermediate 289 was prepared by treatment of 288 (44\%) with $\mathrm{DMSO}, \mathrm{NaCl}$ and water $\left(145-150^{\circ} \mathrm{C}, 6 \mathrm{~h}\right) .{ }^{156}$<smiles>COC(=O)c1c(OC)nc(C)c2c1CCC(C)C2=O</smiles>

The ester 290 on treatment with $\mathrm{DMF}, \mathrm{LiCl}$ and water $\left(92^{\circ} \mathrm{C}, 16 \mathrm{~h}\right)$ led to compound 291 $(78 \%)$ as an epimeric mixture which could not be separated. ${ }^{157}$<smiles>C=CCCC[C@H]1NC(=O)[C@@H]2CCCN2C(=O)[C@H]1CCCCC</smiles>

The thieno[2,3-d]pyrimidin-4-one (292) on treatment with DMSO, $\mathrm{LiCl}\left(150^{\circ} \mathrm{C}\right)$ led to the pyrimidinone 293(no experimental conditions). ${ }^{158}$<smiles>CCOC(=O)c1nc2sc(CC)cc2c(=O)[nH]1</smiles> 
The use of $\mathrm{MgCl}_{2}$ hexahydrate (in place of $\mathrm{NaCl}$ ) in DMSO $\left(130-140^{\circ} \mathrm{C}, 2.5 \mathrm{~h}\right.$ ) for the demethocycarbonylation of $\mathbf{2 9 4}$ led to deoxybrevianamide 295 (59\%) along with the corresponding epimer (38\%). ${ }^{159}$

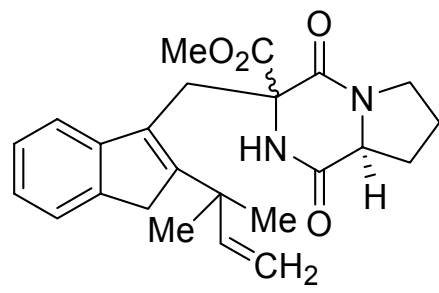

294

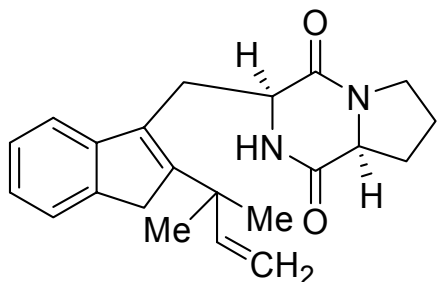

295

The dealkoxycarbonylations of $\beta$-keto esters using halides of group IIa metals have been studied. For example, treatment of 296 with $\mathrm{MgCl}_{2}$ hexahydrate or $\mathrm{CaCl}_{2}$ dihydrate in DMSO (in the presence of $\mathrm{PhSH}$, at $150-160^{\circ} \mathrm{C}$ ) led to $297(50-60 \%) .{ }^{160}$<smiles>CCOC(=O)C1(C(=O)C(=O)N2CCc3ccccc3C23CCCCC3)CCCCC1</smiles>

296<smiles></smiles>

297

The deethoxycarbonylation of substituted derivatives such as $\mathbf{2 9 8}$ have been accomplished using $\mathrm{MgCl}_{2}$ hexahydrate in DMSO (or HMPA) in the presence of $\mathrm{PhSH}\left(150-155^{\circ} \mathrm{C}, 2 \mathrm{~h}\right.$ ) to yield 299 (73\%). These derivatives were used in a synthesis of erythrina and related alkaloids. ${ }^{161}$<smiles>CCOC(=O)C1CCCCC12c1cc(OC)c(OC)cc1CCN2C(=O)CO</smiles>

298<smiles>COc1cc2c(cc1OC)C1(CCCCC1)C(O)=C(O)C2=O</smiles>

299

The decarbomethoxylation of $\mathbf{3 0 0}$ with $\mathrm{DMSO}, \mathrm{NaCl}$ and water $\left(135-140^{\mathrm{O}} \mathrm{C}, 5-8 \mathrm{~h}\right)$ led to the ketones 301 (49-90\%). Intermediate 301c was converted into racemic $\alpha$-lipoic acid. ${ }^{162}$

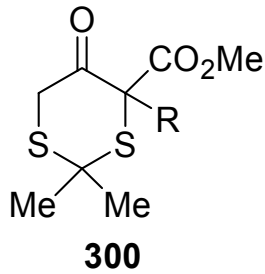

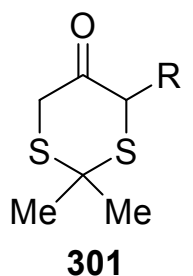

301

a, $\mathrm{R}=n$-butyl; b, $\mathrm{R}=$ benzyl: $\mathrm{c}, \mathrm{R}=\left(\mathrm{CH}_{2}\right)_{4} \mathrm{CO}_{2} \mathrm{Me} ; \mathrm{d}, \mathrm{R}=$ allyl; e, $\mathrm{R}=\mathrm{Et}$ 
Treatment of 302 with HMPA and $\mathrm{LiCl}\left(65-75^{\circ} \mathrm{C}, 20 \mathrm{~h}\right)$ led to $303(65 \%)$, which was used in a synthesis of 2-alkyl-3-cyclopentenones. ${ }^{163}$<smiles>CCCCCC1CSCCC1=O</smiles>

In a study of routes to thiathromboxane analogues, the dealkoxycarbonylations of a number of 3-methyoxycarbonyl- 3-substituted thiin-4-ones were evaluated. Treatment of 304 with DMF, anhydrous $\mathrm{MgCl}_{2}$ and a phosphate buffer $\left(160^{\circ} \mathrm{C}, 21 \mathrm{~h}\right)$ led to enone $305(69 \%)$ as an inseparable mixture of the 2,3-trans and 2,3-cis isomers along with $16 \%$ of the corresponding desilylated products, namely the 2,3-trans and 2,3-cis alcohols. ${ }^{164}$<smiles>CCCCCC(/C=C/C1SC=CC(=O)C1(COC)OC(C)=O)OCC</smiles>

304<smiles>[R5]OC(/C=C/C1SC=CC(=O)[C@H]1C/C=C/CCCC(C)=O)CCCCC</smiles>

305

Treatment of 306 with DMF and $\operatorname{LiBr}\left(137^{\circ} \mathrm{C}, 5 \mathrm{~h}\right)$ in the presence of $p$-aminothiophenol (a trap for $\mathrm{MeBr}$ formed during the reaction) gave the demethoxycarbonylated product 307 (96\%) with less than $3 \%$ of the corresponding trans-isomer. Initial attempts to use only DMF and LiI led to $\mathbf{3 0 7}$ along with $30 \%$ of the corresponding N-methyl analogues. Intermediate $\mathbf{3 0 7}$ was utilized in the preparation of analogues related to diltiazem used in the treatment of hypertension. ${ }^{165}$
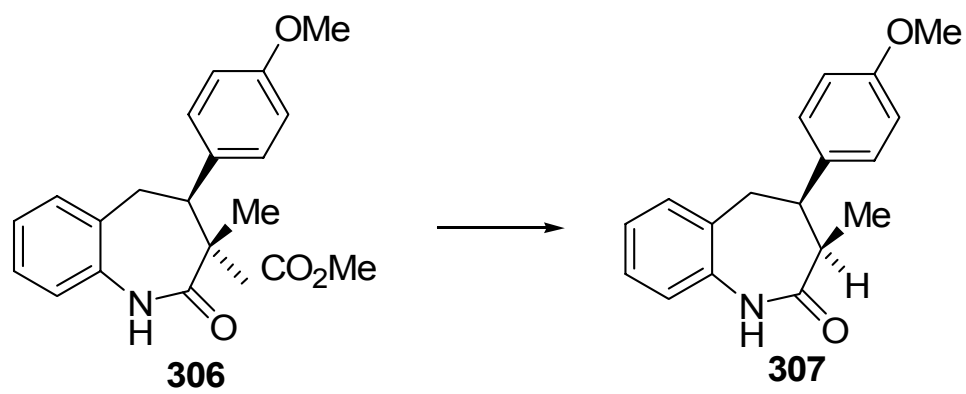

Upon heating 308 in dry $\mathrm{HMPA}$ and $\mathrm{LiCl}\left(120^{\circ} \mathrm{C}, 10 \mathrm{~min}\right)$ the demethoxycarbonylation led to the intramolecular cyclization product $\mathbf{3 0 9}(61 \%) .{ }^{166}$ 


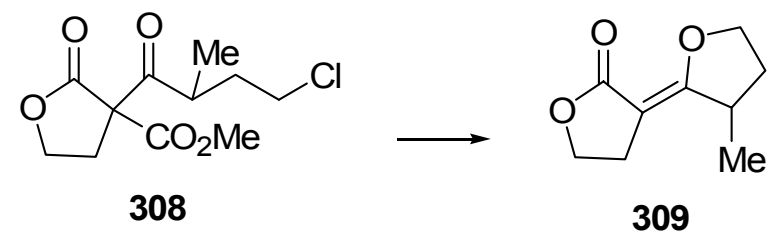

Table 2 lists some additional examples.

Table 2. Dealkoxycarbonylations of disubstituted $\beta$-keto esters

Starting Material

\subsection{1,3-Diones}

\subsubsection{From substituted 2-carbalkoxy-1,3-diones}

A wide variety of $\beta$-diketones (for identification of potential secretions from the paracloacal glands of alligator and caimans) have been prepared by treatment of substituted 2-carbalkoxy1,3-diones with $\mathrm{NaCl}$ and water at reflux $(12 \mathrm{~h})$. The following reaction sequence for the preparation of 5-ethylnonane-2,4-dione (311) from the corresponding $\beta$-2-carethoxy-1,3-dione is illustrative $310(62 \%) .{ }^{171}$<smiles>CCCCC(CC)C(=O)CC(=O)NCCCCC(CC)C(=O)C(OCC)C(C)=O</smiles> 
The synthesis of a wide variety of $\beta$-diketones found in sunflower pollen has been accomplished. For example, the conversion of $\mathbf{3 1 2}$ with DMSO, $\mathrm{NaCl}$ and water (reflux, $8 \mathrm{~h}$ ) led to $313(40-60 \%){ }^{172}$<smiles>CCOC(=O)C(C(=O)OCC)C(=O)c1ccccc1</smiles>

312

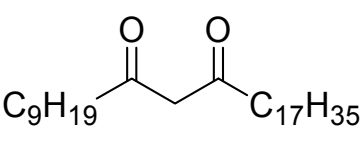

313

Treatment of enol $\mathbf{3 1 4}$ with DMSO, $\mathrm{NaCl}$ and water (reflux, $18 \mathrm{~h}$ ) led to ketone 315 $(62 \%){ }^{173}$<smiles>[M]C1CCC[C@H]2C[C@]1(C)[C@@H](C(C)=O)C(O)=C2C(=O)OC</smiles>

314

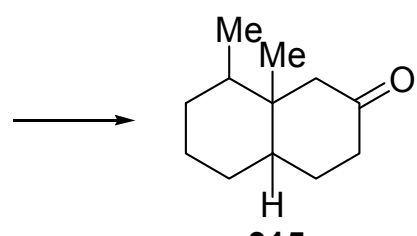

315

The facile demethoxycarbonylations of 316a $(\mathrm{n}, \mathrm{m}=6)$ and $316 \mathbf{b}(\mathrm{n}=6, \mathrm{~m}=20)$ were accomplished by heating in DMSO and water to yield the corresponding long-chain 1,3-diones $\mathbf{3 1 7} \mathbf{a}(82 \%)$ and $\mathbf{3 1 7 b}(98 \%){ }^{174}$

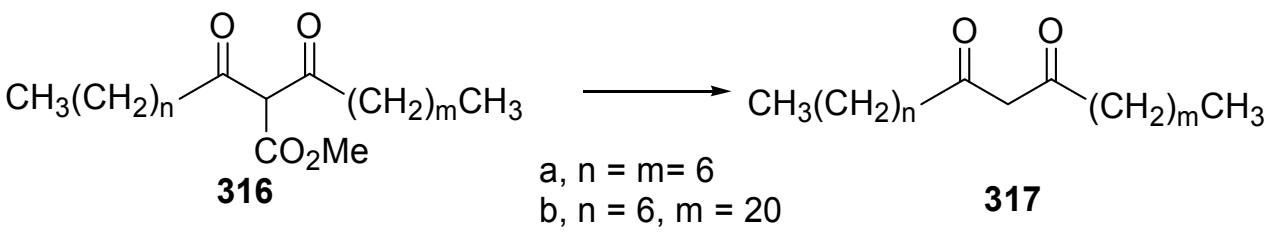

Treatment of 318 with DMSO, NaCl, water ( reflux, $8 \mathrm{~h}$ ) led to the 1,3-dione 319 in good yield. $^{175}$

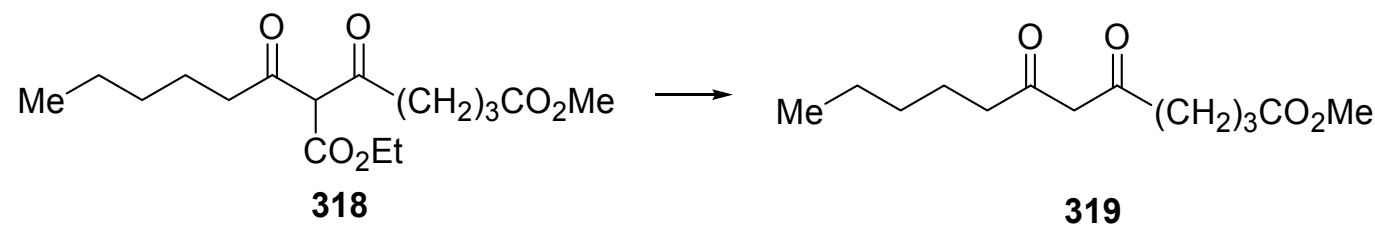

Treatment of the enolic tautomer 320 with DMSO, $\mathrm{NaCl}$ and $\mathrm{H}_{2} \mathrm{O}\left(160-170^{\circ} \mathrm{C}, 4 \mathrm{~h}\right)$ led to the enolic form of the 1,3-dione $321(54 \%){ }^{176}$ 
<smiles>COC/C(C(=O)CCc1ccc(OC)cc1)=C(O)\C=C\c1ccc(OC)cc1</smiles>

Treatment of $\mathbf{3 2 2}$ with DMSO, $\mathrm{NaCl}$ and water (reflux, $1 \mathrm{~h}$ ) led to $\mathbf{3 2 3 .}{ }^{177}$<smiles>CCC1=C(C)C(=O)C(C(C)=O)C1=O</smiles>

The ester 324 in acetonitrile and water was refluxed for $2.5 \mathrm{~h}$ to yield $\mathbf{3 2 5}(95 \%) .{ }^{178}$

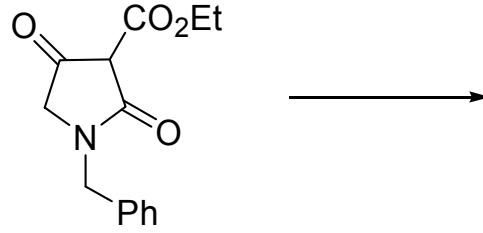

324

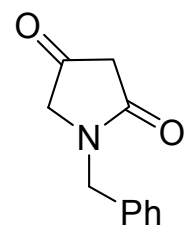

325

\subsection{1,4-Diones}

\subsubsection{From $\alpha$-carbalkoxy-1,4-diones}

The demethoxycarbonylation of $\mathbf{3 2 6}$ with $\mathrm{DMSO}, \mathrm{NaCl}$ and water $\left(160-170^{\circ} \mathrm{C}, 6 \mathrm{~h}\right)$ led to 1,4dione $327(40 \%){ }^{179}$<smiles>COC(=O)C(CC(=O)c1ccccc1)C(C)=O</smiles>

326<smiles>CC(=O)CCCC(=O)CCC(=O)c1ccccc1</smiles>

327

Treatment of the $\beta$-keto ester 328 with DMSO, $\mathrm{NaCl}$ and water $\left(110^{\circ} \mathrm{C}, 2.5 \mathrm{~h}\right)$ led to 1,1,1trifluoro-2,5-hexanedione 329 (73\%). ${ }^{180}$<smiles>CCOC(=O)C(CC(C)=O)C(=O)C(F)(F)F</smiles><smiles>CC(=O)CCC(=O)C(F)(F)F</smiles> 
The deethoxycarbonylations of $\beta$-keto esters 330a-c in DMSO, $\mathrm{NaCl}$ and water $\left(180^{\circ} \mathrm{C}, 20 \mathrm{~h}\right)$ led to good yields of the corresponding 1,4-diones 331a-c (48-75\%). ${ }^{181}$<smiles>[R]C(=O)CCC([R19])C(=O)CC(C)(C)C(=O)OCC</smiles>

$\mathrm{a}, \mathrm{R}=\mathrm{Me} ; \mathrm{b}, \mathrm{R}=\mathrm{Ph}, \mathrm{c}, \mathrm{R}=\mathrm{C}_{3} \mathrm{H}_{7}$

\subsection{1,5-Dione}

\subsubsection{From $\alpha$-carbomethoxy substituted substrate}

The decarbomethoxylation of $\beta$-keto ester 332 was accomplished using DMPU and $\mathrm{LiCl}$ $\left(120^{\circ} \mathrm{C}, 7 \mathrm{~h}\right)$ to afford $(R)-333(72 \%)$. It was noted that the use of HMPA or DMSO as solvents did not give satisfactory yields. The RCM macrocyclization of this keto diene led to the 15membered carbocyclic substrate which was converted into $(R)-(+)$-muscopyridine. ${ }^{182}$<smiles>C=CCCCCC(=O)[C@H](CCC(=O)C[C@H](C)CC=C)C(C)=O</smiles><smiles>C=CCCCCC(=O)CCCC(=O)CC(C)CC=C</smiles>

\section{7. $\beta$-Keto ester and malonate ester polyfunctional substrates}

Treatment of 334 with DMSO, $\mathrm{NaCl}$ and water $\left(173^{\circ} \mathrm{C}, 45 \mathrm{~min}\right)$ led to $335(65 \%)$, resulting from the decarbomethoxylation of the malonate ester group and the $\beta$-keto ester group. ${ }^{183}$<smiles>COC(=O)CCC(C)=CCCC(C)=O</smiles>

Compound 336 in DMF, $\mathrm{LiCl}$ and water (reflux, $18 \mathrm{~h}$ ) led to $337 \mathbf{a}(36 \%)$ and $\mathbf{3 3 7 b}$ $(25 \%)^{184}$

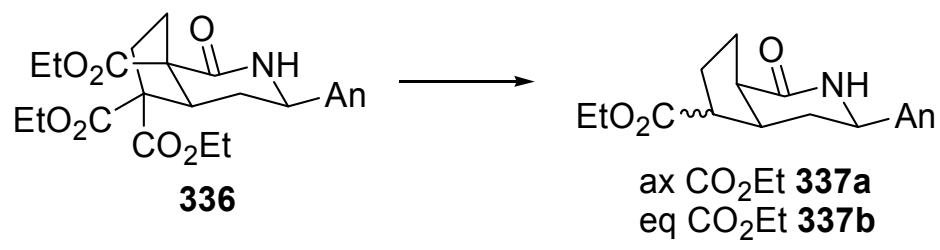

Treatment of 338 with DMSO, $\mathrm{NaCl}$ and water $\left(155-160^{\circ} \mathrm{C}\right)$ led to $339(61 \%) .{ }^{185}$ 


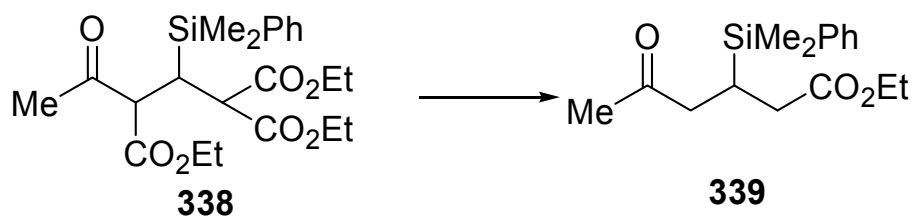

Upon heating 340 in DMSO, $\mathrm{NaCl}$ and water $\left(150-160^{\circ} \mathrm{C}, 2 \mathrm{~h}\right) \mathbf{3 4 1}$ was formed $(83 \%)$, the product of a deethoxycarbonylation of the $\beta$-keto ester functionality. If diester $\mathbf{3 4 1}$ is heated with DMSO, $\mathrm{LiCl}$ and water with a small amount of pyridine $\left(150-160^{\circ} \mathrm{C}, 14 \mathrm{~h}\right), \mathbf{3 4 2}(72 \%)$ was obtained. Heating diester 340 with DMSO, $\mathrm{LiCl}$ and water $\left(150-160^{\circ} \mathrm{C}, 14 \mathrm{~h}\right)$ and a small amount of pyridine afforded $342(70 \%){ }^{186}$<smiles>CCOC(=O)C1CC(C(=O)OCC)(C(=O)OCC)CCC1=O</smiles><smiles>CCOCC1(OCC)CCC(=O)CC1</smiles><smiles>CCOC(=O)C1CCC(=O)CC1</smiles>

\subsection{Aldehyde}

\subsubsection{From $\alpha$-methoxycarbonyl aldehyde}

Treatment of $\mathbf{3 4 3}$ with DMF and LiI hydrate (reflux, $1 \mathrm{~h}$ ) led to racemic $344(89 \%) .{ }^{187}$<smiles>COC(=O)C(C=O)C1CCCCC1[14CH2]C=O</smiles>

\subsection{Nitriles}

The dealkoxycarbonylation of an $\alpha$-cyano ester is a useful preparative route leading to nitriles.

\subsubsection{From $\alpha$-cyano esters}

\subsubsection{From mono substituted substrates}

The conjugate addition product obtained by addition of methyl cyanoacetate to 4-phenyl-3buten-2-one using a chiral(salen)Al complex led to $\mathbf{3 4 5}$ which on treatment with DMSO and water $\left(130^{\circ} \mathrm{C}\right.$ ) led to $\mathbf{3 4 6}$ ( $85 \%$ for two steps in $93 \%$ ee). ${ }^{188}$<smiles>COC(=O)C(CC(C)=O)C(C#N)C(C)C(C)=O</smiles> 
The chemoselective deethoxycarbonylation of $\alpha$-cyano ester 347 was accomplished by treatment with DMSO, water and $\mathrm{LiCl}\left(140^{\circ} \mathrm{C}, 4 \mathrm{~h}\right)$ to yield $348(75 \%) .{ }^{189}$<smiles>CCOC(=O)CC(CC(=O)OCC)C(CC(=O)OCC)CC(CC)OCC</smiles>

The deethoxycarbonylation of $\alpha$-cyano ester 349 was accomplished by treatment with DMSO, water and $\mathrm{NaCl}$ (reflux, $20 \mathrm{~h}$ ) to afford 350 (48\%). ${ }^{190}$<smiles>CCOC(C#N)CCC(=O)c1ccccc1</smiles><smiles>C</smiles><smiles>N#CCCCC(=O)c1ccccc1</smiles>

350

Treatment of 351 with DMSO, $\mathrm{LiCl}\left(130^{\circ} \mathrm{C}, 5 \mathrm{~h}\right)$ led to $352(75 \%) .{ }^{191}$<smiles>CCCCCOc1cccc(C(C)(C)C(C#N)C(=O)OCC)c1</smiles>

Treatment of the diester 353 with $\mathrm{DMSO}, \mathrm{NaCl}$ and water $\left(140^{\circ} \mathrm{C}, 2.5 \mathrm{~h}\right)$ led to the deethoxycarbonylation of the ester group attached to the carbon holding the cyanide group to afford 354 (77\%). The ester was subsequently converted into the corresponding pyrrolidone. ${ }^{192}$<smiles>CCOC(=O)C(C#N)C(Cc1ccccc1)C(=O)OCC</smiles>

353<smiles>CCOC(=O)C(CC#N)Cc1ccccc1</smiles>

Treatment of 355 with DMSO, $\mathrm{NaCl}$ and water $\left(160^{\circ} \mathrm{C}, 4 \mathrm{~h}\right)$ led to nitrile $356(65 \%){ }^{193}$

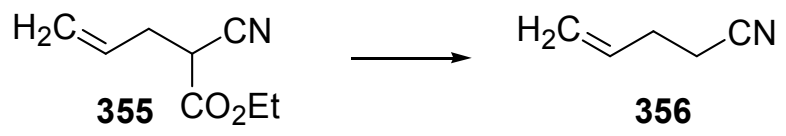

Treatment of cyano ester 357 with DMSO, $\mathrm{NaCl}$ and $\mathrm{H}_{2} \mathrm{O}\left(160^{\circ} \mathrm{C}, 3 \mathrm{~h}\right)$ led to $358(82 \%) .{ }^{194}$ 


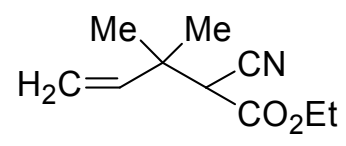

357

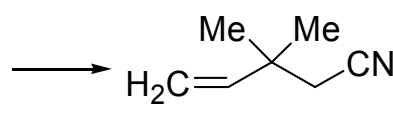

358

The decarbomethoxylations of 359a (64\%ee) and 359b (96\%ee) with DMSO, water and $\mathrm{NaCl}$ (reflux, $4 \mathrm{~h}$ ) led to the enantioselective synthesis of 360a (74\%) and 360b (80\%), respectively. ${ }^{195}$

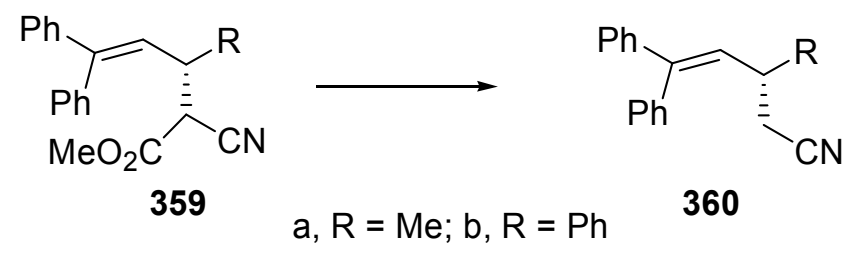

Homo- and copolymers of CNEVE 361 were deethoxycarbonylated by heating in DMSO in the presence of $\mathrm{NaCl}$ to yield poly(vinyl ethers) with 2-cyanopropoxy side chains $\mathbf{3 6 2}$. ${ }^{196}$
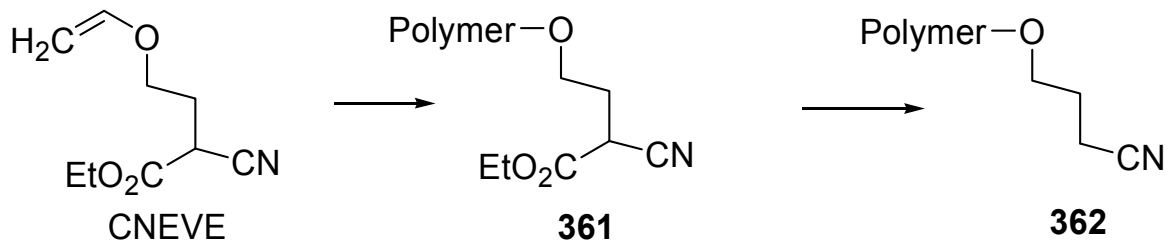

Treatment of $\alpha$-cyano ester 363 (89\%ee) with DMSO, water and $\mathrm{NaCl}\left(130^{\circ} \mathrm{C}, 24 \mathrm{~h}\right)$ led to chemoselective removal of the carbomethoxyl group $\alpha$ to the cyano group to afford $\mathbf{3 6 4}$ (89\%ee) without loss of sterochemistry. ${ }^{197}$
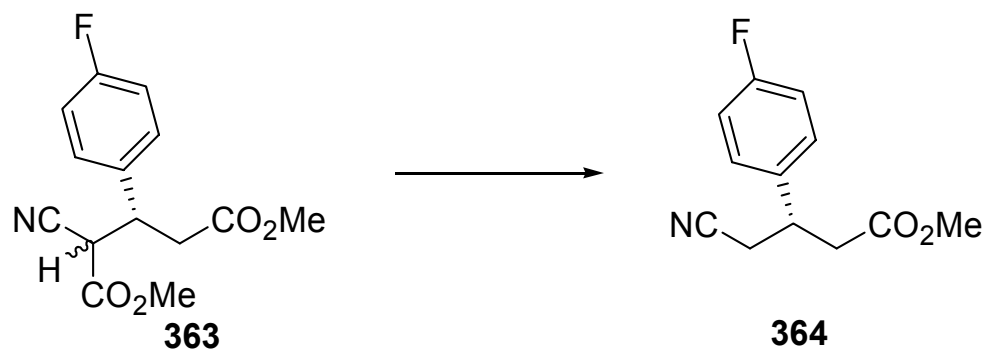

Analogue $(2 S, 4 R)-365$ on heating with DMSO, $\mathrm{NaCN}$ and water $\left(140^{\circ} \mathrm{C}, 1 \mathrm{~h}\right)$ led to 366 $(67 \%) .{ }^{198}$ 
TBSO,

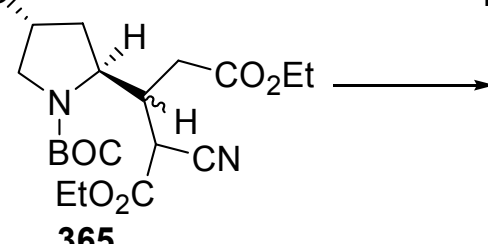

365
TBSO,<smiles>CCOC(=O)C[C@H](CC#N)[C@H]1CCCN1C(=O)O</smiles>

366

The deethoxycarbonylation of nitrile ester 367 was accomplished using DMSO, $\mathrm{LiCl}$ and water $\left(150^{\circ} \mathrm{C}, 1 \mathrm{~h}\right)$ to yield nitrile $368(84 \%) .{ }^{199}$<smiles>CCC[C@H](C(C)C)C(CCC=C(C)C)C(C)C(=O)OCC</smiles><smiles>CCC(CCC=C(C)C)[C@H](CC)C1CCC(C)=C(C)C1=O</smiles>

Treatment of the oxindole 369 with DMSO, $\mathrm{NaCN}$ and water $\left(160^{\circ} \mathrm{C}, 2 \mathrm{~h}\right)$ led to $370(80 \%)$ with decarbomethoxylation of the ester functionality and the $\mathrm{N}-\mathrm{CO}_{2} \mathrm{Me}$ group. This intermediate was converted into racemic physostigmine in a subsequent series of steps. ${ }^{200}$

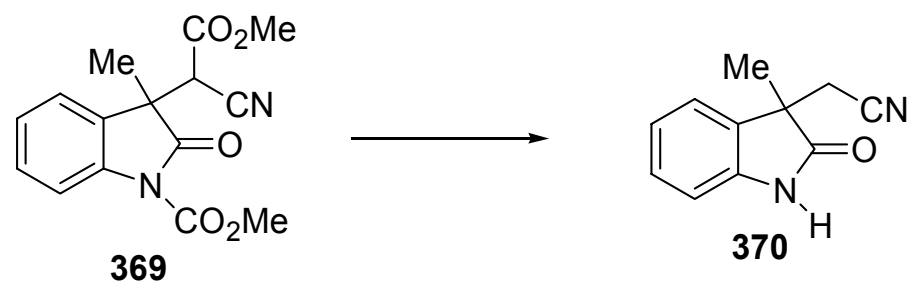

The lactonization of 371 to yield racemic $372(70 \%$, cis-trans fused ratio 4:1) was accomplished by heating in DMSO and water and additional $\mathrm{NaCN}\left(100^{\circ} \mathrm{C}, 0.5 \mathrm{~h}\right) .{ }^{201} \mathrm{In}$ this case, lactonization is faster then the expected Krapcho demethoxycarbonylation..

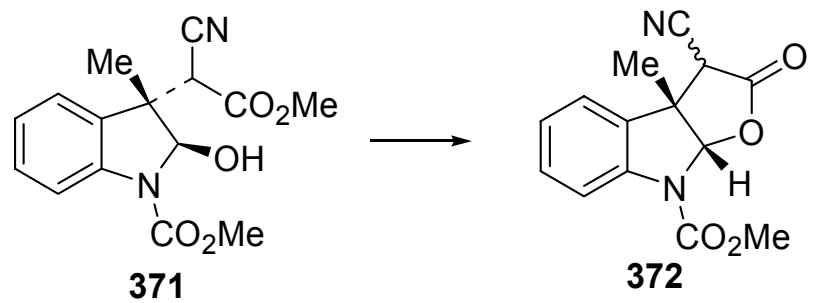

The N-benzyl protected analogue $\mathbf{3 7 3}$ on treatment in $\mathrm{DMF}, \mathrm{LiCl}$ and water (no experimental conditions) led to 374. This compound could readily be converted into the hexahydroazocino[4,5-b] indole on catalytic hydrogenation. ${ }^{202}$ 


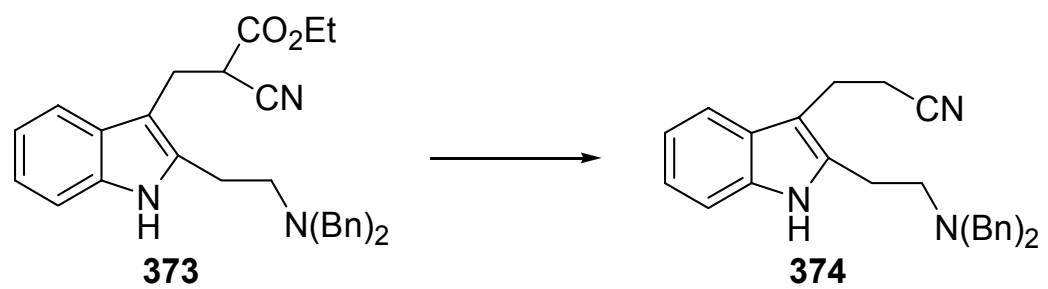

The $\alpha$-cyano acid 375 on treatment with $\mathrm{DMF}$ and $\mathrm{NaCl}$ in water $\left(125^{\circ} \mathrm{C}, 2.5 \mathrm{~h}\right)$ led to the decarboxylated product $376(91 \%){ }^{203}$<smiles>COc1cc2c(OC)cccc2cc1CCC(C#N)C(=O)OCc1cc2cccc(OC)c2cc1OC</smiles>

Treatment of the substituted cholesterol 377 with DMSO, $\mathrm{LiCl}$ and water $\left(140^{\circ} \mathrm{C}, 20 \mathrm{~h}\right)$ led to the $7 \beta$-(2-cyanoethyl) analogue $378(84 \%)$, the product of a de-t-butoxycarbonylation. ${ }^{204}$<smiles>CC(C)CCCC(C)C1CCC2C3C(CC#N)C=C4C[C@@H](OC(C)(C)C)CCC4(C)C3CC[C@]12C</smiles>

The deethoxycarbonylation of $\mathbf{3 7 9}$ with $\mathrm{DMSO}, \mathrm{NaCl}$ and water $\left(160^{\circ} \mathrm{C}, 2 \mathrm{~h}\right)$ led to nitrile $380(91 \%){ }^{205}$

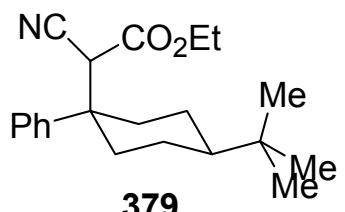

379

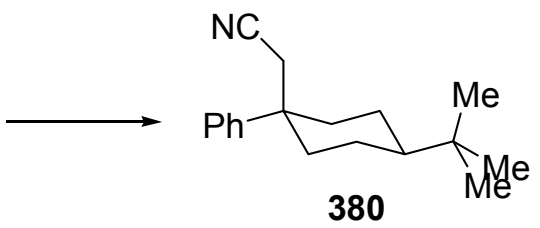

380

In the preparation of ${ }^{13} \mathrm{C}$-labelled substrates, treatment of the phthalimido analogue $\mathbf{3 8 1}$ with DMSO, $\mathrm{NaCl}$ and water (no conditions or yield) led to $\mathbf{3 8 2} .^{206}$<smiles></smiles>

381

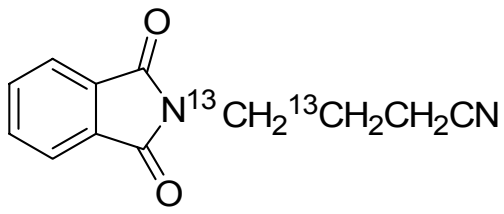

382 
In a route to the antibiotic anticapsin, the intermediate $384(73 \%)$ was prepared by deethoxycarbonylation of racemic 383 with DMSO, LiCl, water (reflux, 6 h). ${ }^{207}$

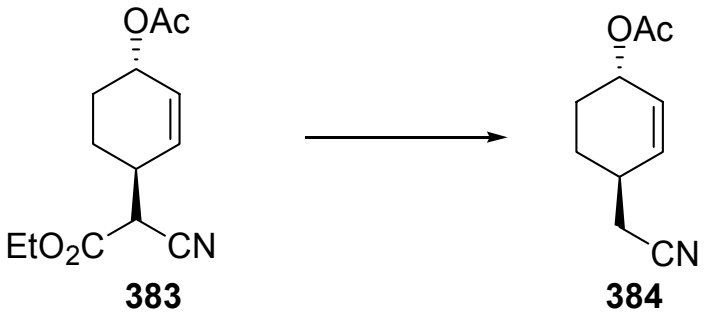

Treatment of $\mathbf{3 8 5}$ with $\mathrm{DMSO}, \mathrm{NaCl}$ and water $\left(165^{\circ} \mathrm{C}\right)$ led to cyano ester $\mathbf{3 8 6}$ and cyanolactone 387 (72- 78\%, 1:1 ratio) with the removal of the $t$-butoxy group as well as deprotection of the MOM ether. This intermediate was converted into the AB ring system of sesbanamide. $^{208}$<smiles>CCC(CC(C)=O)[C@H]1OCO[C@H](CSc2ccccc2)[C@H]1O</smiles>

\subsubsection{From disubstituted substrates}

The pentafluoro $\alpha$-cyano ester 388 on treatment with DMSO and water $\left(160^{\circ} \mathrm{C}, 120 \mathrm{~h}\right.$, or for shorter times in aqueous DMSO containing $\mathrm{NaCl})$ led to nitrile $\mathbf{3 8 9}(78 \%){ }^{209}$<smiles>CCOC(C#N)(CC)c1c(F)c(F)c(F)c(F)c1F</smiles><smiles>CCC(C#N)c1c(F)c(F)c(F)c(F)c1F</smiles>

389

Treatment of the cyano acid 390 with $\mathrm{DMSO}, \mathrm{LiCl}$ and water (in the presence of $\mathrm{NaHCO}_{3}$ ) at $165^{\circ} \mathrm{C}$ for $4.5 \mathrm{~h}$ led to the decarboxylation to give the cyclopropane nitriles 391 and 392 as a 55:45 mixture $(60 \%)$. These derivatives were used in the synthesis of the acid component of insecticidal pyrethoids. ${ }^{210}$

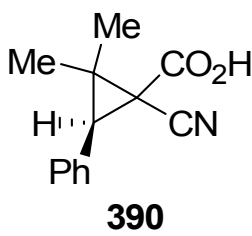

390

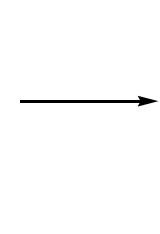<smiles>CC1(C)[C@@H]([PbH])[C@H]1C#N</smiles>

391<smiles>C[C@H](C#N)[C@@H]1[C@@H](c2ccccc2)C1(C)C</smiles> 
The demethoxycarbonylation of 393 with DMSO, $\mathrm{LiCl}$ (7 equivalents) and water (7 equivalents) in the presence of $\mathrm{NaHCO}_{3}$ (2 equivalents) $\left(165^{\circ} \mathrm{C}, 0.5 \mathrm{~h}\right)$ led to a $5: 1$ mixture of cis- and trans stereoisomers 394 and 395. The product isomer ratio was dependent on the molar equivalents of the reagents. ${ }^{211}$<smiles>COC[C@@H]1[C@@H](C)C(C)(C)[C@@H]1C(OC)OC</smiles>

393<smiles>COC(=O)C1C(C#N)C1(C)C</smiles>

394<smiles>COC(=O)C1C(C)C(C)C1(C)C</smiles>

395

The decarbomethoxylation of the cyano cyclobutane 396 with DMSO, $\mathrm{NaCl}$ and water $\left(150^{\circ} \mathrm{C}, 4 \mathrm{~h}\right)$ led to a mixture of cis- and trans-isomers $397(77 \%) .^{212}$

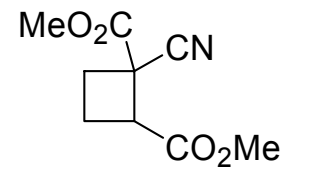

396

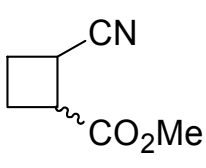

397

In the enantioselective synthesis of 11-keto steroids, treatment of a mixture of isomers 398 with $\mathrm{DMF}$ and $\mathrm{LiI}\left(140^{\circ} \mathrm{C}, 40 \mathrm{~h}\right.$ ) led to the demethoxycarbonylation product 399 (no yield recorded). ${ }^{213}$<smiles>C=CC[C@@H]1CC(C)(C#N)CC2(C)C1CCC21OCCO1</smiles><smiles>C=CC[C@H]1C[C@@H](C#N)C[C@]2(C)C1CCC21OCCO1</smiles>

The transannular Diels-Alder reaction and demethoxycarbonylation of macrocycle $\mathbf{4 0 0}$ yielded 401 as a diastereoisomeric mixture (89\%) was accomplished by treatment with $\mathrm{NaCN}$ and DMSO $\left(160^{\circ} \mathrm{C}, 8 \mathrm{~h}\right)$ followed by an aqueous workup. ${ }^{214}$ Treatment of $\mathbf{4 0 2}$ with $\mathrm{NaCN}$ and DMSO $\left(160^{\circ} \mathrm{C}, 8 \mathrm{~h}\right)$ followed by water gave $403(97 \%){ }^{214}$<smiles>COC(=O)/C=C/C=C/C=C/C(CCC/C=C\CC(C)(C#N)OC)OC</smiles><smiles>CO[C@H]1CCC[C@H]2[C@H]3C[C@@H](C#N)C[C@H]3C=C[C@H]12</smiles> 

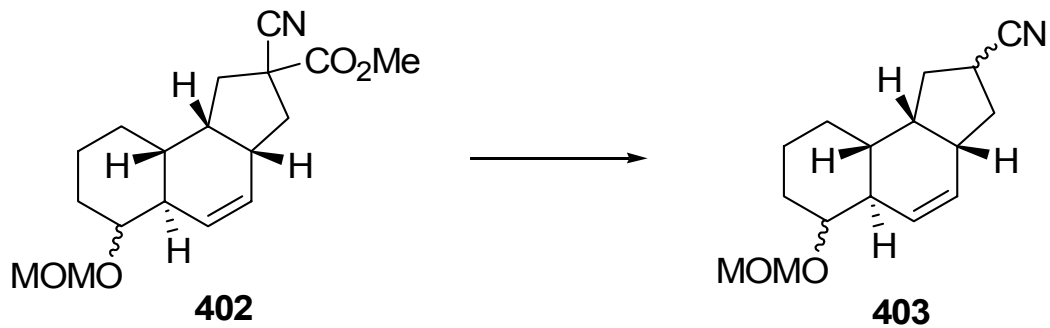

The deethoxycarbonylation and aromatization of dihydrocarbazole 404 with DMSO, LiCl and water $\left(100^{\circ} \mathrm{C}, 26 \mathrm{~h}\right)$ led to $405(45 \%) .{ }^{215}$
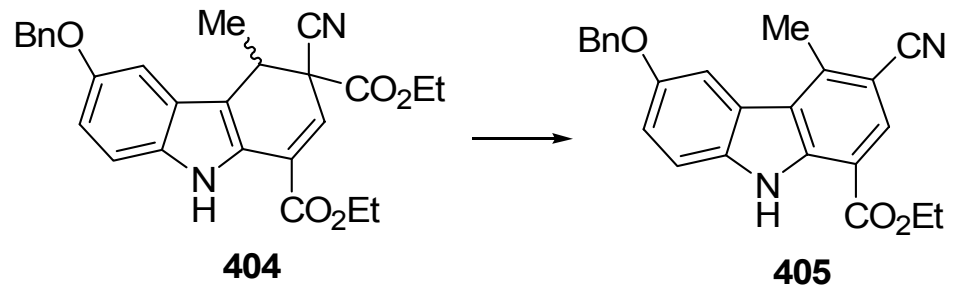

Treatment of $\alpha$-cyano ester 406 with $\mathrm{DMF}, \mathrm{NaCN}\left(160^{\circ} \mathrm{C}, 4 \mathrm{~h}\right)$ led to an epimeric racemic mixture of $\mathbf{4 0 7}$ and $\mathbf{4 0 8}(63 \%)$ in a 2:1 ratio. $^{216}$

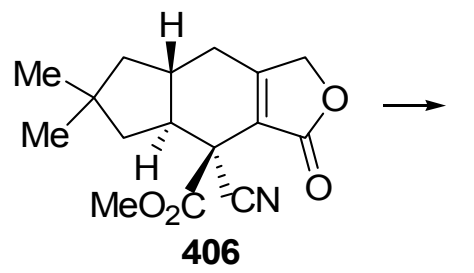<smiles>CC1(C)C[C@@H]2CC3=C(C(C#N)[C@@H]2C1)[C@@H](C(=O)[O-])OC3</smiles><smiles>CC1(C)C[C@@H]2C3=C(COC3=O)C[C@@H](C1)C2C#N</smiles>

The deethoxycarbonylation of 409 with HMPA, $\mathrm{LiCl}\left(160^{\circ} \mathrm{C}, 3 \mathrm{~h}\right)$ yielded $410(85 \%) .{ }^{217}$
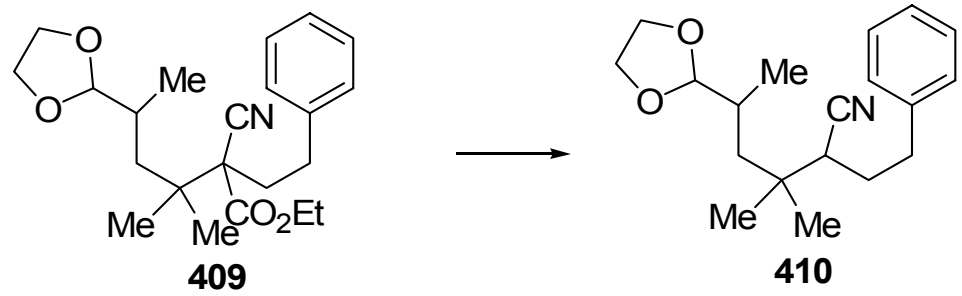

Treatment of 411 with $\mathrm{DMF}$ and $\mathrm{CaCl}_{2}$ dihydrate $\left(160^{\circ} \mathrm{C}, 2.5 \mathrm{~h}\right)$ led to mixture of exo/endo (1:1) epimers $412(79 \%)$ which were used in a route leading to an azadicarbaprostaglandin. ${ }^{218}$

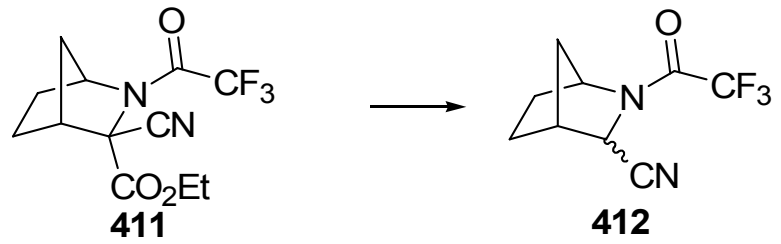


The deethoxycarbonylation of $\mathbf{4 1 3}$ (or the corresponding methyl ester) with DMSO, LiCl and $\mathrm{H}_{2} \mathrm{O}\left(173^{\circ} \mathrm{C}, 4 \mathrm{~h}\right)$ led to $414(78 \%){ }^{219}$<smiles>CCOC(C)(C)C1(C#N)CC2(CC(c3ccccc3)C1(C)OCC)OCCO2</smiles><smiles>CN(C)C1C(c2ccccc2)CC2(CC1c1ccccc1)OCCO2</smiles>

The demethoxycarbonylation of methyl ester 415 ( or the corresponding ethyl ester) with DMSO, $\mathrm{LiCl}$ and $\mathrm{NaHCO}_{3}\left(165^{\circ} \mathrm{C}, 3 \mathrm{~h}\right)$ led to $1: 1$ mixture of the $E$ - and $Z$-stereoisomeric nitriles $416(75 \%)$, along with benzaldehyde $(18 \%){ }^{220}$

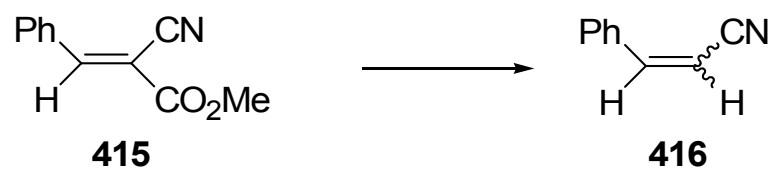

\subsection{Sulfones}

\subsubsection{From $\alpha$-sulfonyl esters}

Treatment of sulfone $\mathbf{4 1 7}$ with DMSO, $\mathrm{NaCl}$ and water (reflux, 8h) led to the decarbomethoxylated product $418(63 \%){ }^{221}$

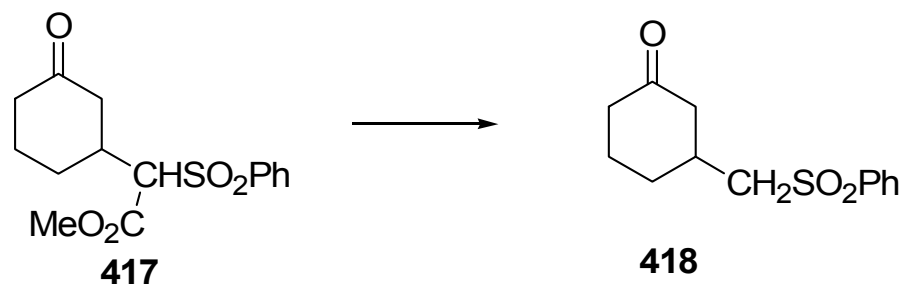

The 1,6- $\alpha$-tolylsulfonyl ester 419 on treatment with DMSO and $\mathrm{NaCl}\left(170^{\circ} \mathrm{C}, 18 \mathrm{~h}\right)$ led to decarbomethoxylation product $420(99 \%){ }^{222}$
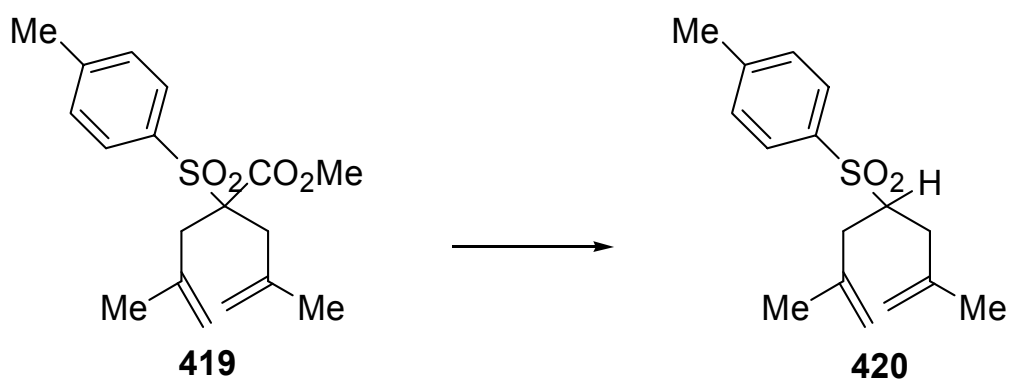
The $\alpha$-carbomethoxy sulfone $\mathbf{4 2 1}$ on heating in DMSO, $\mathrm{NaCl}$ and water $\left(160^{\circ} \mathrm{C}, 6 \mathrm{~h}\right)$ led to sulfone $422(86 \%){ }^{223}$

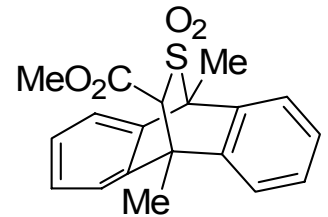

421

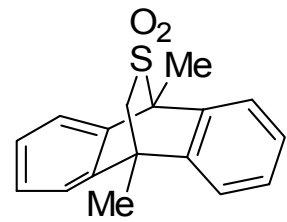

422

Without providing any experimental details, the demethoxycarbonylation of $\mathbf{4 2 3}$ was reported to afford a good yield of non-racemic 424, an intermediate to be used in the synthesis of additional chiral analogues. ${ }^{224}$

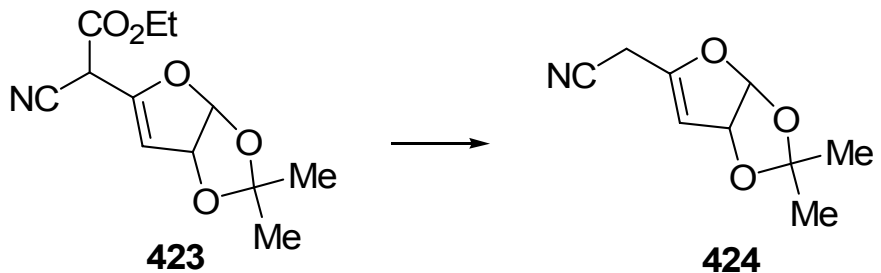

\subsection{Sulfoximines}

\subsubsection{From $\alpha$-carbomethoxy sulfoximines}

The demethoxycarbonylations of both enantiomers of 425 using DMSO and $\mathrm{NaCN}\left(120^{\circ} \mathrm{C}\right)$ led to the corresponding sulfoximine enantiomers $426 .^{225}$

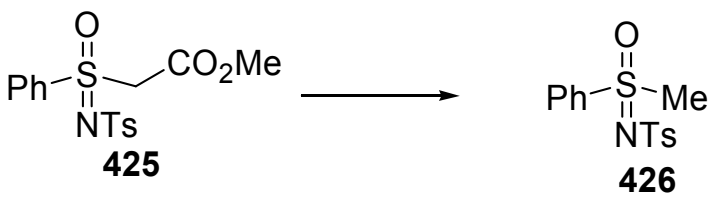

The diastereoisomeric chiral mixture of 427 on treatment with $\mathrm{DMSO}, \mathrm{NaCN}\left(80^{\circ} \mathrm{C}, 48 \mathrm{~h}\right)$ led to optically active $\mathbf{4 2 8}(80 \%)$ as a diastereoisomeric mixture. ${ }^{225}$

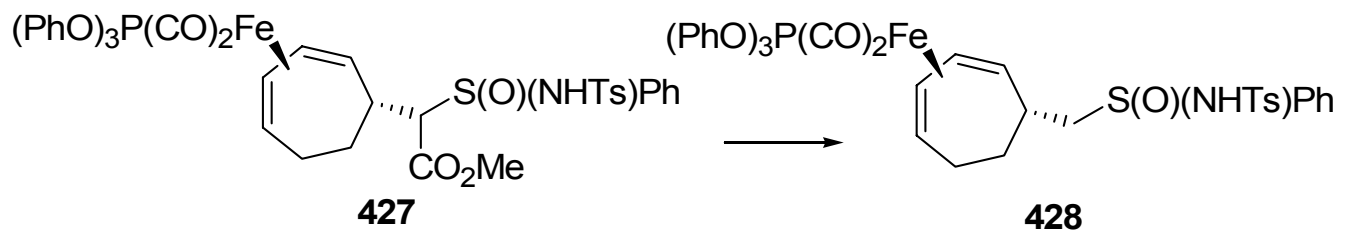




\subsection{Chiral phosphine oxides}

\subsubsection{From P-chiral phosphinyl acetates}

One illustrative example of the preparation of chiral phosphine oxides involves the treatment of $(+)-(R) 429$ with DMSO, $\mathrm{LiCl}$ which led to $(-)-(S) \mathbf{4 3 0}(34 \%$ yield $){ }^{226 a, b}$

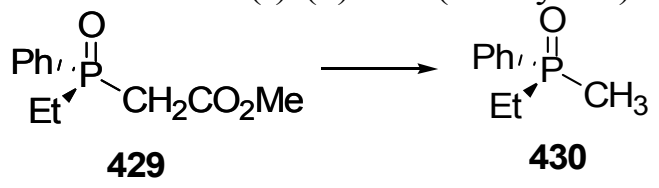

Treatment of $\alpha$-substituted (-)-( $\left.\mathrm{S}_{\mathrm{P}}\right)$-ethyl((menthoxycarbonyl)methyl)phenylphosphine oxides 431 with $\mathrm{LiCl}$ in aqueous DMSO (reflux, 8-18 h) led to the corresponding (-)- $\mathrm{R}_{\mathrm{p}}$ alkylethylphosphineoxides 432 in $54-70 \%$ yields in 100\% enantiomeric purity. ${ }^{227}$

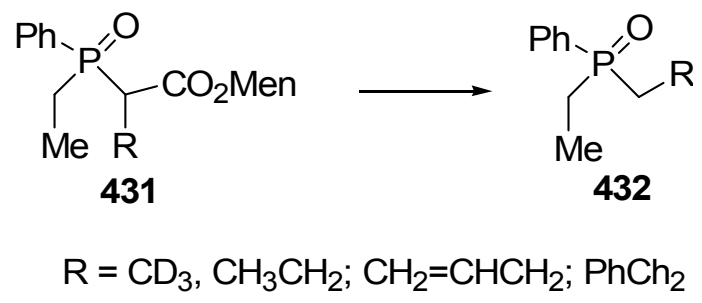

\subsection{Ketophosphonates}

\subsubsection{From 2-acylphosphonoacetates}

It has been reported that 2-acylphosphonoacetates such as $\mathbf{4 3 3}$ undergo deethoxy-carbonylations with water (oil bath, $120-140^{\circ} \mathrm{C}, 2-3 \mathrm{~h}$ ) to afford $\beta$-ketophosphonates such as 434 (70\%). A number of other substrates were also evaluated. ${ }^{228}$

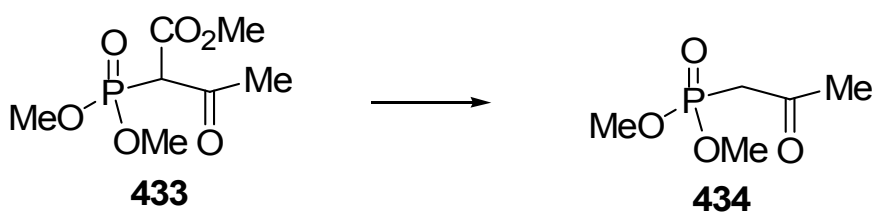

\subsection{Nitro analogues}

\subsubsection{From $\alpha$-nitro esters}

Only one example of a dealkoxycarbonylation of an $\alpha$-nitro ester could be found.

Treatment of $\alpha$-nitro ester 435 with $\mathrm{DMSO}, \mathrm{NaCl}$ and water $\left(150^{\circ} \mathrm{C}, 4 \mathrm{~h}\right)$ led to deethoxycarbonylation to afford nitro derivative $436(66 \%){ }^{229}$<smiles>CCOC(=O)C(C1C=CC([C@H]2C=CC(n3ccc4c(Cl)nc(N)nc43)C2)C1)[C@H]1C=C[C@@H](C[N+](=O)[O-])C1</smiles> 


\subsection{2-Cyclohexenone derivatives}

\subsubsection{From 4-carbalkoxy-2-cyclohexanones}

The chemoselective deethoxycarbonylation of the keto diester 437 on treatment with DMSO, $\mathrm{LiCl}$ and water $\left(180-190^{\circ} \mathrm{C}, 5 \mathrm{~h}\right)$ led to $438(70 \%){ }^{230}$<smiles>CCOC(=O)CC1=C(C)C(C(=O)OCC)CCC1=O</smiles>

437<smiles>CCOC(=O)CC1=C(C)CCCC1=O</smiles>

438

Upon heating 439 in DMSO, $\mathrm{NaCl}$ and water $\left(140^{\circ} \mathrm{C}, 10 \mathrm{~h}\right.$, sealed tube), 440 (19\%) was obtained, the product of a demethoxycarbonylation and a demethoxylation. This yield (40\%) was improved with the use of $\mathrm{MgCl}_{2}$. The mesylate (OMs instead of $\mathrm{OMe}$ in 439, $\alpha$-position to the ester group) under the $\mathrm{MgCl}_{2}$-DMSO conditions led to 440 (89\%). This intermediate was used in a synthesis of Erythrina and related alkaloids. ${ }^{231}$<smiles></smiles>

439<smiles>COc1cc2c(cc1OC)C1(CCCC1)C(CC=O)=CC(=O)N2C</smiles>

440

\subsection{Heterocyclic vinylogous dethoxycarbonylation}

The deethoxycarbonylation of the heterocyclic susbstrate 441 to afford 442 (32\%) was accomplished by treatment with $\mathrm{DMSO}, \mathrm{NaCl}$ and water $\left(145^{\circ} \mathrm{C}, 6 \mathrm{~h}\right){ }^{232}$
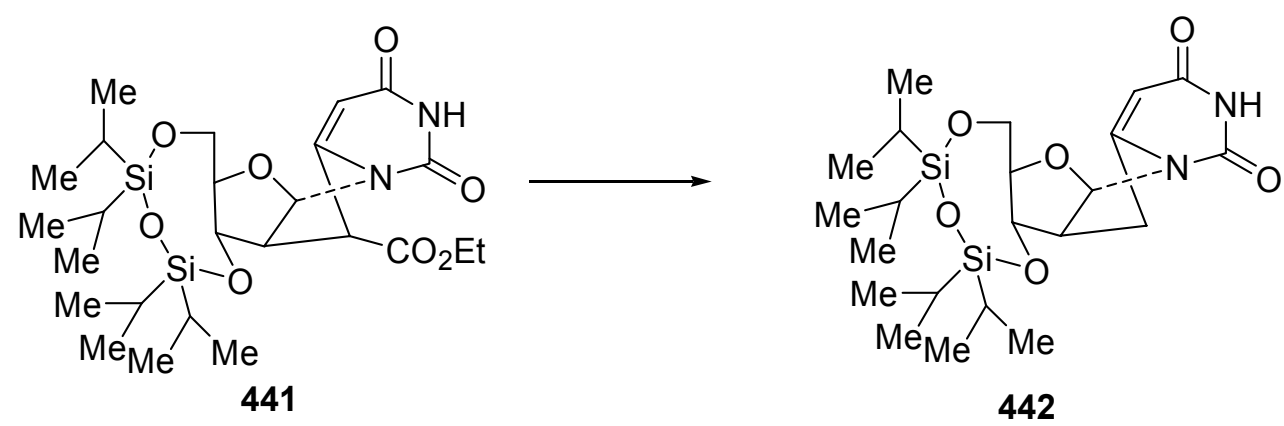

\subsection{Tetra-demethoxycarbonylation}


Treatment of 443 with $\mathrm{DMSO}, \mathrm{NaCl}$ and water $\left(140^{\circ} \mathrm{C}, 4 \mathrm{~h}\right)$ led to 444 (quantitatively). A rational mechanism is proposed. ${ }^{233}$

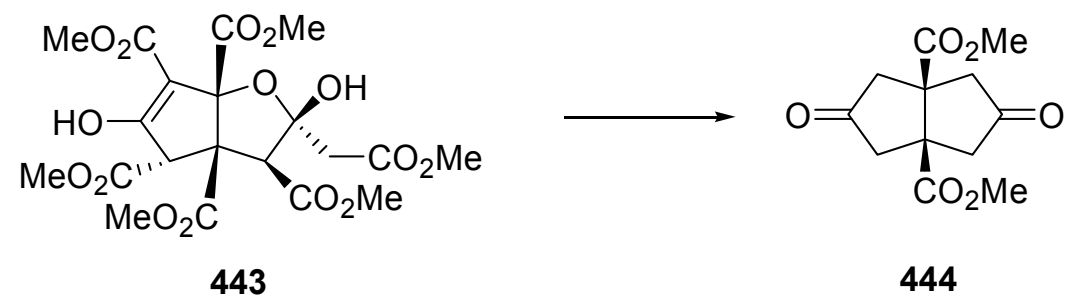

\section{Conclusions}

Dealkoxycarbonylations of a wide variety of substrates have been accomplished using $\mathrm{NaCN}$, $\mathrm{NaCl}$ or $\mathrm{LiCl}$ and water in dipolar aprotic solvents such as DMSO and DMF. This procedure will continue to be useful in the dealkoxycarbonylations of activated ester functionalities.

\section{References}

1. Krapcho, A. P. Synthesis 1982, 893.

2. Backvall, J-E.; Vagberg, J-O.; Granberg, K. L. Tetrahedron Lett. 1989, 30, 617.

3. Ito, S.; Saito, N.; Hatekeda, K.; Goto, T.; Ikushima, Y.; Asano, T. Bull. Chem. Soc. Jpn. 1984, 57, 2015.

4. Curran, D. P.; Zhang, Q. Adv. Synth. Catal. 2003, 345, 329.

5. Kolasa, A. J. Fluorine Chem. 1987, 36, 29.

6. Toro, A.; Nowak, P.; Deslongchamps, P. J. Am. Chem. Soc. 2000, 122, 4526.

7. Bram, G.; Cabaret, D.; Welvart, Z.; Geraghty, N. W. A.; Garvey, J. Tetrahedron Lett. 1988, 29, 4615.

8. Dolle, R. E.; Osifo, K. I. Li, C.-S. Tetrahedron Lett. 1991, 32, 5029.

9. Langlois, M.; Yang, D.; Soulier, J.-L.; Florac, C. Synth. Commun. 1992, 22, 3115.

10. Lastdrager, B.; Timmer, M. S. M.; van der Marel, G. A.; Overkleeft, H. S. Tetrahedron Lett. 2005, 46, 6195.

11. Austad, B. C.; Hart, A. C.; Burke, S. D. Tetrahedron 2002, 58, 2011.

12. Hok, S.; Schore, N. E. J. Org. Chem. 2006, 71, 1736.

13. Pellissier, H.; Santelli, M. Tetrahedron 1996, 52, 9093.

14. Gonzalez, G. I.; Zhu, J. J. Org. Chem. 1999, 64, 914.

15. Back, T. G.; Wulff, J. E. Angew. Chem. Int. Ed. 2004, 43, 6493.

16. Murali, D.; Rao, G. S. Krishna, Indian J. Chem. 1987, 26B, 158.

17. Morgan, T. K,.Jr.; Lis, R.; Marisca, A. J.; Argentieri, T. M.; Sullivan, M. E.; Wong, S. S. J. Med. Chem. 1987, 30, 2259. 
18. Gibson, K. R.; Hitzel, L.; Mortishire-Smith, J.; Gerhard, U.; Jelley, R. A.; Reeve, A. J.;

Rowley, M.; Nadin, A.; Owens, A. P. J. Org. Chem. 2002, 67, 9354.

19. Narukawa, Y.; Nishi, K.; Onoue, H. Tetrahedron 1997, 53, 539.

20. Dhavale, D. D.; Saha, N. N.; Desai, V. N. J. Org. Chem. 1997, 62, 7482.

21. Saengchantara, S. T.; Wallace, T. W. Tetrahedron 1990, 46, 3029.

22. Oshima, E.; Kumazawa, T.; Obase, H. Chem. Pharm. Bull. 1993, 41, 36.

23. Heathcock, C. H.; Stafford, J. A. J. Org. Chem. 1992, 57, 2566.

24. Atkins, E. F.; Dabbs, S.; Guy, R. G.; Mahomed, A. A.; Mountford, P. Tetrahedron 1994, 50, 7253.

25. (a)Aubert, C.; Begue, J.-P. Charpentier-Morize, M.; Nee, G.; Langlois, B. J. Fluorine Chem. 1989, 44, 377. (b) Begue, J.-P.; Bonnet-Delpon, D. Tetrahedron 1991, 47, 3207.

26. Bogolyubskii, A. V.; Il'chenko, A. Ya.; Yagupol'skii, L. M. J. Org. Chem. USSR (Engl. Transl) 1987, 23, 2027.

27. Cooper, K.; Pattenden, G. J. Chem. Soc. Perkin Trans. 1 1984, 799.

28. Daniewski, A. R.; Warchol, T. Polish J. Chem. 1992, 66, 1985.

29. Okano, K.; Suemune, H.; Sakai, K. Chem. Pharm. Bull. 1988, 36, 1379.

30. Taber, D. F.; Raman, K.; Gaul, M. D. J. Org. Chem. 1987, 52, 28.

31. Islam, Md. S.; Kawanao, T.; Hatanaka, M.; Ueda, I. Tetrahedron Lett. 1996, 37, 5735.

32. Fleming, I.; Ghosh, S. K. J. Chem. Soc. Perkin Trans. 1, 1998, 2711.

33. Baier, H.; Durner, G.; Quinkert, G. Helv. Chim. Acta 1985, 68, 1054.

34. Knolker, H. J.; Winterfeld, E. Liebigs Ann. Chem. 1986, 465.

35. Crimmins, M. T.; Mascarella, S. W. J. Am. Chem. Soc. 1986, 108, 3435.

36. Sonawane, H. R.; Naik, V. G.; Bellur, N. S.; Shah, V. G.; Purohit, P. C.; Kumar, M. U.; Kulkarni, D. G.; Ahuja, J. R. Tetrahedron 1991, 47, 8259.

37. Camps, P.; Figueredo, M. Can. J. Chem. 1984, 62, 1184.

38. (a)Yates, P.; Grewal, R. S.; Hayes, P. C.; Sawyer, J. F. Can. J. Chem. 1988, 66, 2805. (b) Yates, P.; Stevens, K. E. Tetrahedron 1981, 37, 4401. (c) Yates, P.; Stevens, K. E. Can. J. Chem. 1982, 60, 825.

39. Barrett, A. G. M.; Boys, M. L.; Boehm, T. L. J. Org. Chem. 1996, 61, 685.

40. Paquette, L. A.; Wang, H.-L. J. Org. Chem. 1996, 61, 5352.

41. Taber, D. F.; Jiang, Q.; Chen, B.; Zhang, W.; Campbell, C. L. J. Org. Chem. 2002, 67, 4821.

42. Brooks, D. W.; Bevinakatti, H. S.; Kennedy, E.; Hatthaway, J. J. Org. Chem. 1985, 50, 628.

43. Ibuka, T.; Minakata, H.; Mitsui, Y.; Hayashi, K.; Taga, T.; Inubushi, Y. Chem. Pharm. Bull, 1982, 30, 2840.

44. Maiti, B. C.; Lahiri, S. Tetrahedron 1998, 54, 9111.

45. Selvakumar, N.; Subba Rao, G. S. R. J. Chem. Soc. Perkin Trans. 1 1994, 3217.

46. Subba Rao, G. S. R.; Hariprakasha, H. K.; Girija, A, T.; Bhaskar, K. V. J. Indian Chem. Soc. 1997, 74, 961.

47. Smith, A. B., III; Kingery-Wood, J.; Leenay, T. L.; Nolen, E. G.; Sunazuka, T. J. Am. Chem Soc. 1992, 114, 1438. 
48. Suto, M. J.; Tramposch, K. M.; Wierzba, M.; Solo, A. J.; Duax, W. J. Org. Chem. 1987, 52, 2263.

49. Stille, J. R.; Grubbs, R. H. J. Am. Chem. Soc. 1986, 108, 855.

50. Ihara, M.; Makita, K.; Takasu, K. J. Org. Chem. 1999, 64, 1259

51. Zhang, Q.; Mohan, R. M.; Cook, L.; Kazanis, S.; Peisach, D.; Foxman, B. M.; Snider, B. B. J. Org. Chem.. 1993, 58, 7640.

52. Evans, D. A.; Scheidt, K. A.; Downey, C. W. Org. Lett. 2001, 3, 3009.

53. Lu, Y.; Barth, G.; Kieslich, K.; Strong, P. D.; Duax, W. L.; Djerassi, C. J. J. Org. Chem. 1983, 48, 4549.

54. Posner, G. H.; Shulman-Roskes, E. M. Tetrahedron 1992, 48, 4677.

55. Kido, F.; Akibo, T.; Kato, M. J. Chem. Soc. Perkin Trans. 1 1992, 229.

56. Duhamel, P.; Kotera, M. J. Org. Chem. 1982, 47, 1688.

57. Kutney, J. P.; Chen, Y.-H.; Rettig, S. J. Can. J. Chem. 1996, 74, 666.

58. Aristoff, P. A.; Johnson, P. D.; Harrison, A. W. J. Am. Chem. Soc. 1985, 107, 7967.

59. Hirai, Y.; Hagiwara, A.; Terada, T.; Yamazaki, T. Chem. Lett. 1987, 2417.

60. Ohuchida, S.; Hamanaka, N.; Hayashi, M. Tetrahedron 1983, 39, 4269.

61. Paquette, L. A.; Friedrich, D.; Pinard, E.; Williams, J. P.; St. Laurent, D.; Roden, B. A. J. Am. Chem. Soc. 1993, 115, 4377.

62. Ahmad, Z.; Goswami, P.; Venkateswaran, R. V. Tetrahedron 1989, 45, 6833.

63. Honda, T.; Ishige, H.; Nagase, H. J. Chem. Soc. Perkin Trans. 1 1994, 3305.

64. Bradbury, R. H.; Gilchrist, T. L.; Rees, C. W. J. Chem. Soc. Perkin Trans.1 1981, 3225.

65. White, J. D.; Somers, T. C.; Yager, K. M. Tetrahedron Lett. 1990, 31, 59.

66. (a) Baraldi, P. G.; Barco, A.; Benetti, S.; Pollini, G. P.; Polo, E.; Simoni, D. J. Org. Chem. 1985, 50, 23. (b) Baraldi, P. G.; Barco, A.; Benetti, S.; Pollini, G. P.; Simoni, D.

Tetrahedron Lett. 1983, 24, 5669.

67. Marchand, A. P.; Chong, H.-S.; Shukla, R.; Sharma, G. V. M.; Kumar, K. A.; Zope, U. R.; Bott, S. G. Tetrahedron 1996, 52, 13531.

68. Marchand. A. P.; Rajapaksa, D.; Reddy, S. P. Watson, W. H.; Nagl, A. J. Org. Chem. 1989, $54,5086$.

69. Terunuma, D.; Motegi, M.; Tsuda, M.; Sawada, T.; Nozawa, H.; Nohira, H. J. Org. Chem. 1987, 52, 1630 .

70. Furstner, A.; Krause, H. J. Org. Chem. 1999, 64, 8281.

71. Schreiber, S. L.; Kelley, S. E.; Porco, J. A., Jr.; Sammakia, T.; Suh, E. M. J. Am.. Chem. Soc. 1988, 110, 6210.

72. Strekowski, L.; Visnick, M.; Battiste, M. A. J. Org. Chem. 1986, 51, 4836.

73. Augustyns, B.; Maulide, N.; Marko, I. E. Tetrahedron Lett. 2005, 46, 3895

74. Eliel, E. L.; Bax, X.; Ohwa, M. J. Chin. Chem. Soc. 2000, 47, 63.

75. Villhauer, E. B.; Anderson, R. C. J. Org. Chem. 1987, 52, 1186.

76. Ando, M.; Kataoka, N.; Yasunami, M.; Takase, K.; Hirata, N.; Yanagi, Y. J. Org. Chem. 1987, 52, 1429. 
77. Manhas, M. S.; Bhawal, B. M.; Shankar, B. B.; Bose, A. K. J. Indian Chem. Soc. 1985, 62, 891.

78. Wee, A. G. H.; Liu, B.; McLeod, D. D. J. Org. Chem. 1998, 63, 4218.

79. Schroeder, M. C.; Kiely, J. S.; Laborde, E.; Johnson, D. R.; Szotek, D. L.; Domagala, J. M.; Stickney, T. M.; Michel, A.; Kampf, J. W. J. Heterocyclic Chem. 1992, 29, 1481.

80. Wee, A. G. H.; Duncan, S. C.; Fan G.-J. Tetrahedron: Asymmetry 2006, 17, 297.

81. Giles, M.; Hadley, M. S.; Gallagher, T. J. Chem. Soc. Chem. Commun. 1990, 1047.

82. Anada, M.; Mita, O.; Watanabe, H.; Kitagaki, S.; Hashimoto, S. Synlett 1999, 1775.

83. Bosch, J.;Bonjoch, J.; Serret, I. J. Heterocyclic Chem. 1982, 19, 489.

84. Cirillo, P. F.; Panek, J. S. J. Org. Chem. 1994, 59, 3055.

85. Jeffery, S. M.; Sutherland, A. G.; Pyke, S. M.; Powell, A. K.; Taylor, R. J. K. J. Chem Soc. Perkin Trans. 1 1993, 2317.

86. Lemaire, S.; Giambastiani, G,; Prestat, G.; Polli, G. Eur. J. Org. Chem. 2004, 2840.

87. Rabiczko. J.; Urbanczyk-Lipkowska, Z.; Chmielewski, M. Tetrahedron 2002, 58, 1433.

88. Bosch, J.; Bonjoch, J. J. Org. Chem. 1981, 46, 1538.

89. Takeuchi, Y.; Kamada, Y.; Nishimura, K.; Nishioka, H.; Nishikawa, M.; Hashigaki, K.;

Yamato, M.; Harayama, T. Chem. Pharm. Bull. 1994, 42, 796.

90. Bailey, P. D.; McLay, N. R. J. Chem. Soc. Perkin Trans. 1 1993, 441.

91. Stoit, A. R.; Pandit, U. K. Tetrahedron 1989, 45, 849.

92. Overman, L. E.; Robichaud, A. J. J. Am. Chem. Soc. 1989, 111, 300.

93. Feldman, P. L.; Rapoport, H. J. Am. Chem. Soc. 1987, 109, 1603.

94. Molander, G. A; Haas, J.; Tetrahedron 1999, 55, 617.

95. Molander, G. A.; Czako, B.; St. Jean, D. J.. J. Am. Chem. Soc. 2006, 71, 1172.

96. Takahashi, T.; Kotsubo, H.; Koizumi, T. J. Chem. Soc. Perkin Trans. 1 1991, 1667.

97. Kunick, C. Arch. Pharm. (Weinheim) 1991, 324, 579.

98. Jeanneau-Nicolle, E.; Benoit-Guyod, M.; Leclerc, G. Synth. Commun. 1991, 21, 1443.

99. Collins, I.; Castro, J. L. Tetrahedron Lett. 1999, 40, 4069.

100.Molander, G. A.; Siedem, C. S. J. Org. Chem. 1995, 60, 130.

101.Ishmuratov, G. Yu.; Kakovleva, M. P.; Galyautinova, A. V.; Muslukhov, R. R.; Tolstikov, G. A. Russ. Chem. Bull. Int. Edit. 2003, 52, 74.

102. Artal, C.; Ros, M. B.; Serrano, J. L.; Pereda, N.; Etxebarria, J.; Folcia, C. L.; Ortega, J. Macromolecules 2001, 34, 4244.

103.Dickschat, J. S.; Wenzel, S. C.; Bode, H. B.; Muller, R.; Schulz, S. ChemBioChem 2004, 5, 778.

104. Tokuda, M.; Fujita, H.; Nitta, M.; Suginome, H. Heterocycles 1996, 42, 385.

105.Nishikimi, Y.; Iimori, T.; Sodeoka, M.; Shibasaki, M. J. Org. Chem. 1989, 54, 3354.

106. Tamura, R.; Sato, M.; Oda, D. J. Org. Chem. 1986, 51, 4368.

107.Holmes, A. B.; Swithenbank, C.; Williams, S. F. J. Chem. Soc. Chem. Commun. 1986, 265.

108.Drew, M. G. B.; Mann, J.; Alison, T. J. Chem. Soc. Perkin Trans. 1 1986, 2279. 
109. Yamazaki, T.; Matoba, K.; Itooka, T.; Chintani, M.; Momose, T.; Muraoka, O. Chem. Pharm. Bull. 1987, 35, 3453.

110.Solladie, G.; Boeffel, D.; Maignam, J. Tetrahedron, 1995, 51, 9559.

111.Domon, K.; Mori, K. Eur. J. Org. Chem. 1999, 979.

112.Schied, G.; Kuit, W.; Ruijter, E.; Orru, R. V. A.; Henke, E.; Bornscheuer, U.; Wessjohann, L. A. Eur. J. Org. Chem. 2004, 1063.

113.Yu, Y.; Chen, G.-Q.; Zhu, J.; Zhang, X.-S.; Chen, S.-X.; Tang, H.-T.; Zhang, P. J. Chem. Soc. Perkin Trans. 1 1990, 2239.

114.Broka, C. A.; Eng, K. K. J. Org. Chem. 1986, 51, 5043.

115.Dombrovskii, V. A.; Fonskii, D. Yu.; Filippova, T. M.; Mironov, V. A. J. Org. Chem. USSR (Engl. Transl) 1986, 22, 1471.

116.Hudlicky, T.; Short, R. P. J. Org. Chem. 1982, 47, 1522.

117. White, W. L.; Anzeveno, P. B.; Johnson, F. J. Org. Chem. 1982, 47, 2379.

118.Greene, A. E.; Teixeira, M. A.; Barreiro, E. Cruz, A.; Crabbe, P. J. Org. Chem. 1982, 47, 2553.

119.Tolstikov, G. A.; Miftakhov, M. S.; Valeev, F. A. J. Org. Chem. USSR (Engl. Transl) 1984, $20,1522$.

120.Lee, W. Y.; Jang, S. Y.; Kim, M.; Park, O. S. Synth. Commun. 1992, 22, 1283.

121.Ho, T.-L.; Liu, S.-H. Synth. Commun. 1982, 12, 501.

122.He, M.; Tanimori, S.; Ohira, S.; Nakayama, M. Tetrahedron 1997, 53, 13307.

123.Cossy, J.; Bouzbouz, S.; Hakiki, A. Tetrahedron 1999, 55, 11289.

124.Bohlmann, F.; Wegner, P.; Jakupovic, J.; King, R. M. Tetrahedron 1984, 40, 2537.

125.Weyerstahl, P.; Brendel, J.; Liebigs Ann. Chem. 1992, 669.

126.(a) Tremblay, M. R.; Auger, S.; Poirier, D. Bioorg. Med. Chem. 1995, 3, 505. (b) Tremblay, M. R.; Auger, S.; Poirier, D. Synth. Commun. 1995, 25, 2483.

127.Carling, R. W.; Clark, J. S.; Holmes, A. B. J. Chem. Soc. Perkin Trans. 1 1992, 83.

128. Garratt, P. J.; Porter, J. R. J. Org. Chem. 1986, 51, 5450.

129.(a) Barnier, J. P.; Loupy, A.; Pigeon, P.; Ramdani, M.; Jacquault, P. J. Chem. Soc. Perktin

Trans. 1, 1993, 397. (b) Loupy, A.; Petit, A.; Hamelin, J.; Texier-Boullet, F.; Jacquault, P.;

Mahe, D. Synthesis 1998, 1213. (c) Perreux, L.; Loupy, A. Tetrahedron 2001, 57, 9199.

130.Spreitzer, H.; Piringer, I.; Pichler, A.; Holzer, W.; Schreder, P.; Widhalm, M. Chirality

1999, 11, 14.

131.Hagiwara, H.; Uda, H. J. Chem. Soc. Chem. Commun. 1988, 815.

132.Higiwara, H.; Uda, H. J. Chem. Soc. Chem. Commun. 1987, 1351.

133. Tamai, Y.; Hagiwara, H.; Uda, H. J. Chem. Soc. Perkin Trans. 1 1986, 1311.

134.Strunz, G. M.; Bethel, R.; Dumas, M. T.; Boyonoski, N. Can. J. Chem. 1997, 75, 742.

135.Kato, T.; Hirukawa, T.; Uyehara, T.; Yamamoto, Y. Tetrahedron Lett. 1987, 28, 1439.

136.Tochtermann, W.; Panitzsch, T.; Habeck, T.; Wolff, C.; Peters, E.-M.; Peters, K.; von

Schnering, H. G. Tetrahedron 1999, 55, 1027.

137.Furstner, A.; Radkowski, K. Peters, H. Angew. Chem.. Int. Ed. 2005, 44, 2777. 
138.Wee, A, G. H.; Yu, Q. J. Org. Chem. 1997, 62, 3324.

139.(a) Wee, A. G. H.; Yu, Q.J. Org. Chem. 2001, 66, 8935. (b) Wee, A, G. H.; Yu, Q.

Tetrahedron Lett. 2000, 41, 587.

140.Lamarque, L.; Meou, A.; Brun, P. Tetrahedron 1998, 54, 6497.

141.Nylund, C. S.; Smith, D. T.; Klopp, J. M.; Weinreb, S. M. Tetrahedron 1995, 51, 9301.

142.Leeper, F. J.; Rock, M. J. Fluorine Chem. 1991, 51, 381.

143.Orduna, A.; Zepeda, L. G.; Tamariz, J. Synthesis 1993, 375.

144.Fronza, G.; Fuganti, C.; Grasselli, P.; Pedrocchi-Fantoni, G.; Servi, S. Tetrahedron Lett. 1992, 33, 5625.

145.Gilbert, J. C; Pinto, M. J. Org. Chem. 1992, 57, 5271.

146.Hedenstrom. E.; Hogberg, H.-E.; Wassgren, A.-B.; Bergstrom, G.; Lofqvist, J.; Hanson, B.;

Anderbrant, O. Tetrahedron 1992, 48, 3139.

147.Jahn, U.; Hartmann, P.; Dix, I.; Jones, P. G. Eur. J. Org. Chem. 2001, 3333.

148.Lamarque, L.; Meou, A.; Brun, P. Can. J. Chem. 2000, 78, 128.

149. Toyota, M.; Nishikawa, Y.; Fukumoto, K. Heterocycles 1998, 47, 675.

150.(a) Kido, F.; Sinha, S. C.; Abiko, T.; Watanabe, M.; Yoshikoshi, A. J. Chem. Soc. Chem.

Commun. 1990, 418. (b) Kido, F.; Sinha, S. C.; Abiko, T.; Watanabe, M.; Yoshikoshi, A

Tetrahedron 1990, 46, 4887.

151.Abele, W.; Schmidt, R. R. Tetrahedron Lett. 1981, 22, 4807.

152.Michellys, P.-Y.; Pellissier, H.; Santelli, M. Tetrahedron Lett. 1993, 34, 1931.

153. Maurin, P.; Ibrahim-Ouli, M.; Santelli, M. Eur. J. Org. Chem. 2002, 151.

154. Maurin, P.; Ibrahim-Ouali, M.; Santelli, M. Tetrahedron Lett. 2001, 42, 847.

155.Oumzil, K.; Ibrahim-Ouali, M.; Santelli, M. Synlett 2005, 1695.

156. Kasturi, T. R.; Jois, H. R. Y.; Indian J. Chem. 1990, 29B, 615.

157.Sanz-Cervera, J. F.; Williams, R. M.; Marco, J. A.; Lopez-Sanchez, J. M.; Gonzalez, F.;

Martinez, M. E.; Sancenon, F. Tetrahedron 2000, 56, 6345.

158. Stewart A.O.; Bhatia, P. A.; McCarty, C. M.; Patel, M. V.; Staeger, M. A.; Arendsen, D. L.;

Gunawardana, I. W.; Melcher, L. M.; Zhu, G.-D.; Boyd, S. A.; Fry, D. G.; Cool, B. L.;

Kifle, L.; Lartey, K.; Marsh, K. C.; Kempf-Grote, A. J.; Kilgannon, P.; Wisdom, W.; Meyer,

J.; Gallatin, W. M.; Okasinski, G. F. J. Med. Chem. 2001, 44, 988.

159.Kametani, T.; Kanaya, N.; Ihara, M. J. Chem. Soc. Perkin Trans. 1 1981, 950.

160. Tsuda, Y.; Sakai, Y. Synthesis 1981, 119.

161.(a) Tsuda, Y.; Murata, M. Tetrahedron Lett. 1986, 27, 3385. (b) Tsuda, Y.; Sakai, Y.; Nakai, A.; Ohshima, T.; Hosoi, S.; Isobe, K.; Sano, T.; Chem. Pharm. Bull. Jpn. 1990, 38, 1462

162.Chavan, S. P.; Kale, R. R.; Pasupathy, K. Synlett 2005, 1129.

163.Matsuyama, H.; Miyazawa, Y.; Takei, Y.; Kobayashi, M. J. Org. Chem. 1987, 52, 1703.

164.Casy, G.; Lane, S.; Taylor, R. J. K. J. Chem. Soc. Perkin Trans. 1 1986, 1397.

165.Floyd, D. M.; Moquin, R. V.; Atwal, K. S.; Ahmed, S. Z.; Spergel, S. H.; Gougoutas, J. Z.;

Malley, M. F. J. Org. Chem. 1990, 55, 5572.

166.Bohrer, G.; Bohrer, P. Knorr, Chem. Ber. 1990, 123, 2167. 
167.Harmata, M.; Gamlath, C. B.; Barnes, C. L.; Jones, D. E. J. Org. Chem. 1995, 69, 5077.

168.Sworen, J. C.; Smith, J. A.; Berg, J. M.; Wagener, K. B. J. Am. Chem. Soc. 2004, 126, 11238.

169.Schafer, H.-J.; Baringhaus, K.-H. Liebigs Ann. Chem. 1990, 351.

170.(a) Duval, O.; Rguigue, A.; Gomes, L. M. Heterocycles 1994, 38, 2709. (b) Duval, O.;

Gomes, L. M. Tetrahedron 1989, 45, 4471.

171.Kruckert, K.; Flashbarth, B.; Schulz, S.; Hentschel, U.; Weldon, P. J. J. Nat. Prod. 2006, 69, 863.

172.Schulz, S.; Arsene, C.; Tauber, M.; McNeil, J. N. Phytochemictry 2000, 54, 325.

173.Irie, H.; Mizuno, Y.; Taga, T.; Osaki, K. K. J. Chem. Soc. Perkin Trans. 1 1982, 25.

174.Bianchi, G.; Grugni, M. Gazz. Chim. Ital. 1985, 115, 633.

175.Stritzke, K.; Schulz, S.; Nishida, R. Eur. J. Org. Chem. 2002, 3884.

176.Venkateswarlu, S.; Ramachandra, M. S.; Rambabu, M.; Subbaraju, G. V. J. Asian Nat.

Prod. Rep. 2000, 2, 111.

177.Jondiko, I. J. O.; Pattenden, G. J. Chem. Soc. Perkin Trans. 1 1983, 467.

178.Heinicke, G. W. ; Morella, A. M.; Orban, J.; Prager, R. H.; Ward, A. D. Aust. J. Chem. 1985, 38, 1847.

179. Moorthy, B. K.; Miller, D. D. Indian J. Chem. 1990, 29B, 1084.

180. Smith, J. O.; Mandal, B. K.; Filler, R.; Beery, J. W. J. Fluorine Chem. 1997, 81, 123.

181.Smith, J. O.; Mandal B. K.; J. Heterocyclic Chem. 1997, 34, 1441.

182.Hagiwara, H.; Katsumi, T.; Kamat, V. P.; Hoshi, T.; Suzuki, T.; Ando, M.. J. Org. Chem. 2000, 65, 7531.

183.Nystrom, J.-E.; Backvall, J.-E. J. Org. Chem. 1983, 48, 3947.

184.Hattori, K.; Grossman, R. B. J. Org. Chem. 2003 68, 1409.

185.Iyer, P.; Ghosh, S. K. Tetrahedron Lett. 2002, 43, 9437.

186. Sanchez, I. H.; Ortega, A.; Garcia, G.; Larraza, M. I.; Flores, H. J.; Synth. Commun. 1985, $15,141$.

187.Sucrow, W.; Radecker, G. Chem. Ber. 1988, 121, 219.

188. Taylor, M. S.; Zalatn, D. N.; Lerchner, A. M.; Jacobsen, E. N. J. Am. Chem. Soc. 2005, 127, 1313.

189.Amat, M.; Basas, O.; Canto, M.; Llor, N.; Santos, M. M. M.: Bosch, J. Tetrahedron 2005, $61,7693$.

190.Wessig, P.; Muhling, O. Helv. Chim. Acta 2003, 86, 865.

191.Bhattacharyya, S.; Mukherjee, D. Synth. Commun. 1981, 11, 993.

192.Horwell, D. C; Howson, W.; Naylor, D.; Willems, H. M. G. Bioorg. Med. Chem. Lett. 1995, $5,1445$.

193.Abd El Samii, Zakaria K. M; Al Ashmawy, M. I., Mellor, J. M. J. Chem. Soc. Perkin Trans. $1, \mathbf{1 9 8 8}, 2523$.

194.Cuvigny, T.; Julia, M.; Rolando, C. J. Organometal. Chem. 1985, 285, 395.

195.Martin, C. J.; Rawson, D. J.; Williams, J. M. J. Tetrahedron:Asymmetry 1998, 9, 3723. 
196.Castelvetro, V.; Pittaluga, G. B.; Ciardelli, F. Macromol. Chem. Phys. 2001, 202, 2093.

197. Taylor, M. S.; Jacobsen, E. N. J. Am. Chem. Soc. 2003, 125, 11204.

198.Ohtake, N.; Yamada, K.; Mano, E.; Okamoto, O. Ushijma, R.; Nakagawa, S. J. Antibiotics 1997, 50, 567.

199.Sutherland, A. J.; Sutherland, J. K.; Crowley, P. J. J. Chem. Soc. Perkin Trans. 1 1996, 349.

200.Morales-Rios, M. S.; Bucio, M. A.; Garcia-Martinez, C.; Joseph-Nathan, P. Tetrahedron Lett. 1994, 35, 6087.

201. Suarez-Castillo, O. R.; Garcia-Velgara, M.; Morales-Rios, M. S.; Joseph-Nathan, P. Can. J. Chem. 1997, 75, 959.

202.Diker, K.; deMaindreville, M. D.; Levy, J. Tetrahedron Lett. 1995, 36, 3511.

203.Banziger, M.; Kusters, E.; La Vecchia, L.; Marterer, W.; Nozulak, J. Org. Process Res. Dev. 2003, 7, 904

204.Elkihel, L.; Bourass, J.; Dherbomez, M.; Letourneux, Y. Synth. Commun. 1997, 27, 1951.

205.Davis, A. P.; Egan, T. J.; Orchard, M. G.; Cunningham, D.; McArdle, P. Tetrahedron 1992, 48,8725 .

206. Robins, D. J. J. Chem. Research (S) 1983, 326.

207.Souchet, M.; Baillarge, M.; Le Goffic, F. Tetrahedron Lett. 1988, 29, 191.

208. Rousch, W. R.; Michaelides, M. R. Tetrahedron Lett. 1986, 27, 3353.

209.Plevey, R. G.; Sampson, P. J. Chem. Soc. Perkin Trans. 1 1987, 2129.

210.Babler, J. H.; Spina, K. P. Tetrahedron Lett. 1985, 26, 1923.

211.Babler, J. H.; Invergo, B. J. Tetrahedron Lett. 1981, 22, 2743.

212.Earl, H. A.; Stirling, C. J. M. J. Chem. Soc. Perkin Trans. 2 1987, 1273.

213. Stork, G.; Saccomano, N. A. Tetrahedron Lett. 1987, 28, 2087.

214. Chantigny, Y. A.; Dory, Y. L; Toro, A.; Deslongchamps, P. Can. J. Chem. 2002, 80, 875.

215.Hogan, I.; Jenkins, P. D.; Sainsbury, M. Tetrahedron 1990, 46, 2943.

216. Boeckman, R. K., Jr.; Ko, S. S. J. Am. Chem. Soc. 1982, 104, 1033.

217. Nasipuri, D.; Banerjee, S. J. Indian Chem. Soc. 1984, 61, 1038.

218. Blondet, D.; Morin, C. J. Chem. Soc. Perkin Trans. 1 1984, 1085.

219. Rowland, A. T.; Gill, B. C. J. Org. Chem. 1988, 53, 434.

220.Babler, J. H.; Spina, K. P. Tetrahedron Lett. 1983, 24, 3835.

221. Tanikaga, R.; Obata, Y.; Kawamoto, K.-I. Tetrahedron: Asymmetry 1997, 8, 3101.

222.Craig, D.; Henry, G. D. Tetrahedron Lett. 2005, 46, 2559.

223. Bladon, C. M.; Ferguson, I. E. G.; Kirby, G. W.; Lochead, A. W.; McDougall, D. C. J.

Chem. Soc. Perkin Trans. 1 1985, 1541.

224.Capobianco, M.; Mezzina, E.; Savoia, D.; Tagliavini, E.; Trombini, C. Umani-Ronchi, A. Tetrahedron Lett. 1986, 27, 1387.

225.Pearson, A. J.; Yoon, J. J. Chem. Soc. Chem. Commun. 1986, 1467.

226.(a) Kielbasinski, P.; Zurawinski, R.; Pietrusiewicz, K. M.; Zablocka, M.; Mikolajczyk, M.

Tetrahedron Lett. 1994, 35, 7081. (b) Kielbasinski, P.; Zurawinski, R.; Pietrusiewicz, K. M.;

Zablocka, M.; Mikolajczyk Polish J. Chem. 1998, 72, 564. 
227.Pietrusiewicz, K. M.; Zablocka, M; Monkiewicz, J. J. Org. Chem. 1984, 49, 1522.

228.Corbel, B.; L’Hostis-Kervella, I.; Haelters, J.-P. Synth. Commun. 1996, 26, 2561.

229.Peel, M. R.; Sternbach, D. D.; Johnson, M. R. J.Org. Chem. 1991, 56, 4990.

230.Pal, S.; Satyanarayana, G.O.S.; Bhattacharjee, G. Ghatak, U. R. Indian J. Chem. 1996, 35B, 286.

231.Sano, T.; Toda, J.; Kashiwaba, N.; Ohshima, T.; Tsuda, Y. Chem. Pharm. Bull. 1987, 35, 479.

232.Sano, T.; Inoue, H.; Ueda, T. Chem. Pharm. Bull. 1985, 33, 3595.

233.Deslongchamps, G.; Mink, D.; Boyle, P. D.; Singh, N. Can. J. Chem. 1994, 72, 1162. 


\section{Author}

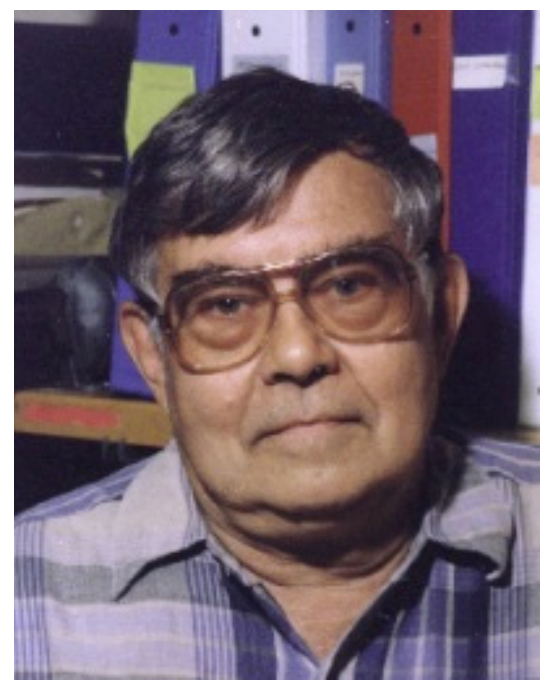

A. Paul Krapcho was born in Alden Station, PA on March 6, 1932. He did his undergraduate work at Penn State (B.S. in Chemistry, 1953) and graduate studies at Harvard University (Ph.D. 1957). He then spent the 2-year period of 1957-1959 teaching at Smith College and then held a post-doctoral position at Penn State from 1959-1960 (with Phil Skell). In 1960 he joined the faculty at the University of Vermont, where he is currently an Emeritus Professor of Chemistry still active in research. He has directed the research of numerous undergraduate and graduate students in projects related to natural product synthesis, solvolytic studies of spiro analogues, reaction mechanism studies of metal-ammonia reductions, chemistry of carbenes (or carbenoids), reactions of $\alpha$-anions of acids and esters, and the preparation of anticancer heterocyclic analogues. Krapcho has been a Fulbright scholar at the University of Montpellier, France (19681969), a research scholar at Stanford University (1976-1977) and an invited lecturer at Addis Ababa University in Ethiopia (1981). He was a research scholar at Duke University (1983-1984), the University research scholar in Physical Sciences (1990), a visiting Professor at the University of Auckland Medical School in Auckland, New Zealand (Spring 1991) and, for a short period, at Humboldt University in Berlin, Germany (1998). He has been involved over the past 15 years in a collaborative anticancer drug development program initially with the Vermont Cancer Center, and then with Novuspharma SpA of Milan, Italy (recently merged with CTI) and the University of Padova, Padova, Italy. These projects deal with the synthesis of telomerase inhibitors. Recently (2005-present) he was awarded a Dreyfus Senior Scientist Mentor grant. Krapcho is a Scientific Editor for ARKIVOC (2000-present) and a Co-Editor-in-Chief of Mini-Reviews in Medicinal Chemistry (2001-present). 